\title{
NEW AND NOTEWORTHY LICHEN-FORMING AND LICHENICOLOUS FUNGI, 11
}

\author{
S. Y. KondratyuK ${ }^{1}$, L. LőKös' ${ }^{2}$, S.-O. OH ${ }^{3}$, T. O. KondratiuK ${ }^{4}$ \\ I. Yu. PARNiKozA ${ }^{5,6}$ and J.-S. Hur ${ }^{7}$ \\ ${ }^{1}$ M. H. Kholodny Institute of Botany, Tereshchenkivska str. 2, 01004 Kiev, Ukraine \\ E-mail:ksya_net@ukr.net \\ ${ }^{2}$ Department of Botany, Hungarian Natural History Museum \\ H-1431 Budapest, Pf. 137, Hungary \\ ${ }^{3}$ Korea National Arboretum, Gwangneungsumogwon-ro 415, Pocheon-si \\ Gyeonggi-do 11186, Republic of Korea \\ ${ }^{4}$ ESC 'Institute of Biology and Medicine', Taras Shevchenko National University of Kyiv \\ Volodymyrska str. 64/13, Kyiv 01601, Ukraine \\ ${ }^{5}$ National Antarctic Scientific Centre of Ministry of Education and Science of Ukraine \\ Taras Shevchenko boulevard 16, Kyiv 01601, Ukraine \\ ${ }^{6}$ Institute of Molecular Biology and Genetics, NAS of Ukraine \\ Academician Zabolotny str. 150, Kyiv 03143, Ukraine \\ ${ }^{7}$ Korean Lichen Research Institute, Sunchon National University \\ Sunchon 540-742, Republic of Korea; E-mail: jshur1@sunchon.ac.kr
}

(Received 5 May, 2020; Accepted: 31 July, 2020)

Fourteen species new for science are described, illustrated and compared with closely related taxa. Six species of them are from South Korea, i.e. Bryostigma huriellae S. Y. Kondr. et J.-S. Hur, Caloplaca ulleungensis S. Y. Kondr., L. Lökös et J.-S. Hur, Enterographa dokdoensis S. Y. Kondr. et J.-S. Hur, Neobrownliella salyangensis S. Y. Kondr. et J.-S. Hur, Rufoplaca aesanensis S. Y. Kondr. et J.-S. Hur, Squamulea coreana S. Y. Kondr. et J.-S. Hur, and seven species are from Chile: Caloplaca nothocitrina S. Y. Kondr. et J.-S. Hur, Caloplaca nothoholocarpa S. Y. Kondr. et J.-S. Hur, Caloplaca patagoniensis S. Y. Kondr., S.-O. Oh et J.-S. Hur, Follmannia suborthoclada S. Y. Kondr. et J.-S. Hur, 'Lecidea' buellielloides S. Y. Kondr. et J.-S. Hur, Massjukiella rusavskioides S. Y. Kondr. et J.-S. Hur, Rehmanniella poeltiana S. Y. Kondr. et J.-S. Hur, as well as one species, i.e. Pyrenodesmia vernadskiensis S. Y. Kondr., T. O. Kondratiuk et I. Yu. Parnikoza, similar to Antarctic endemic species Huea coralligera, is from Argentine Islands, Western Antarctic Peninsula. The member of the genus Pyrenodesmia A. Massal. is for the first time confirmed by molecular data from the Antarctic.

Eighteen new combinations, i.e. Massjukiella impolita (for Caloplaca impolita Arup), Massjukiella pollinarioides (for Xanthoria pollinarioides L. Lindblom et D. M. Wright), Massjukiella stellata (for Caloplaca stellata Wetmore et Kärnefelt), Massjukiella tenax (for Xanthoria tenax L. Lindblom), and Massjukiella tenuiloba (for Xanthoria tenuiloba L. Lindblom), Pyrenodesmia albopruinosa (for Biatorina albopruinosa Arnold), Pyrenodesmia ceracea (for Caloplaca ceracea J. R. Laundon), Pyrenodesmia cretensis (for Blastenia cretensis Zahlbr.), Pyrenodesmia erythrocarpa (for Patellaria erythrocarpa Pers.), Pyrenodesmia haematites (for Lecanora haematites Chaub. ex St.-Amans), Pyrenodesmia percrocata (for Blastenia percrocata Arnold), Pyrenodesmia soralifera (for Caloplaca soralifera Vondrák et Hrouzek), Pyrenodesmia transcaspica (for Lecanora transcaspica Nyl.), Pyrenodesmia viridirufa (for Lecidea viridirufa Ach.), Pyrenodesmia xerica (for Caloplaca xerica Poelt et Vězda), as well as Rehmanniella leucoxantha (for Amphilo- 
ma leucoxanthum Müll. Arg.), Rehmanniella syvashica (for Caloplaca syvashica Khodos., Vondrák et Šoun), and Rehmanniella subgyalectoides (for Caloplaca subgyalectoides S. Y. Kondr. et Kärnefelt) are proposed.

Buelliella inops and Zwackhiomyces aff. berengerianus are for the first time recorded from South America as well as from Follmannia orthoclada (as lichenicolous fungi). Caloplaca poliotera, Rinodina convexula and Rinodina kozukensis are new to the Republic of Korea, and new localities as well as illustrations for the further 13 new and rare lichen species recently described from Eastern Asia are provided too.

Key words: Antarctica, Bryostigma, Caloplaca, Chile, Enterographa, Follmannia, Lecidea, Massjukiella, Neobrownliella, Pyrenodesmia, Rehmanniella, Rufoplaca, South America, South Korea, Squamulea

\section{INTRODUCTION}

A number of new-to-science species from eastern and southern Asia, i.e. South Korea and Japan, as well as from India were recently described and illustrated (Kondratyuk et al. 2016a, b, c, d, e, f, 2017a, b, 2018, 2019a, c). During our revision of the lichen collections of 2018-2019 deposited in KW-L and KoLRI several new species were found.

The status of some species is still being clarified and this communication is devoted to results of analysis of taxa of the genera Bryostigma, Caloplaca, Enterographa, Follmannia, Lecidea, Massjukiella, Neobrownliella, Pyrenodesmia, Rehmanniella, Rufoplaca, and Squamulea from the Asian, South American and the Antarctic continents, as well as to data on a few new taxa discovered within our comparative study during the revision of recent and previous collections kept in the KoLRI, KW-L, LWG and BP. The member of the genus Pyrenodesmia A. Massal. is for the first time confirmed for the Antarctica based on nrITS sequences.

\section{MATERIAL AND METHODS}

Revision of taxa listed below was based on herbarium specimens collected in previous years in Asia and South America and deposited in the herbaria KoLRI, BP, KW-L, as well as on fresh specimens from Antarctica collected during seasonal Antarctic Ukrainian expeditions in 2018 and 2020.

The specimens included in the comparative study were examined using standard microscopical techniques and hand-sectioned under a dissecting microscope (Nikon SMZ 645; Nikon, Tokyo, Japan). Anatomical descriptions were based on observations of these preparations under a microscope (Nikon Eclipse E200; Nikon, Tokyo, Japan, and Zeiss Scope, A1; Carl Zeiss, Oberkochen, Germany) with digital camera AxioCam ERc 5s. Section of apothecia were tested with water and with K and IKI (10\% aqueous potassium iodide) for identification. For identification of chemical substances of critical taxa standard TLC and HPTLC methods with solvent C were carried out (Arup et al. 1993, Orange et al. 2010). 


\section{RESULTS}

Bryostigma huriellae S. Y. Kondr. et J.-S. Hur, spec. nova

MycoBank No.: MB 836729

Similar to B. parietinaria and to B. dokdoense, but differs in causing much smaller infection spots, and in having smaller groups of ascomata, in having hyaline subhymenium and hyaline exciple in basal portion, in having narrower ascospores, in having mainly ascomata deeply immersed in thallus or fruiting bodies of host, as well as in having a different host.

Types: Republic of Korea, Gyeongsangnam-do, Pohang, Nam-gu, Guryongpo-eup, Guryongpo-ri, on siliceous seashore rock, on thallus and apothecia of Huriella pohangensis, killing specimens of host. Lat.: $35^{\circ} 59^{\prime} 39.36^{\prime \prime} \mathrm{N}$; Long.: $129^{\circ} 33^{\prime} 59.91^{\prime \prime}$ E; Alt.: $5 \mathrm{~m}$ a.s.l. Coll.: Kondratyuk, S. Y., Lőkös, L. (170195), 29.05.2017 (KoLRI 044319 sub Huriella - holotype); the same locality, (170196), (KoLRI 044320 sub Huriella - isotype).

Lichenicolous fungus forming very indistinct infection spots in host thallus and apothecia of Huriella pohangensis, and finally killing specimens of host lichen; infection spots often include very small, punctiform, scattered and distant ascomata or conidiomata.

Ascomata 70-90(-100) $\mu \mathrm{m}$ diam., and 50-55(-70) $\mu \mathrm{m}$ thick in section; mostly deeply immersed in thallus or fruiting bodies of host, aggregated in small groups (i.e. 1-3 per group), very indistinct (can be seen only at magnification $100 \times$ or more, or can be found in section of host thallus or apothecia), black; exciple dark brown-blackish at top and at sides (in $\mathrm{K}$ becoming dull greyish black, and brownish colour disappearing), while hyaline in basal portion; paraphysoids to $3 \mu \mathrm{m}$ diam., or slightly wider at tips to $3-4 \mu \mathrm{m}$ diam., somewhat curved above ascus tips; asci (15-)20-24 × (10-)12-15 $\mu \mathrm{m}$; ascospores hyaline becoming somewhat greyish with time, 1-septate, one cell slightly wider, $9-13 \times(3-) 3.5-5.5 \mu \mathrm{m}$, in water epispore very indistinct.

Etymology: It is named after host name, i.e. Huriella spp.

Distribution and ecology: It is so far known from South Korea, Eastern Asia. It grows in host thallus and apothecia of Huriella pohangensis, sometimes killing some specimens of host lichen.

Taxonomic notes: Bryostigma huriellae is similar to B. parietinarium (Hafellner et Fleischhacker) S. Y. Kondr. and to B. dokdoense (S. Y. Kondr., B. G. Lee, J. J. Woo et J.-S. Hur) S. Y. Kondr., but differs in causing much smaller infection spots, and in having smaller groups of ascomata (1-3 per group vs. to 5-10), in having hyaline subhymenium and hyaline exciple in basal portion (vs. pale brown or brown in basal portion in B. parietinarium), in having narrower ascospores $(9-13.5(-14) \times 3.5-4(-5) \mu \mathrm{m}$ vs. $(9-) 10-12(-13) \times(3-) 4-5 \mu \mathrm{m})$, in hav- 
ing mainly ascomata deeply immersed in thallus or fruiting bodies of host, as well as in having different host (Huriella spp. vs. Xanthoria and Orientophila spp.) (Kondratyuk et al. 2019d).

Caloplaca nothocitrina S. Y. Kondr. et J.-S. Hur, spec. nova (Fig. 1)

MycoBank No.: MB 836730

Similar to Flavoplaca citrina, but differs in having dispersed and distant areoles, in having biatorine apothecia, in having smaller soredia, in having oil cell in paraphyses and in having subhymenium with oil droplets, in having longer ascospores and in having narrower ascospore septum.

Types: Chile: Lago Balmaceda \& Lago Pinto, Patagonia (seaside), on rock, growing side by side with Caloplaca nothoholocarpa, and Gondwania sublobulata. Lat.: 51 $54^{\prime}$ 01.1" S; Long.: 72 ${ }^{\circ} 7^{\prime}$ 13.0" W; Alt.: ca 1 m a.s.1. Coll.: Oh, S.-O., Hur, J.-S. (CL130287), 20.01.2013 (KoLRI 017721 - holotype); the same locality, (CL130289), (KoLRI 017723 - isotype); the same locality, growing side by side with Caloplaca sp. 1, Caloplaca nothoholocarpa, and Buellia sp., (CL130288), (KoLRI 017722 - isotype); the same locality, growing together with Caloplaca nothoholocarpa, (CL130301), (KoLRI 017735 sub Caloplaca nothoholocarpa - isotype).

Thallus to $8 \mathrm{~mm}$ across, deep yellow and dull brownish yellow with somewhat brighter deep yellow apothecia; areolate and soredious; areoles very small, $0.2-0.3(-0.5) \mathrm{mm}$ diam./across, dispersed, often distant; soralia concave to $0.2-0.3 \mathrm{~mm}$ across; soredia $20-30 \mu \mathrm{m}$ diam., usually not numerous and do not form convex soredious mass. Hypothallus white.

Apothecia $0.4-0.7 \mathrm{~mm}$ diam., in section to $0.25 \mathrm{~mm}$ thick, with very thick thalline margin at first, to $0.1 \mathrm{~mm}$ thick, then margin becoming much thinner, to $0.05 \mathrm{~mm}$ wide, and less distant; margin bright yellow, disc dull dark yellowish or dull brownish yellow; in section biatorine, algae present only at the basis of apothecium, true exciple 30-40 $\mu \mathrm{m}$ thick in the uppermost lateral portion and to $40-70 \mu \mathrm{m}$ thick in lower lateral portions, with outer layer to 10-15 $\mu \mathrm{m}$ thick brownish orange, palisade type, of radiating hyphae, to $30-40(-70)$ $\mu \mathrm{m}$ thick in basal portion, scleroplectenchymatous, cell lumina 1.0-1.5 $\mu \mathrm{m}$ diam., hymenium to $70-80 \mu \mathrm{m}$ high; paraphyses to $4-5(-6) \mu \mathrm{m}$ diam. towards the tips, with oil cells to $5 \mu \mathrm{m}$ diam. and to $9 \mu \mathrm{m}$ long, often 2 cells in the same paraphyses present; subhymenium 50-60 $\mu$ m thick with oil droplets to 3(-8) $\mu \mathrm{m}$ diam.; asci 8-spored; ascospores rather long, fusiform with attenuated ends and widened at the septum, (12-)13-17 × (5.5-)6-7(-7.5) $\mu \mathrm{m}$ in water and $13-18(-19) \times(5.5-) 7-9 \mu \mathrm{m}$ in $\mathrm{K}$, septum $(2-) 3-4(-5) \mu \mathrm{m}$ wide in water, and (2.6-)3-7 $\mu \mathrm{m}$ wide in $\mathrm{K}$. 

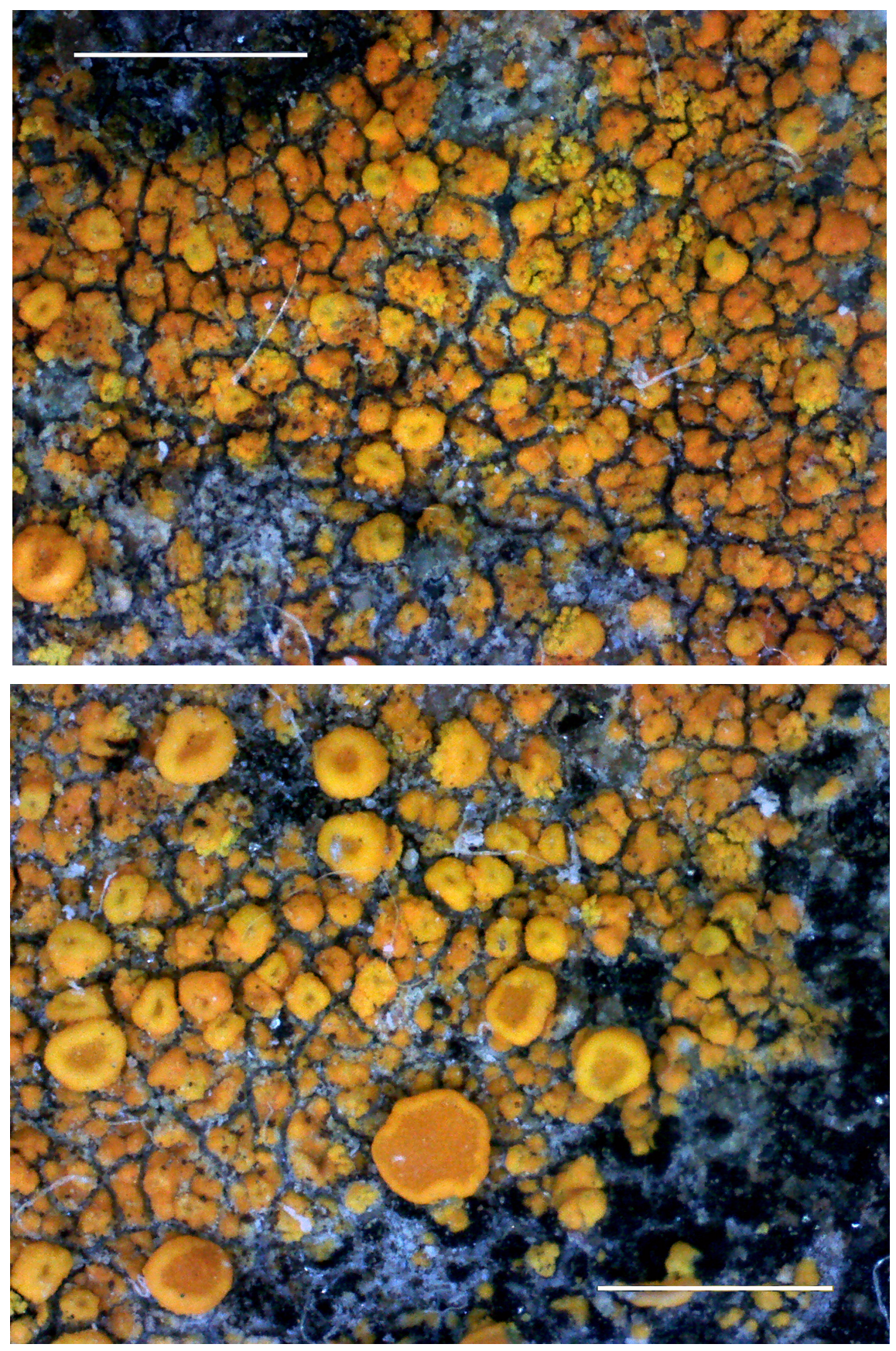

Fig. 1. Caloplaca nothocitrina (holotype), general habit. Scale $1 \mathrm{~mm}$ (photo: Kondratyuk, S. Y.) 
Chemistry: thallus, apothecia and soredia K+ purple.

Etymology: Species epithet reflects distribution of this lichen in the Southern Hemisphere and its similarity to the Northern Hemisphere species Flavoplaca citrina.

Distribution and ecology: So far known from type locality, Chile, South America. It grows on rocks in coastal areas, side by side with Caloplaca nothoholocarpa, Caloplaca sp., and Gondwania sublobulata (Nyl.) S. Y. Kondr. et al., and Buellia sp.

Taxonomic notes: This species is characterised by the presence of biatorine apothecia, the presence of oil paraphyses, and having long ascospores. Caloplaca nothocitrina is similar to Flavoplaca citrina (Hoffm.) Arup, Frödén et Søchting, but differs in having dispersed and distant areoles, in having biatorine apothecia, in having oil cells in paraphyses and in having subhymenium with oil droplets, in having smaller soredia (20-30 $\mu \mathrm{m}$ vs. (25-)30-60(-75) $\mu \mathrm{m})$, in having longer ascospores $((12-) 13-17 \times(5.5-) 6-7(-7.5) \mu \mathrm{m}$ vs. $(10-)$ 10.5-14.8(-15.2) × (4-)5-7.5(-8) um (Arup 2006)), in having somewhat narrower ascospore septum (3-4 $\mu \mathrm{m}$ vs. 3-5(-5.7) $\mu \mathrm{m}$ (Arup 2006)). Based on ascospore shape and measurements Caloplaca nothocitrina can be compared with Lazarenkoella polycarpoides (Eurasia), Xanthocarpia crenulatella (Northern Hemisphere) and X. jerramungupensis (Australia), but differs from all species in having soredious thallus. Caloplaca nothocitrina differs from Lazarenkoella polycarpoides (J. Steiner) S. Y. Kondr. et L. Lökös in having areolate thallus (vs. lobate), in having much smaller (0.4-0.7 mm vs. 0.4-1(-1.6) $\mathrm{mm}$ diam.) and biatorine apothecia, in having subhymenium with oil droplets, in having wider ascospore septum (3-4 $\mu \mathrm{m}$ vs. 2-3 $\mu \mathrm{m}$ wide), while ascospores are almost the same $((12-) 13-17 \times(5.5-) 6-7(-7.5) \mu \mathrm{m}$ vs. 11-19 × 5.5-7 $\mu \mathrm{m}$ (Steiner 1910)), as well as in different substrate (vs. bark of trees and on twigs of shrubs); $C$. nothocitrina differs from Xanthocarpia crenulatella (Nyl.) Frödén, Arup et Søchting in having white hypothallus, in having biatorine apothecia, in having thinner subhymenium with oil droplets, in having wider ascospore septum (3-4 $\mu \mathrm{m}$ vs. 1.5-3.5 $\mu \mathrm{m}$ wide), while ascospores are almost the same in these two species ((12-)13-17 × (5.5-)6-7(-7.5) $\mu \mathrm{m}$ vs. $(14-) 16-18(-20) \times(5-) 6-8(-9)$ $\mu \mathrm{m}) ;$ C. nothocitrina differs from Xanthocarpia jerramungupensis (S. Y. Kondr., Kärnefelt et Elix) S. Y. Kondr. et al. in having better developed (and soredious) thallus, in having bright deep yellow apothecia (vs. discs dull brownish orange to dark orange brown), in having narrower ascospores ((12-)13-17 $\times(5.5-) 6-7(-7.5) \mu \mathrm{m}$ vs. (13-)14-17 × (6-)7-9 $\mu \mathrm{m}$ as well as in having much wider ascospore septum (3-4 $\mu \mathrm{m}$ vs. (1.0-)1.5-2.0(-3.5) $\mu \mathrm{m}$ wide) (Kondratyuk et al. 2009a, 2013a). From growing side by side with Caloplaca nothoholocarpa $C$. nothocitrina differs in having much brighter yellow soredious thallus and bright yellow apothecia (while numerous dull brownish orange apothecia of C. nothoholocarpa form dull brownish orange colour of the whole thal- 
lus). Caloplaca nothocitrina is similar to C. cupulifera (Vain.) Zahlbr. in having very small almost indistinct soredia, widely distributed in tropical zone, but differs in having more yellowish orange thallus (vs. mostly greenish yellow or citrine yellow in C. cupulifera), as well as in having mainly scattered and thalline areoles distant from each other (vs. forming almost continuous thallus), in having larger soralia (to $0.2-0.3 \mathrm{~mm}$ across vs. $0.1-0.15(-0.2) \mathrm{mm}$ diam.), in having larger soredia (20-30 $\mu \mathrm{m}$ vs. $15-25 \mu \mathrm{m}$ diam.) and in its distribution (Kondratyuk et al. 2012). Caloplaca nothocitrina may resemble Flavoplaca flavocitrina (Nyl.) Arup, Frödén et Søchting, which usually has well-developed thalline areoles richly sorediate along the edges, but differs in having very scarce soredia, which do not form convex soredious mass. Furthermore, it differs from Flavoplaca flavocitrina in having biatorine apothecia, in having oil cells in paraphyses and in having subhymenium with oil droplets, in having longer ascospores (Arup 2006). This species is highly likely a member of the Flavoplaca branch of the Xanthorioideae too, however, this hypothesis will wait for confirmation by molecular data.

Caloplaca nothoholocarpa S. Y. Kondr. et J.-S. Hur, spec. nova (Fig. 2)

MycoBank No.: MB 836731

Similar to Athallia holocarpa, but differs in having very small apothecia, in having whitish hypothallus, in having longer ascospores and in having narrower ascospore septum.

Types: Chile: Lago Balmaceda \& Lago Pinto, Patagonia (seaside), on rock, growing together with Caloplaca sp. 1, and Caloplaca nothocitrina. Lat.: 51 $54^{\prime} 01.1^{\prime \prime}$ S; Long.: $72^{\circ} 27^{\prime}$ 13.0" W; Alt.: $1 \mathrm{~m}$ a.s.l. Coll.: Oh, S.-O., Hur, J.-S. (CL130289), 20.01.2013 (KoLRI 017723 holotype); the same locality, growing together with Caloplaca nothocitrina. Alt.: ca $1 \mathrm{~m}$ a.s.l. (CL130301), (KoLRI 017735 - isotype).

Thallus to $1.5-2 \mathrm{~cm}$ diam. or in much larger aggregations, greyish, whitish or whitish grey, but usually seems as dull orange or brownish orange of numerous apothecia; seems to be continuous or areolate (at high magnification $\times 50$ and more); areoles (0.2-)0.4-0.8 $\mathrm{mm}$ across (cracks to $0.04 \mathrm{~mm}$ wide), often indistinct and completely covered by apothecia to becoming exfoliating; upper surface whitish or whitish grey, with some yellowish spots or yellowish verrucae (highly likely of young apothecia), scattered and distant. Hypothallus whitish grey or white, usually well distinct.

Apothecia 0.15-0.4(-0.6) $\mathrm{mm}$ diam., in section to $0.12-0.2 \mathrm{~mm}$ thick, very numerous and usually aggregated, $2-4(-5)$ per areole, rounded or irregular, 

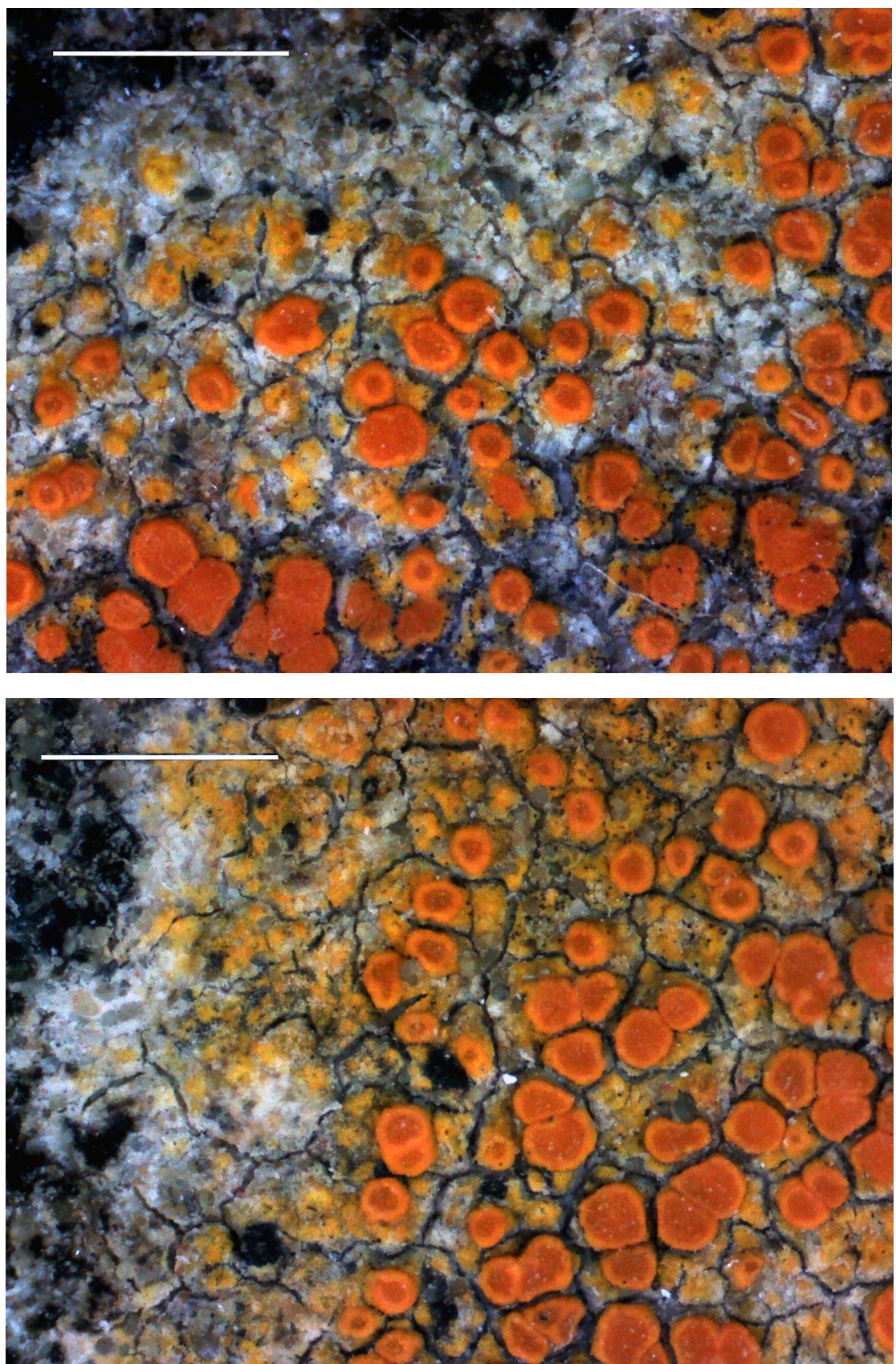

Fig. 2. Caloplaca nothoholocarpa (holotype), general habit. Scale 1 mm (photo: Kondratyuk, S. Y.) 
lecanorine or immersed into thallus at first, but soon / mostly biatorine and sessile, own margin very thin, to $0.04-0.05 \mathrm{~mm}$ wide, dull yellow or dull yellow-orange, while disc dull brownish yellow or dull brownish orange, plane; in section biatorine, thalline exciple absent; true exciple to 30-40 $\mu \mathrm{m}$ thick in both the uppermost and lower lateral portions with outer layer to 20-30 $\mu \mathrm{m}$ thick brownish orange or yellowish orange, to 15-20 $\mu \mathrm{m}$ thick in basal portion, paraplectenchymatous with matrix, cell lumina 3-4 $\mu \mathrm{m}$ diam.; algae present only at the basis of apothecium; hymenium 30-50(-75) $\mu \mathrm{m}$ high; paraphyses almost not swollen towards the tips to $3.5-4(-5) \mu \mathrm{m}$ diam.; subhymenium rather thin, to $30(-40) \mu \mathrm{m}$ thick, with numerous oil droplets to 5-6 $\mu \mathrm{m}$ diam. and irregular oil agglomerations to $4-7 \mu \mathrm{m}$ across; asci (4-)8-spored, where 4 bipolar and 4 simple abortive spores seen; ascospores fusiform, ends somewhat attenuated, slightly widened at the equatorial part, (12-)13-15 × (5-)6-8 $\mu \mathrm{m}$ in water and becoming much wider to (12-)13-14(-15) $\times(7-) 8-10 \mu \mathrm{m}$ in $\mathrm{K}$; ascospore septum 2.5-3.5(-4) $\mu \mathrm{m}$ wide in water and 4-5(-6) $\mu \mathrm{m}$ in $\mathrm{K}$.

Chemistry: Epihymenium $\mathrm{K}+$ purple or somewhat blackish purple in places, then becoming crimson.

Etymology: Species epithet reflects distribution of this lichen in the Southern Hemisphere and its similarity to the Northern Hemisphere species Athallia holocarpa.

Distribution: So far known only from two localities in Chile, South America.

Taxonomic notes: Caloplaca nothoholocarpa is similar to Athallia holocarpa (Hoffm.) Arup, Frödén et Søchting, but differs in having very small apothecia, in having whitish hypothallus, in having longer ascospores $(13-15 \times 6-8 \mu \mathrm{m}$ vs. $10-13 \times 6-8 \mu \mathrm{m})$ and in having somewhat narrower ascospore septum (2.5-3.5 $\mu \mathrm{m}$ vs. 3-6 $\mu \mathrm{m}$ wide). So far Øvstedal and Lewis Smith (2001) mentioned convex and very large (up to $1.3 \mathrm{~mm}$ diam.) apothecia as diagnostic character of the Southern Hemisphere material of 'Caloplaca holocarpa', material of $C$. nothoholocarpa can be keyed only to Gondwania sublobulata (Nyl.) S. Y. Kondr. et al., and Austroplaca johnstonii (C. W. Dodge) Søchting, Frödén et Arup or Caloplaca schofieldii C. W. Dodge, all of which are very different from the above-described species. Furthermore, after Øvstedal and Lewis Smith (2001) 'Caloplaca holocarpa' is characterised by hypothecium without oil droplets and much wider ascospores (14-16 $\times 11-12 \mu \mathrm{m})$. It is undoubtedly different material from Caloplaca nothoholocarpa described here, too. This species is highly likely a member of the Athallia branch of the Xanthorioideae too, however, this hypothesis will have to wait for confirmation by molecular data. 
Caloplaca patagoniensis S. Y. Kondr., S.-O. Oh et J.-S. Hur, spec. nova (Fig. 3)

MycoBank No.: MB 836732

Similar to Flavoplaca kantvilasii, but differs in having much larger thallus, in having smaller areoles, in having narrower thalline and true exciple, in having wider ascospores, in having smaller blastidia and conblastidia, as well as in having another substrate.

Type: Chile, Patagonia, Torres del Paine, Y290 10-15 km, on dead tree, growing to-

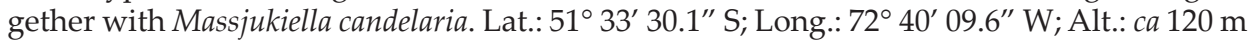
a.s.1. Coll.: Oh, S.-O., Hur, J.-S. (CL130091), 17.01.2013 (KoLRI 017520 - holotype).

Thallus 2-9 mm across, but usually aggregated in much larger aggregations, distinctly areolate, areoles to $0.6 \mathrm{~mm}$ across, at first whitish to whitish or greyish yellow and only blastidia seen from a few sides which differs in much brighter deep orange colour to dark brownish orange or dull brownish yellow, blastidious mass deeply orange, conidiomata and apothecia dark dull reddish orange. Areoles $0.2-0.6(-0.8)[-1] \mathrm{mm}$ across to $(0.1-) 0.25-0.4(-0.6) \mathrm{mm}$ high/ thick, especially in the centre, where they almost completely covered by blastidious mass. Soredia/blastidia 20-25(-30) $\mu \mathrm{m}$ diam., with brownish orange surface (i.e. blastidia type after Poelt and Petutschnig 1992), conblastidia to 40-50(-65) $\mu \mathrm{m}$ diam./across, consisting of several blastidia. Thallus in section with very narrow cortical layer, to 5-7 $\mu \mathrm{m}$ thick, paraplectenchymatous, cell lumina 4-5 $\mu \mathrm{m}$ across, cells elongated along the surface of the areoles, with distinct to $10 \mu \mathrm{m}$ thick, somewhat greyish, epinecral layer.

Apothecia (0.2-)0.3-0.6 mm diam. (and to 0.2-0.25 mm thick in section), at first immersed into substrate, then somewhat immersed into sorediateblastidiate mass, zeorine at first (disc dark reddish-brownish orange, true exciple slightly lighter than disc, reddish-brownish orange and thalline exciple dull brownish yellow or brownish green yellow), then usually thalline exciple completely blastidiate, disc concave to plane; in section true exciple 25-40 $\mu \mathrm{m}$ thick in the uppermost lateral portion, to 30-40 $\mu \mathrm{m}$ thick in lower lateral portion, pseudoprosoplectenchymatous, 20-30 $\mu \mathrm{m}$ thick in basal portion, paraplectenchymatous with distinct matrix, cell lumina 4-5 $\mu \mathrm{m}$ diam./ across, thalline exciple (if present, i.e. not dissolved into soredia/blastidia), to 50-70 $\mu \mathrm{m}$ thick; algal zone often with oil cells seen in water (better seen in $\mathrm{K}$ ); hymenium 80-100 $\mu \mathrm{m}$ high, paraphyses distinctly swollen towards the tips, to 6-7 $\mu \mathrm{m}$ diam.; subhymenium to $30 \mu \mathrm{m}$ thick; asci 8-spored, with variegated ascospores in the same ascus, usually 4-6 larger and 2-4 smaller bipolar ascospores; ascospores widely ellipsoid to somewhat elongated (9-)11-15(-16) $\times(5-) 7-8 \mu \mathrm{m}$ in water and (8-)11-16(-17) $\times(5-) 7-9(-10) \mu \mathrm{m}$ in $\mathrm{K}$; ascospore 

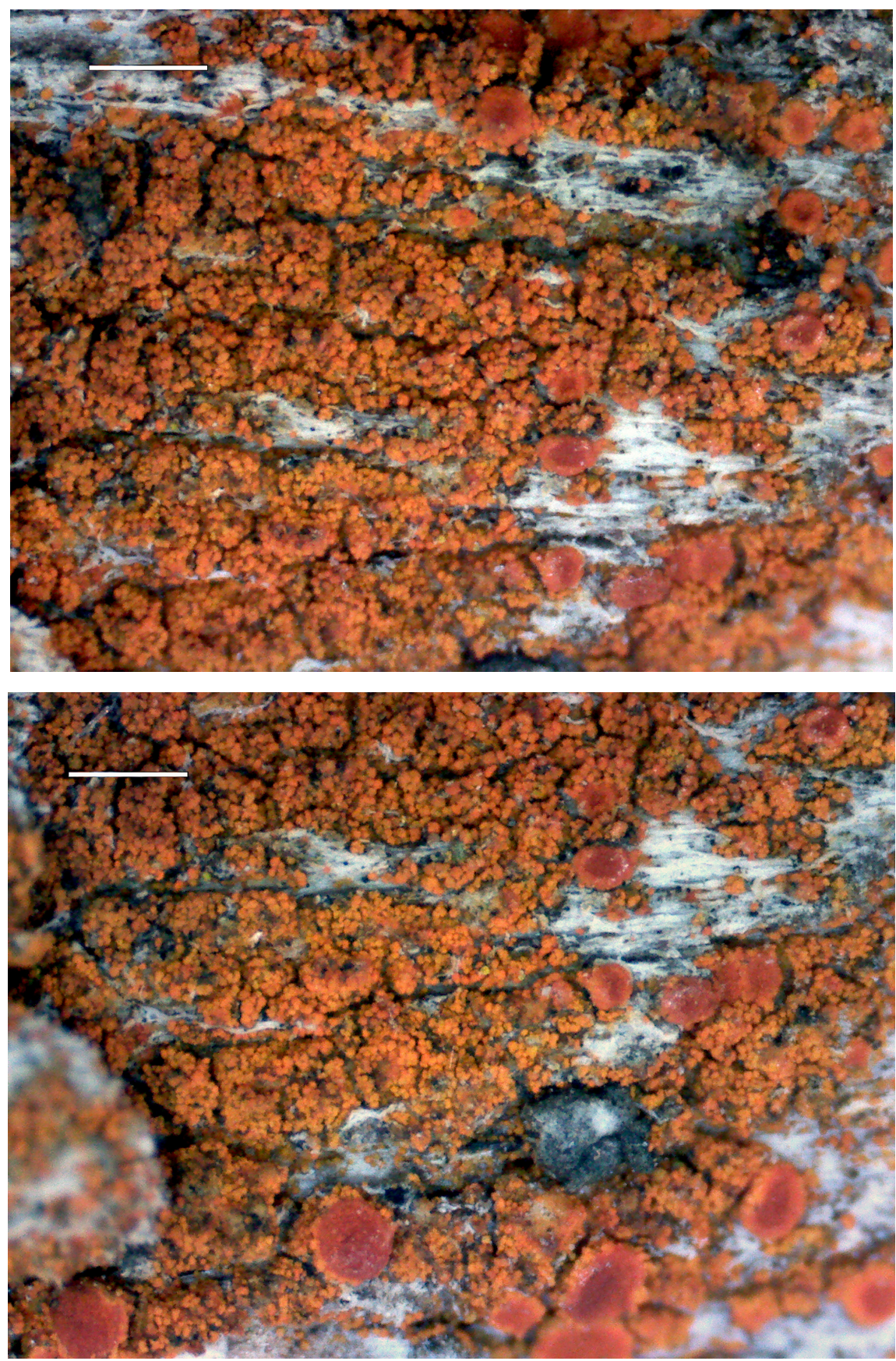

Fig. 3. Caloplaca patagoniensis (holotype), general habit. Scale $0.5 \mathrm{~mm}$ (photo: Kondratyuk, S. Y.) 
septum 3-5(-7) $\mu \mathrm{m}$ wide in water and (3-)6-8 $\mu \mathrm{m}$ wide in K. Conidiomata dull reddish orange, common and numerous. Conidia narrowly bacilliform to widely ellipsoid, $2.5-3 \times 0.8-1.2 \mu \mathrm{m}$.

Chemistry: Thallus, apothecia and conidiomata $\mathrm{K}+$ purple; epihymenium $\mathrm{K}+$ somewhat blackish purple then becoming crimson purple. Parietin present.

Distribution and ecology: So far known from the type collection from Chile, South America. It grows on dead wood, where it was associated with Massjukiella candelaria aggr. and Lecidella sp. and other crustose lichens.

Etymology: It is named after type locality, i.e. Patagonia, Chile, South America.

Taxonomic notes: Caloplaca patagoniensis is similar to the Australian Flavoplaca kantvilasii (S. Y. Kondr. et Kärnefelt) Arup, Frödén et Søchting by having a somewhat concave upper surface of lobe areoles being extremely richly blastidious/soredious at the lower lateral portions, but differs in having a much larger thallus (2-9 mm vs. $1-4 \mathrm{~mm}$ across), in having smaller areoles (0.2-0.6 $\mathrm{mm}$ vs. $0.5-1.8 \mathrm{~mm}$ across), in having narrower thalline and true exciple, in having wider ascospores (7-8 $\mu \mathrm{m}$ vs. $5-7 \mu \mathrm{m}$ wide), in having somewhat smaller blastidia $(20-25 \mu \mathrm{m}$ vs. $25-35 \mu \mathrm{m})$, and in having smaller conblastidia (40-50 $\mu \mathrm{m}$ vs. 55-70 $\mu \mathrm{m}$ diam./across), as well as in growing on wooden substrate (vs. siliceous and calcareous rocks) (Kondratyuk et al. 2007). Caloplaca patagoniensis is similar to the widely distributed Flavoplaca flavocitrina (Nyl.) Arup, Frödén et Søchting, especially after having soredious/blastidious mass covering to $70-100 \%$ of the surface of the areoles. However, it can be distinguished from $F$. citrina by very thick and convex areoles, by the smaller blastidia (20-25 $\mu \mathrm{m}$ vs. $20-40 \mu \mathrm{m}$ diam.), by the larger conblastidia, and by the wider ascospores (7-8 $\mu \mathrm{m}$ vs. 5-7 $\mu \mathrm{m}$ wide), as well as the lack of whitish hypothallus (Arup 2006).

Caloplaca ulleungensis S. Y. Kondr., L. Lőkös et J.-S. Hur, spec. nova (Fig. 4)

MycoBank No.: MB 836733

Similar to Caloplaca kedrovopadensis, but differs in having larger apothecia, in having paraplectenchymatous true exciple, in having higher hymenium, in having thicker subhymenium, in having longer ascospores and wider ascospore septum.

Types: Republic of Korea, Gyeongsangbuk-do, Ulleung-gun, Ulleung-eup, Jeodongri, along path to Bongrae waterfall, on rock wall. Lat.: $37^{\circ} 29^{\prime} 52.10^{\prime \prime}$ N; Long.: $130^{\circ} 53^{\prime} 19.72^{\prime \prime}$ E; Alt.: 285 m a.s.l. Coll.: Kondratyuk, S. Y., Lőkös, L. (161544), 09.07.2016 (KoLRI 039762 - holotype); the same locality, (161537, 161547) (KoLRI 039755, KoLRI 039765 - isotypes). 
Thallus crustose overgrowing rock surface, as well as bryophyte thalli and the plant remnants, dull yellowish or greyish or whitish grey in places; upper surface cracked, but cracks very narrow (to 20(-35) $\mu \mathrm{m}$ wide) and rock surface not seen at $120 \times$, cracked into very small portions, $0.1-0.3 \mathrm{~mm}$ across and very uneven (shagreen-like), any vegetative propagules (like in Caloplaca coreana) absent. Black line along thallus edge to $0.1-0.2 \mathrm{~mm}$ wide present.

Apothecia (0.2-)0.4-0.7(-1.1) mm diam., and to 0.3-0.35 mm thick in section, disc dark brown, own margin dull yellow or dull yellow-orange, Brigantiaea- or Letrouitia-type; thalline/own margin to (0.06-)0.1-0.15 mm wide usually rising above the level of disc and folded above disc, more or less persistent, disc plane to waving/undulating; apothecia mostly scattered, distant and regularly rounded especially at the beginning, in older apothecia the margin sometimes waved; in section biatorine (algae seen at the basis of apothecium); true exciple to $40-50(-100) \mu \mathrm{m}$ wide, brownish orange in outermost half of outermost lateral portion, palisade paraplectenchymatous, outer layer of radiating lines of cells, in the inner portion, 50-70(-90) $\mu \mathrm{m}$ wide in lower lateral portion, and 70-100 $\mu \mathrm{m}$ thick in basal portion, paraplectenchymatous, cell lumina 5-8 $\mu \mathrm{m}$ across; hymenium (100-)120-160(-180) $\mu \mathrm{m}$ high, with oil especially in lower portion; epihymenium dark brown to $40-50 \mu \mathrm{m}$ thick; paraphyses to 2.0-2.5 $\mu \mathrm{m}$ wide not swollen towards the tips (to 3-4 $\mu \mathrm{m}$ wide in $\mathrm{K}$ ); subhymenium 70-120(-130) $\mu \mathrm{m}$ thick, somewhat greyish or yellowish, with oil droplets (rarely without oil); asci (70-)80-90 × 21-22(-24) $\mu \mathrm{m},(4-) 8$-spored, often with 2-4 bipolar and other hyaline single or 1-septate ascospores, often with 1 to 4 brownish or yellowish ascospores with 4 abortive single and much smaller ascospores (similarly to Xanthocarpia jerramungupensis); ascospores fusiform with attenuated ends, often becoming yellowish, orange or brownish, very rarely with 2 or 3 septa, (15-)19-25(-28) $\times(7-) 10-12(-13) \mu \mathrm{m}$ in water $(\mathrm{n}=75)$ and $(15-) 18-29(-32) \times(6-) 10-13(-14) \mu \mathrm{m}$ in $\mathrm{K}(\mathrm{n}=78)$, wall of ascospores to $1.5-1.8(-2.0) \mu \mathrm{m}$ thick in $\mathrm{K}$; ascospore septum very variable in thickness from one to another ascospore as within ascus, as within section, $(1-) 3-6(-8) \mu \mathrm{m}$ wide in water and (1-)4-10(-13) $\mu \mathrm{m}$ wide in K. Conidia bacilliform 2.6-3 × 1.0-1.1 $\mu \mathrm{m}$.

Etymology: It is named after the type locality, i.e. Ulleung-do Island, Republic of Korea, Eastern Asia.

Distribution and ecology: So far known from several localities, i.e. Ulleung-do and Jeju-do Islands, South Korea, Eastern Asia. It grows on siliceous rock.

Taxonomic notes: Caloplaca ulleungensis is similar to the Eastern Asian Caloplaca kedrovopadensis S. Y. Kondr. et J.-S. Hur in growing on siliceous rocks, but differs in having larger apothecia $(0.4-0.7(-1) \mathrm{mm}$ vs. $0.3-0.4(-0.55)$ $\mathrm{mm})$, in having paraplectenchymatous true exciple (vs. of Blastenia-type), in 

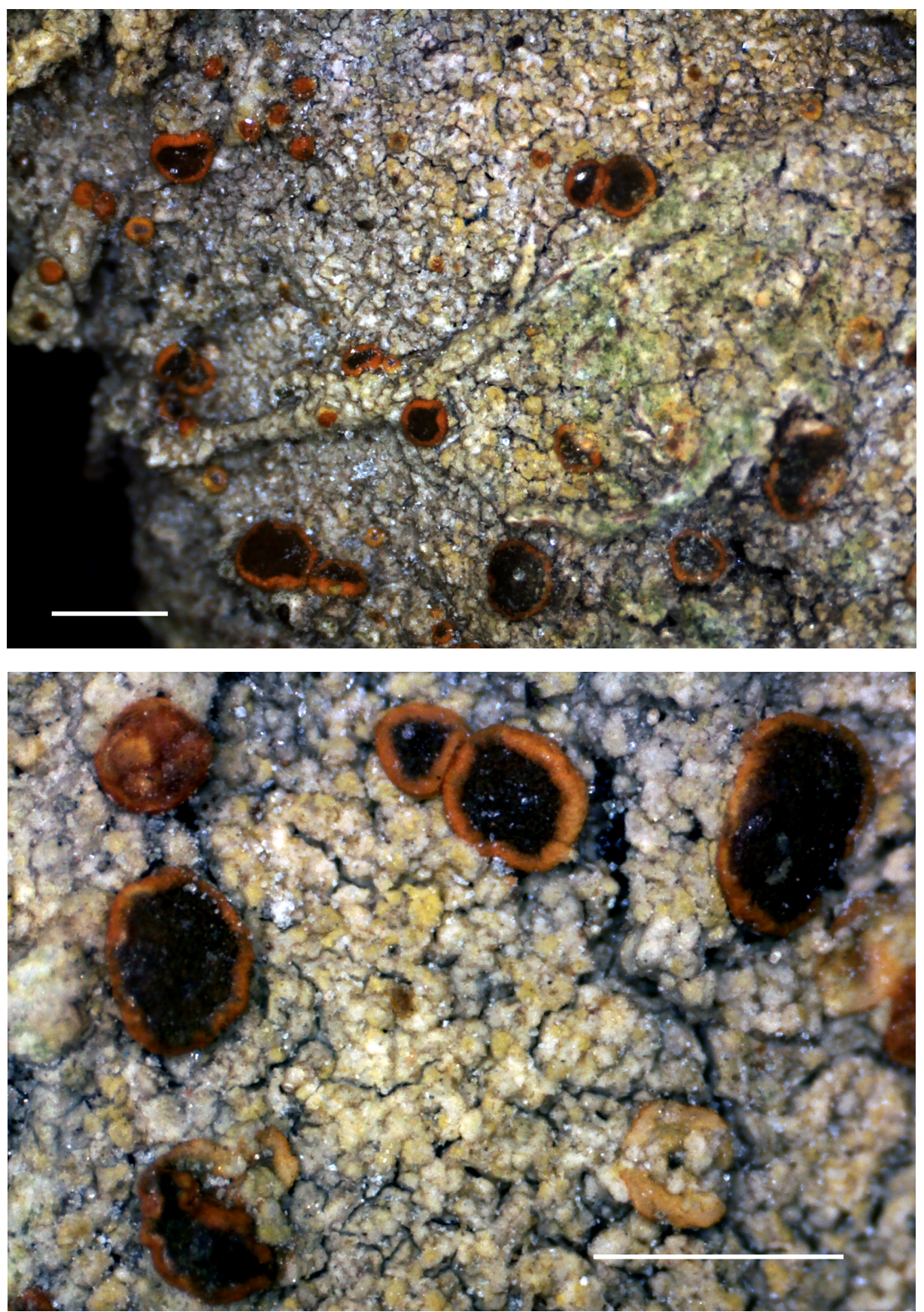

Fig. 4. Caloplaca ulleungensis (151568, holotype), general habit. Scale $1 \mathrm{~mm}$ (photo: Kondratyuk, S. Y.) 
having higher hymenium (160-180 $\mu \mathrm{m}$ vs. (70-)80-100 $\mu \mathrm{m}$ high), in having thicker subhymenium (70-80 $\mu \mathrm{m}$ vs. to $30 \mu \mathrm{m}$ thick), in having longer and wider ascospores $((15-) 19-25(-28) \times(7-) 10-12(-13) \mu \mathrm{m}$ vs. $(19-) 20-23(-26) \times$ $8.5-10 \mu \mathrm{m}$ in water and (15-)18-29(-32) × (6-)10-13(-14) $\mu \mathrm{m}$ vs. $(14-) 17-20 \times$ (7.5-)8-10(-11) $\mu \mathrm{m}$ in $\mathrm{K})$, and wider ascospore septum $((1-) 3-6(-8) \mu \mathrm{m}$ wide vs. $2-4(-5) \mu \mathrm{m}$ in water and (1-)4-10(-13) $\mu \mathrm{m}$ wide vs. (4-)5-7(-9) $\mu \mathrm{m}$ in $\mathrm{K})$ (Kondratyuk et al. 2014b). Caloplaca ulleungensis is similar to another Eastern Asian lichen species C. fusanii (Hue) Zahlbr. known from Republic of Korea and Japan, but differs in having longer and narrower ascospores ((15-)19$25(-28) \times(7-) 10-12(-13) \mu \mathrm{m}$ vs. $22-24 \times 12-14 \mu \mathrm{m})$, and having rather wider ascospore septum $((1-) 3-6(-8) \mu \mathrm{m}$ wide in water and (1-)4-10(-13) $\mu \mathrm{m}$ wide in K vs. these data not mentioned in Hue's original description) (Hue 1915a). Caloplaca ulleungensis is similar to the Western Australian terricolous (growing on sandy soil) Xanthocarpia jerramungupensis, but differs in having much better developed true exciple in basal portion (70-100 $\mu \mathrm{m}$ vs. $20-25 \mu \mathrm{m}$ thick), in having higher hymenium (160-170 $\mu \mathrm{m}$ vs. 80-90 $\mu \mathrm{m})$, in having much longer and wider ascospores $((15-) 19-25(-28) \times(7-) 10-12(-13) \mu \mathrm{m}$ vs. $(13-) 14-17 \times$ $(6-) 7-9 \mu \mathrm{m}$ in water and (15-)18-29(-32) $\times(6-) 10-13(-14) \mu \mathrm{m}$ vs. (12-)13-17 $(-18) \times 7-9(-10) \mu \mathrm{m}$ in $\mathrm{K})$, and wider ascospore septum $((1-) 3-6(-8) \mu \mathrm{m}$ wide vs. (1.0-)1.5-2.0(-3.5) $\mu \mathrm{m}$ in water and (1-)4-10(-13) $\mu \mathrm{m}$ wide vs. (2-)3-4(-5) $\mu \mathrm{m}$ in K) (Kondratyuk et al. 2009a, 2014c). Caloplaca ulleungensis is similar to species of the genera Brigantiaea or Letrouitia in seeming to be biatorine apothecia with dark brown disc and dull yellow or dull yellow-orange margin, but differs in having (4-)8-spored asci and bipolar ascospores.

Other specimens examined: Republic of Korea, Jeju-do, Seogwipo-si, Mt Halla (Yeongsil Trail), on rock. Lat.: $33^{\circ} 21^{\prime} 16.27^{\prime \prime} \mathrm{N}$; Long.: $126^{\circ} 29^{\prime} 57.64^{\prime}$ E; Alt.: 1,337 m a.s.l. Coll.: Halda, J. (151568), 21.07.2015 (KoLRI 035261).

Enterographa dokdoensis S. Y. Kondr., L. Lőkös, B. G. Lee et J.-S. Hur, spec. nova

(Fig. 5)

MycoBank No.: MB 836734

Similar to Enterographa leucolyta, but differs in having narrower ascospores and shorter conidia.

Types: Republic of Korea, Dokdo Islands, Eastern (Dokdo) Island, seashore, left side of dock, on rocks growing together with Opegrapha ulleungdoensis. Lat.: $37^{\circ} 14^{\prime} 23^{\prime \prime} \mathrm{N}$; Long.: 131 52' 6.41" E; Alt.: 5 m a.s.1. Coll.: Lee, B. G. (170972), 08.09.2017 (KoLRI 045253 sub Enterographa - holotype); the same locality, growing together with Opegrapha ulleungdoensis, (170964, 170965, 171005, 171006, 171007), (KoLRI 045245, KoLRI 045246, KoLRI 045286, 
KoLRI 045287, KoLRI 045288 sub Opegrapha ulleungdoensis - isotypes); the same locality, growing together with Opegrapha ulleungdoensis, (170973, 170974, 170975, 170976, 170977, 170997) (KoLRI 045254, KoLRI 045255, KoLRI 045256, KoLRI 045257, KoLRI 045258, KoLRI 045278 sub Enterographa - isotypes); the same locality, (170999), (KoLRI 045280 sub Enterographa - isotype, DNA voucher SK L18); the same locality, growing together with Opegrapha ulleungdoensis, (171000), (KoLRI 045281 sub Enterographa - isotype, DNA voucher SK L19); the same locality, growing together with Aspicilia sp., (171001), (KoLRI $045282 \mathrm{sub}$ Enterographa - isotype); the same locality, growing together with Opegrapha ulleungdoensis, Aspicilia sp. (170963), (KoLRI 045244 sub Opegrapha ulleungdoensis - isotype, DNA voucher SK L17); the same locality, growing together with Opegrapha ulleungdoensis, Orientophila dodongensis, (170971), (KoLRI 045252 sub Orientophila dodongensis - isotype).

Thallus up to 5-10 $\mathrm{cm}$ in diam. or more, covering large areas, smooth to verrucose, green-grey to mauve coloured, water-absorbing, to $200 \mu \mathrm{m}$ thick, sometimes with soredious spots*; photobiont Trentepohlia, algal cells 6.4-9.6 $\mu \mathrm{m}$ diam.; hypothallus indistinct or absent.

Ascomata open, shortly lirelline and branched, $0.1-0.2 \times 0.2-1.2 \mathrm{~mm}$, rarely ellipsoid, not in stroma, disc mostly pale brown, rarely to dark brownish, not pruinose. Thalline margin to $32-40(-50) \mu \mathrm{m}$ wide; exciple very thin, $12-20$ $\mu \mathrm{m}$ wide, more or less pale or yellowish; hypothecium hyaline, $25-50 \mu \mathrm{m}$ tall, $\mathrm{K}-$. Hymenium hyaline, 50-60 $\mu \mathrm{m}$ high. Paraphysoids 0.8-1.0 mm wide, apices to $\mathrm{ca} 15 \mu \mathrm{m}$ wide, branched and anastomosed especially in the upper part. Epihymenium to 2-5 $\mu \mathrm{m}$ thick, with yellowish crystals of 2-5 $\mu \mathrm{m}$ diam./across, K-. Asci cylindrical, 8-spored; ascospores fusiform, not curved, (1-)3-5-septate, with more or less thin perispore, 20.8-27.2(-30.4) $\times(1.6-) 1.9-3.0(-3.5) \mu \mathrm{m}$. Conidiomata punctiform, to $0.1 \mathrm{~mm}$ diam., immersed, yellowish or brownish, wall pale yellowish in section, conidia filiform and curved, 12-16(-20) $\times 0.8 \mu \mathrm{m}$.

Chemistry: Thallus $\mathrm{C}+$ red, $\mathrm{K}-, \mathrm{PD}-, \mathrm{UV}+$ pale cream; gyrophoric acid present.

Etymology: It is named after the type collection, Dokdo (Eastern) Island of the Dokdo Islands, South Korea, Eastern Asia.

Distribution and ecology: It is so far known from several localities in South Korea, Eastern Asia. It grows mostly on vertical surfaces of siliceous rocks in coastal conditions.

Taxonomic notes: Enterographa dokdoensis is similar to E. leucolyta (Nyl.) Redinger, a pantropical species, growing on coastal volcanic rocks, typically on vertical, shaded rock faces, but differs in having lower hymenium (50-60 $\mu \mathrm{m}$ vs. $120 \mu \mathrm{m}$ high), in having somewhat narrower and longer ascospores (20-27 $(-30.5) \times(1.6-) 1.9-3(-3.5) \mu \mathrm{m}$ vs. 18-25(-27) $\times 2.5-3(-4) \mu \mathrm{m})$, and in having shorter conidia (12-16(-20) $\mu \mathrm{m}$ vs. 20-25 $\mu \mathrm{m}$ long) (cf. Sparrius 2004). One of the previous records of Enterographa leucolyta from South Korea, Geumoh-do

\footnotetext{
* Status of soredious specimens of Enterographa dokdoensis (see specimens 170963, 171077, etc.) should be clarified additionally with future larger collections.
} 

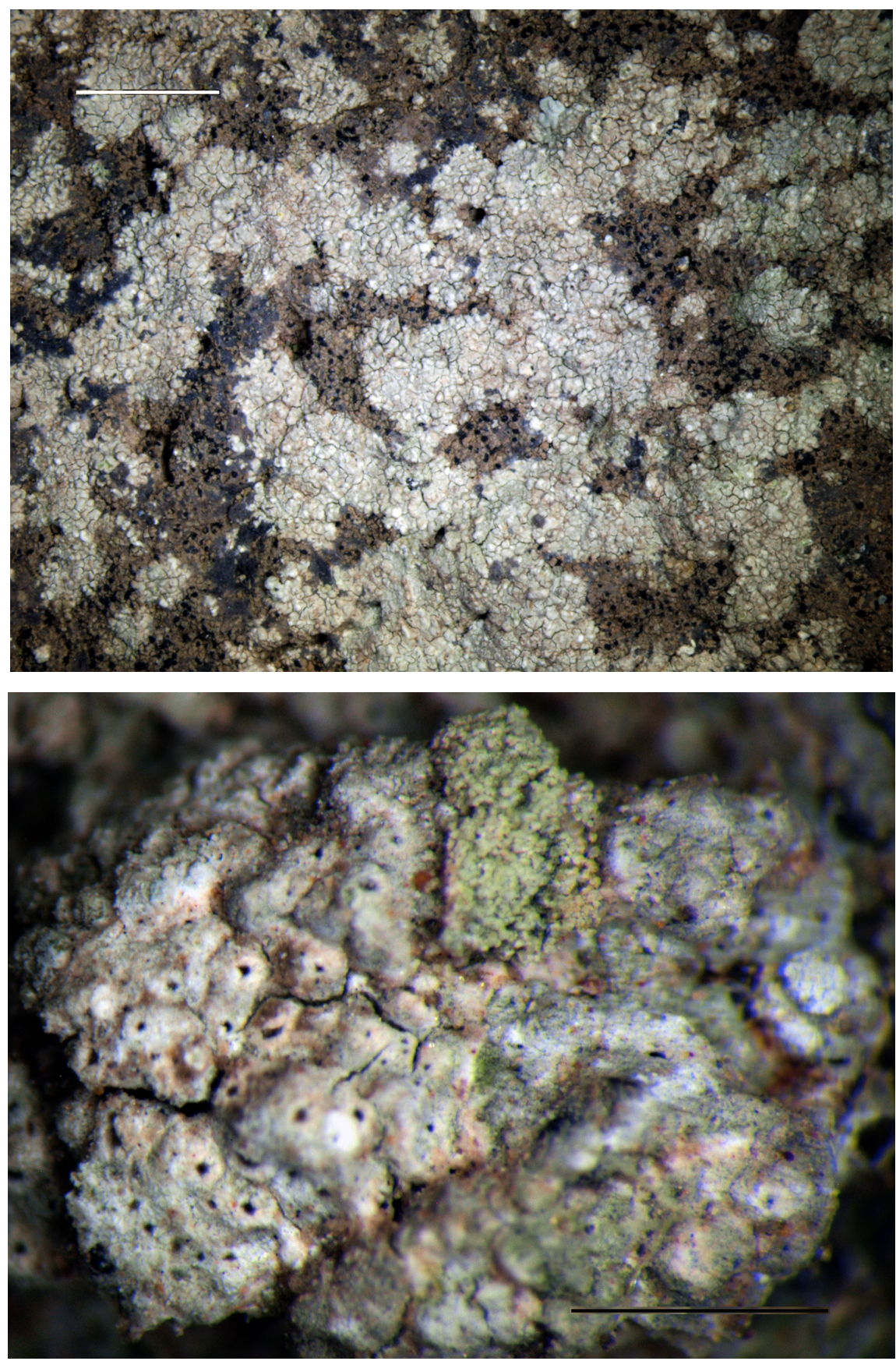

Fig. 5. Enterographa dokdoensis (170972, holotype), general habit. Scale 1 mm (photo: Kondratyuk, S. Y.) 
Island (Joshi et al. 2013: 180) may belong to this species, too. However, data on conidia of those specimens were not mentioned and that species differs from diagnosis of E. leucolyta in having much higher hymenium (120-130 vs. 55-100 $\mu \mathrm{m}$ ), also incorrect data on thalline margin are provided. Enterographa dokdoensis is similar to the Australian epiphytic species E. divergens (Müll. Arg.) Redinger in having very thin, smooth or slightly wrinkled thallus, as well as after nrITS phylogeny, but differs in having light whitish grey thallus (vs. brownish grey), in having indistinct apothecia (vs. very numerous, immersed, at first punctiform, then elliptical, elongated, curved, to $1 \mathrm{~mm}$ long and $0.13 \mathrm{~mm}$ wide), in having light brown disc (vs. black disc), and in having shorter and narrower, (1-)3-5-septate ascospores (20.8-27.2(-30.4) × (1.6-)1.93(-3.5) $\mu \mathrm{m}$ vs. $24-32 \times 3-4 \mu \mathrm{m}, 7$-septate). Enterographa dokdoensis is similar to E. praepallens ( $\mathrm{Nyl}$.) Redinger known from andesitic rock in Japan, but differs in having thinner whitish grey thallus (vs. 100-150 $\mu \mathrm{m}$ thick, grey to yellowish white or $\mathrm{K}+$ ochre yellow), in having indistinct apothecia (vs. $1.5 \mathrm{~mm}$ long to $0.16-0.2 \mathrm{~mm}$ wide, variously twisted, simple or sometimes forked), in having light brown disc (vs. disc ochre yellow), in having lower hymenium (vs. $100 \mu \mathrm{m}$ high), while ascospores are almost the same (ascospores not seen by Nylander, but based on Redinger, 20-23 × $3 \mu \mathrm{m}$, 5-?-septate) (cf. Redinger 1938). Enterographa dokdoensis is similar to E. anguinella (Nyl.) Redinger known from Japan and Philippines, but differs in having matt whitish grey thallus (vs. grey to light ochre, slightly shiny, $\mathrm{K}+$ ochre brown), in having indistinct apothecia (vs. numerous, immersed to $1.5(-2.8) \mathrm{mm}$ long), and in having shorter and narrower, (1-)3-5-septate ascospores (20.8-27.2(-30.4) $\times(1.6-) 1.9-$ $3.0(-3.5) \mu \mathrm{m}$ vs. (22-)31-38 × 3-4 $\mu \mathrm{m}, 7-9$-septate) (cf. Redinger 1938).

Other specimens examined: Republic of Korea, Gyeongsangbuk-do, Ulleung-gun, Ulleung-eup, Dodong-ri, Dodong Port, on rock. Lat.: $37^{\circ} 28^{\prime} 59.9^{\prime \prime}$ N; Long.: $130^{\circ} 54^{\prime} 40.7^{\prime \prime}$ E; Alt.: 20 m a.s.l. Coll.: Kondratyuk, S. Y., Lőkös, L. (162028), 11.07.2016 (KoLRI 040266 sub Enterographa, DNA voucher SK H37); the same locality growing together with Opegrapha ulleungdoensis and Verrucaria sp. (162050), (KoLRI 040288 sub Enterographa, DNA voucher SK H58). - Dokdo Islands, Eastern (Dokdo) Island, near stairs, on rocks growing together with Diploicia canescens. Lat.: $37^{\circ} 14^{\prime} 22.29^{\prime \prime}$ N; Long.: $131^{\circ} 52^{\prime} 10.55^{\prime \prime}$ E; Alt.: $17 \mathrm{~m}$ a.s.l. Coll.: Lee, B. G. (170900), 07.09 .2017 (KoLRI 045181 sub Diploicia canescens), the same locality, growing together with Diploicia canescens, (170901), (KoLRI 045182 sub Diploicia canescens, DNA voucher SK L26); the same locality, growing together with Buellia ulleungdoensis, and Diploicia canescens, (170902), (KoLRI 045183 sub Diploicia canescens); the same locality, growing together with Lecanora ussuriensis, and Diploicia canescens, (170903) (KoLRI 045184 sub Diploicia canescens). - Dokdo Islands, Eastern (Dokdo) Island, on rocks growing together with Opegrapha ulleungdoensis. Lat.: $37^{\circ} 14^{\prime} 21.61^{\prime \prime} \mathrm{N}$; Long.: $131^{\circ} 52^{\prime} 5.71^{\prime \prime} \mathrm{E}$; Alt.: 12 m a.s.l. Coll.: Oh, S.-O. (171071, 171072), 08.09.2017 (KoLRI 045352, KoLRI 045353 sub Opegrapha ulleungdoensis); the same locality, growing together with Diploicia canescens, (171077), (KoLRI 045358 sub Diploicia canescens), the same locality, growing together with Diploicia canescens, Opegrapha ulleungdoensis, and Orientophila dodongensis, (171078), (KoLRI 
045359 sub Diploicia canescens), the same locality, growing together with Opegrapha ulleungdoensis, (171079), (KoLRI 045360 sub Enterographa).

\section{Follmannia suborthoclada S. Y. Kondr. et J.-S. Hur, spec. nova}

(Fig. 6)

MycoBank No.: MB 836735

Similar to Follmannia orthoclada, but differs in having crustose areolate thallus, in having much darker reddish colour of thallus, in having biatorine-like apothecia, in having more or less subconvex disc in mature apothecia, in having narrower thalline margin, as well as in having longer and narrower ascospores and in having narrower ascospore septum.

Type: Chile: Cuesta Bvenos ayres, on rock, damaged by 'Lecidea' buellielloides. Lat.: $29^{\circ}$ 35' 11.7" S; Long.: 71 14' 52.9”' W; Alt.: 257 m a.s.l. Coll.: Oh, S.-O., Hur, J.-S. (CL130421), 13.11.2013 (KoLRI 020555 sub Follmannia suborthoclada - holotype, DNA voucher SK H91).

Thallus to 2-4(-5) cm across, but may form larger aggregation, dark reddish brown orange, crustose, areolate, mostly of scattered areoles (i.e. differs from Follmannia orthoclada in the lack or very rare overlapping long single thalline lobes); areoles mostly distant, scattered rarely aggregated, rounded $(0.15-) 0.3-0.5(-0.8) \mathrm{mm}$ across or irregularly elongated to $0.7-0.8 \mathrm{~mm}$ long and $0.4 \mathrm{~mm}$ wide; upper surface dull brownish orange; often areoles dispersed among other crustose lichens (with scattered areoles of Buellia/Lecidea spp.), sometimes with more or less whitish edge mostly with single apothecium or single conidiomata in the centre; subconvex or with undulating surface, edges are not closely attached to the surface; hypothallus absent.

Apothecia (0.2-)0.3-0.8(-1.0) mm diam., mostly 1 per areole; seem to be biatorine or sometimes as zeorine where thalline margin to $40-50 \mu \mathrm{m}$ wide seen at sides below own margin (Xanthocarpia crenulatella-type); own margin to $0.1 \mathrm{~mm}$ wide usually well seen (at 120×), slightly lighter than disc or concolorous with disc; mostly permanent, sometimes somewhat undulating or becoming thinner at overmature; disc mainly plane, dull reddish brownorange to dull brownish orange, darker than thallus (making aspect of thallus in macroscopical view); in section $0.4 \mathrm{~mm}$ thick, seem to be biatorine, while in section lecanorine or zeorine; thalline exciple 50-60 $\mu \mathrm{m}$ wide, algal cells to 12-15 $\mu \mathrm{m}$ diam.; true exciple 50-60(-90) $\mu \mathrm{m}$ wide in the uppermost lateral portion, paraplectenchymatous, cell lumina 5-10 $\mu \mathrm{m}$ across; $10-15 \mu \mathrm{m}$ thick in lower lateral and basal portion; hymenium 80-90 $\mu \mathrm{m}$ high; paraphysis tips to $4 \mu \mathrm{m}$ diam., slightly clavate; subhymenium $60-70(-100) \mu \mathrm{m}$ thick, hyaline, paraplectenchymatous, cell lumina to $5-10 \mu \mathrm{m}$ diam.; ascospores long and 

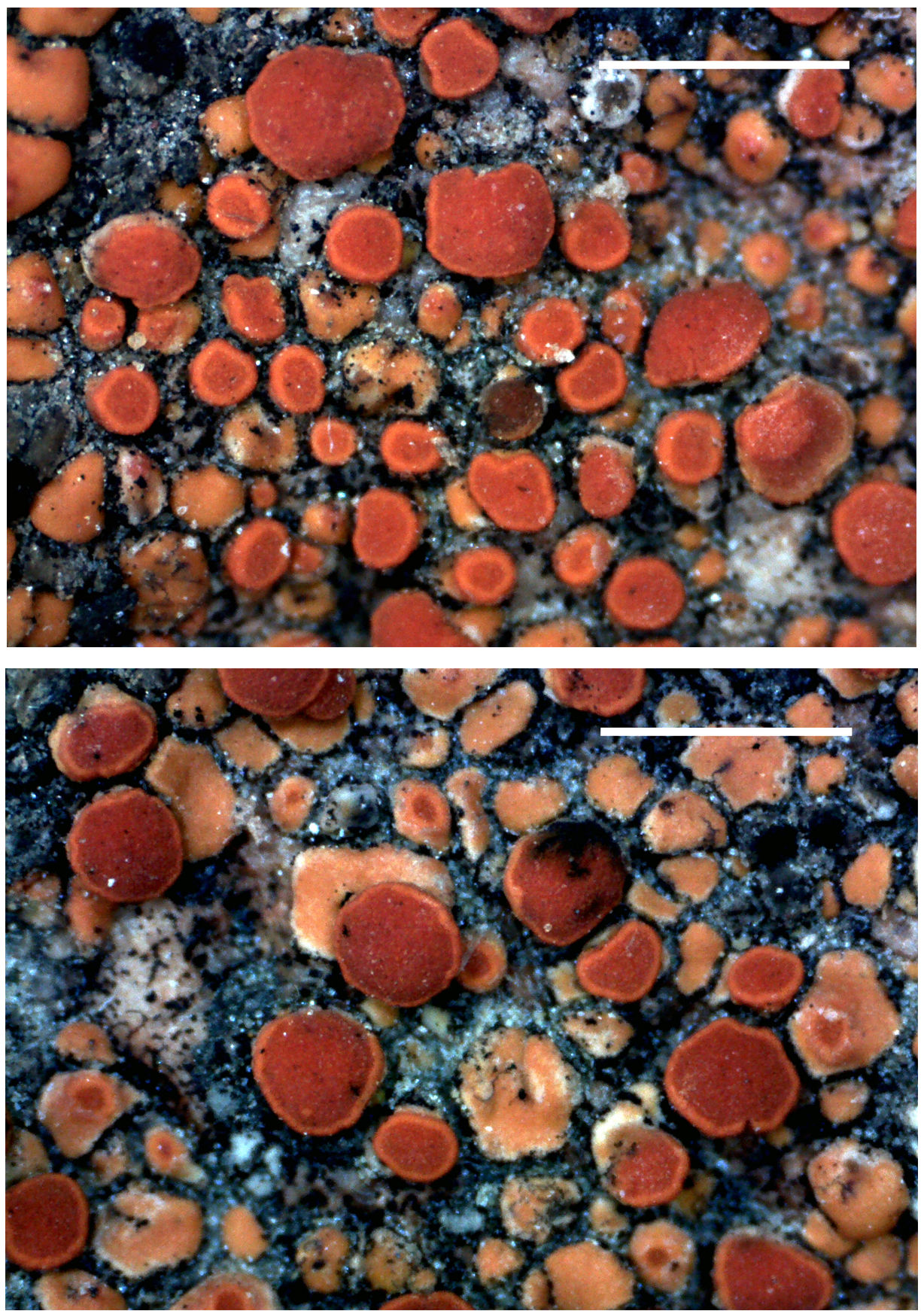

Fig. 6. Follmannia suborthoclada (CL130421, holotype), general habit. Scale $1 \mathrm{~mm}$ (photo: Kondratyuk, S. Y.) 
with narrow septum, $(12-) 13-15(-16) \times(4.0-) 4.5-5.2(-5.5) \mu \mathrm{m}$ in water and 12-15 × 5-5.5 $\mu \mathrm{m}$ in $\mathrm{K}$; septum narrow, 1.5-2 $\mu \mathrm{m}$ wide in water, 2-2.5 $\mu \mathrm{m}$ wide in K. Conidiomata mostly numerous 1-2 per areole, immersed, seen as reddish orange or darker reddish brown-orange spots; conidiomata to $230 \mu \mathrm{m}$ diam. and $170 \mu \mathrm{m}$ high, vertically elongated with hyaline walls; conidia bacilliform 3-4 × 0.7-0.8 $\mu \mathrm{m}$.

Chemistry: Epihymenium K+ purple or violet.

Etymology: It is named after similarity with Follmannia orthoclada.

Distribution and ecology: It is so far known from the type locality in Chile, South America. It grows on siliceous rocks together with some crustose lichens of Buellia/Lecidea, as well as with Follmannia orthoclada. The holotype CL130421 is damaged by 'Lecidea' buellielloides described below.

Taxonomic notes: Follmannia suborthoclada is similar to F. orthoclada (Zahlbr.) Frödén, Arup et Søchting* based on the size of ascospore and measurements of apothecia, but differs in having crustose areolate thallus (vs. placodioid, to $6 \mathrm{~cm}$ wide, in centre verruculoso-areolate, while lobes in peripheral zone to $1.5 \mathrm{~cm}$ long and $0.3-0.5 \mathrm{~mm}$ wide), in having much darker reddish colour of thallus (i.e. numerous apothecia form reddish-brownish colour of thallus, vs. yellowish), in having biatorine-like apothecia (vs. lecanorine while Gyalecta-type at the beginning), in having more or less subconvex disc in mature apothecia (vs. plane or concave), in having narrower thalline margin (vs. rather thick), as well as in having longer and narrower ascospores ((12-)13$15(-16) \times(4.0-) 4.5-5.2(-5.5) \mu \mathrm{m}$ vs. $8.5-10 \mu \mathrm{m} \times 5.0-5.2 \mu \mathrm{m})$ as well as in having narrower ascospore septum $(1.5-2 \mu \mathrm{m}$ wide vs. $2-3 \mu \mathrm{m}$ after our data while in original description 'isthmo tenui junctis'), in having narrower true exciple in uppermost lateral portion (50-60(-90) $\mu \mathrm{m}$ vs. to $150 \mu \mathrm{m}$ wide (our data)). Furthermore, F. orthoclada, growing side by side with F. suborthoclada differs also in having dull yellowish orange colour of thalline lobes, especially lighter yellowish lobe tips (Zahlbruckner 1924). Firstly, apothecia of this species are much larger than those mentioned in original description, i.e. to $1 \mathrm{~mm}$ diam., and to $0.45-0.55 \mathrm{~mm}$ thick in the section, while they were mentioned to $0.5 \mathrm{~mm}$ wide in original description ('parva usque $0.5 \mathrm{~mm}$ lata' Zahlbruckner (1924, p. 398)). Secondly, ascospore septum is much wider to $2-3 \mu \mathrm{m}$ wide in comparison with very narrow after original description 'isthmo tenui junctis'. It should also be especially emphasised that data on ascospores in Dodge's original description of Follmannia rufa are provided incorrectly, as subspherical $3 \mu \mathrm{m}$ diam. and asci polyspored. However, these data were corrected by Arup et al. (2013), who have revised the type specimen of F. rufa (i.e. it fits well of the description of $F$. orthoclada).

\footnotetext{
* We have to emphasise that there are two major corrections to the original description of F. orthoclada provided within our study.
} 
'Lecidea' buellielloides S. Y. Kondr. et J.-S. Hur, spec. nova (Figs 7-8)

MycoBank No.: MB 836736

Lichenicolous fungus similar to species of the genus Buelliella, but differing in having hyaline single ascospores.

Type: Chile: Cuesta Bvenos ayres, on rock, parasitic on thallus of Follmannia suborthoclada. Lat.: $29^{\circ} 35^{\prime} 11.7^{\prime \prime}$ S; Long.: 71 14' 52.9” W; Alt.: $257 \mathrm{~m}$ a.s.l. Coll.: Oh, S.-O., Hur, J.-S. (CL130421), 13.11.2013 (KoLRI 020555 sub Follmannia suborthoclada - holotype); the same locality, (CL130424), (KoLRI 020558 sub Follmannia suborthoclada - isotype); the same locality, (CL130425), (KoLRI 020559 sub Follmannia orthoclada - isotype, voucher for DNA SK H92).

Lichenicolous fungus forming ascomata on lichen-forming fungi Follmannia orthoclada and F. suborthoclada without any visible damage of host thallus.

Apothecial ascomata to (110-)180-200(-230) $\mu \mathrm{m}$ diam. and to (70-)110$160(-200) \mu \mathrm{m}$ high, black; exciple black to (30-)40-50(-60) $\mu \mathrm{m}$ thick above hymenium level, forming irregularly thickened portions to $30-40 \mu \mathrm{m}$ across, often with distinct cracks in the uppermost portion to 20-30 $\mu$ m wide/deep; 10-15 $\mu \mathrm{m}$ thick in lateral lower portion (at the hymenium level), and to 30-35 $\mu \mathrm{m}$ thick in basal portion; hymenium to $30-50(-60) \mu \mathrm{m}$ high, hyaline; subhymenium 20-25 $\mu \mathrm{m}$ thick, hyaline; ascospores single, hyaline, usually in one line in ascus, somewhat kidney-like, $(4.5-) 6-8(-10) \times 3-4(-4.5) \mu \mathrm{m}$. Conidiomata $0.6-0.7 \mathrm{~mm}$ diam., often associated with ascomata; wall blackish to 7-8 $\mu \mathrm{m}$ thick, paraplectenchymatous; conidia hyaline, bacilliform, straight or slightly curved, $5-9(-10) \times 0.7-0.8 \mu \mathrm{m}$.

Etymology: It is named after similarity to species of the genus Buelliella.

Distribution and ecology: So far it is known only from type locality, i.e. Chile, South America, where sometimes it was very abundant. It grows on lichen-forming fungi Follmannia orthoclada and F. suborthoclada without any visible damage of host thallus.

Taxonomic notes: 'Lecidea' buellielloides is similar to Buelliella inops registered in the same collections of Follmannia orthoclada. However, apothecia of Buelliella inops on Follmannia orthoclada (CL130381, KoLRI 020515, SK H95) in contrast to 'Lecidea' present in the cracks, somewhat between the thalline lobes, often similar to fungi of the genus Lichenothelia, and seem to be not lichenicolous fungus. Furthermore, apothecia of Buelliella are usually not immersed into the host thallus in contrast to 'Lecidea' buellielloides. 'Lecidea' buellielloides differs also from Buelliella inops in having smaller, hyaline and simple ascospores (Santesson 1994). Thelidiola caloplacae (C. W. Dodge et G. E. Baker) C. W. Dodge and Thelidium caloplacae C. W. Dodge et G. E. Baker were mentioned on Follmannia rufa, but later they were included in the synonyms of Muellerella lichenicola (Lamb 1963). 

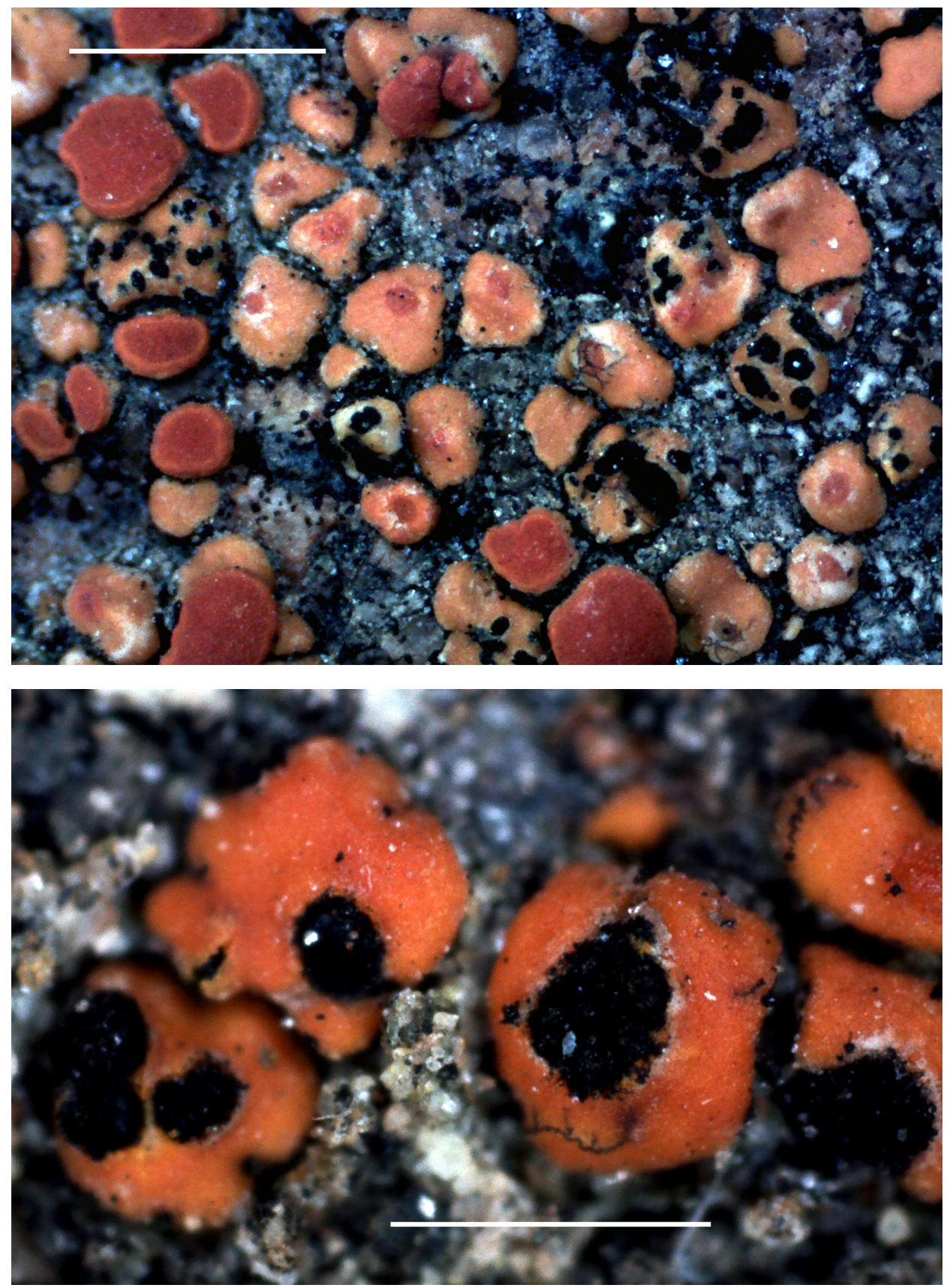

Fig. 7. 'Lecidea' buellielloides (CL130421, holotype), general habit. Scale $1 \mathrm{~mm}$ (top), $0.5 \mathrm{~mm}$ (bottom) (photo: Kondratyuk, S. Y.) 

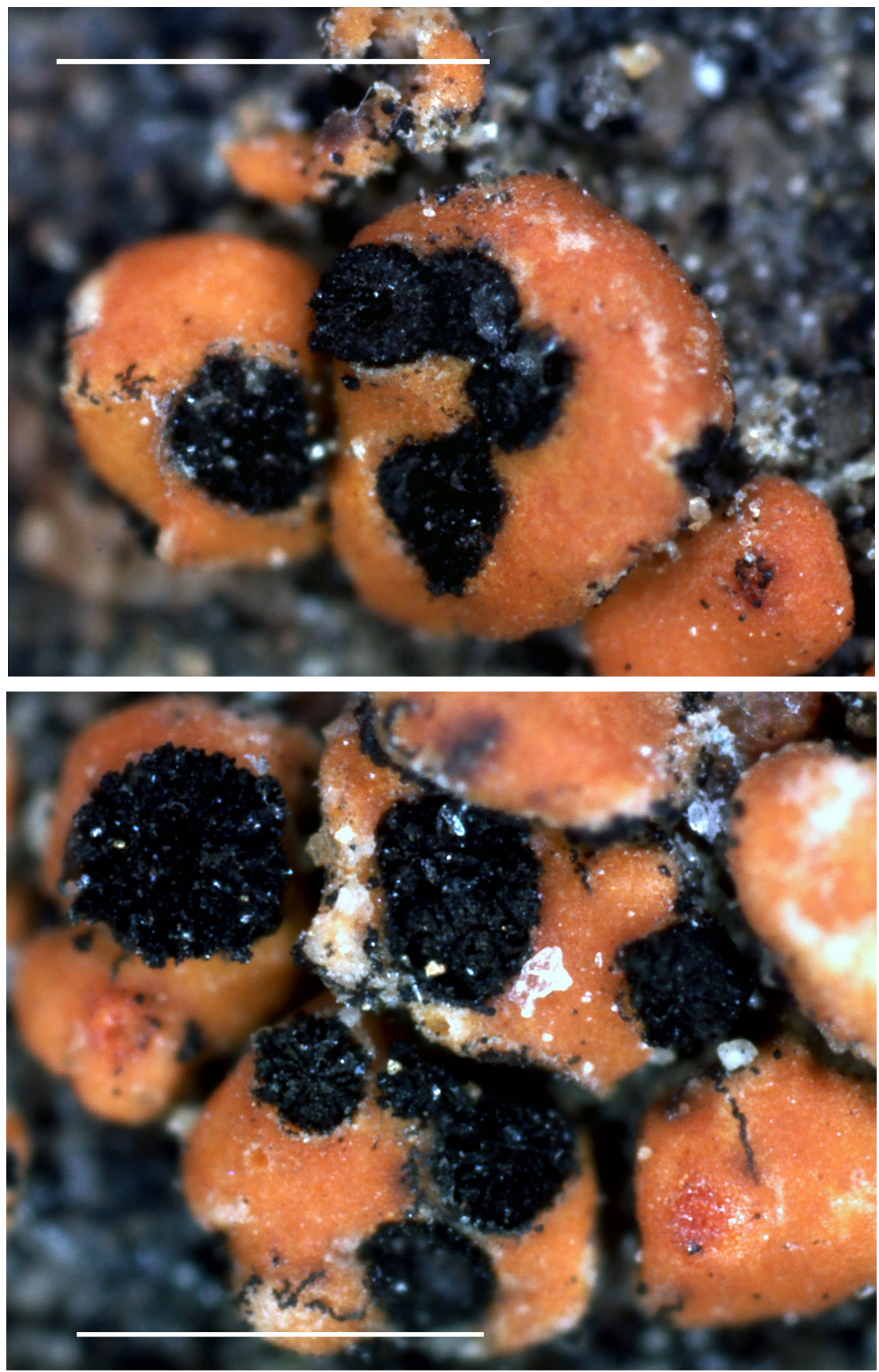

Fig. 8. 'Lecidea' buellielloides (CL130421, holotype), enlarged host thalline areoles with ascomata. Scale $0.5 \mathrm{~mm}$ (photo: Kondratyuk, S. Y.) 
Massjukiella rusavskioides S. Y. Kondr. et J.-S. Hur, spec. nova (Figs 9-11)

MycoBank No.: MB 836737

Similar to Calogaya mogoltanica, but differs in having smaller thallus, in having shorter and narrower thalline lobes, and in having soredia and consoredia, as well as in the lack of regular rosette-like thalli, in the lack of papillae and verrucae in the centre of thallus.

Type: Chile: Patagonia, Torres del Paine, Y200 30 km, on rock. Lat.: 51 19' 12.1" S; Long.: 72 40' 18.7" W; Alt.: ca 64 m a.s.l. Coll.: Oh, S.-O., Hur, J.-S. (CL130219), 19.01.2013 (KoLRI 017652 - holotype, DNA voucher SK B24, SK A28, SK A29, SK A30).

Thallus 1-3 cm across, distinctly lobate in the peripheral zone, and extremely thick, somewhat 'pseudoareolate', and richly soredious in the centre, deep yellow to yellow orange. Lobes seen only in very narrow peripheral zone up to $0.5-2 \mathrm{~mm}$ wide, seen as lobes to $1.5-2 \mathrm{~mm}$ long, and very narrow, to $0.4-$ $0.6 \mathrm{~mm}$ wide throughout, or if distinctly widened towards the tips, to $0.9-1.5$ mm wide, very convex, with undulating upper surface and hollow medulla, forming entire mass, without distinct lobe edges in the centre; central part of very thick, to $1-1.5 \mathrm{~mm}$ thick, densely pressed lobes, sometimes forming discrete 'pseudoareoles' to 1.5-2(-3.5) mm across where only upper portion of lobes forming 'pseudoareoles', but lower part of thallus is continuous, richly sorediate, while soredia not well distinct. Soredia (25-)35-55(-75) $\mu \mathrm{m}$ diam., but soon becoming aggregated into consoredia 70-80(-100) $\mu \mathrm{m}$ diam./across and becoming isidious, conglutinated and not forming lax soredious mass. Single soredia almost the same size as consoredia (to $75 \mu \mathrm{m}$ diam./across) are often observed, rounded aggregations of consoredias to $0.1-0.15 \mathrm{~mm}$ across are sometimes present, too. Upper surface of lobes very uneven, undulating and somewhat verrucose. In section thallus to 100-150 $\mu \mathrm{m}$ thick. Cortical layer very varying in thickness, $c a 10-15 \mu \mathrm{m}$ above algal clusters and to 30 $\mu \mathrm{m}$ thick between algal clusters, leptodermatous paraplectenchymatous, cells vertically elongated, cell lumina 5-7 $\mu \mathrm{m}$ across (or 5-8 $\times 2.5-4 \mu \mathrm{m}$ ), algal zone 50-90 $\mu \mathrm{m}$ thick, medulla hollow.

Apothecia and conidiomata not known.

Chemistry: Thallus and soredious mass K+ purple, containing parietin.

Etymology: It is named after similarity with species of the genus Rusavskia, the subfamily Xanthorioideae, Teloschistaceae.

Distribution and ecology: So far known from type collection from South America, Chile. It grows on siliceous rock. 

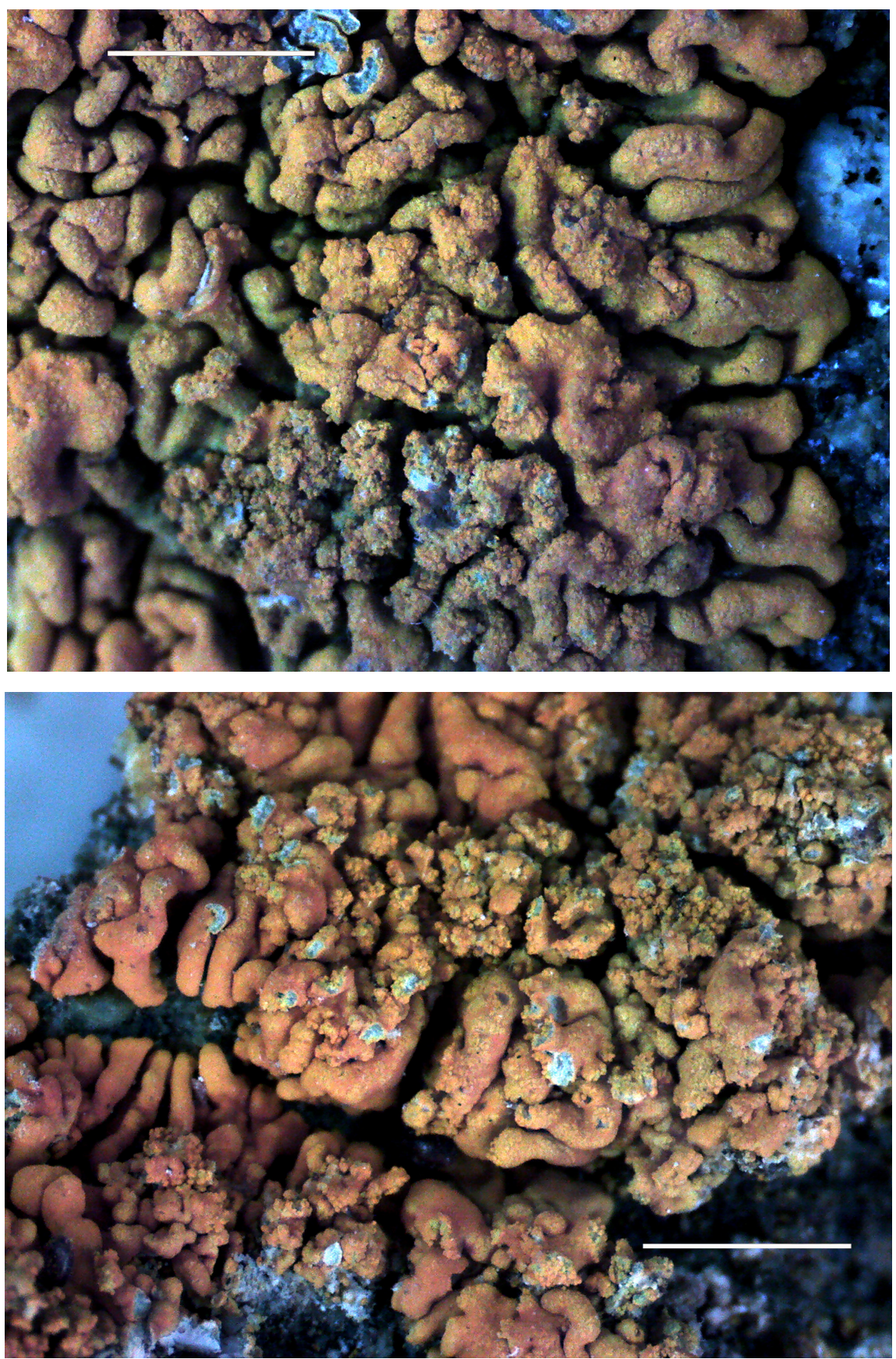

Fig. 9. Massjukiella rusavskioides (holotype), general habit. Scale 2 mm (photo: Kondratyuk, S. Y.) 

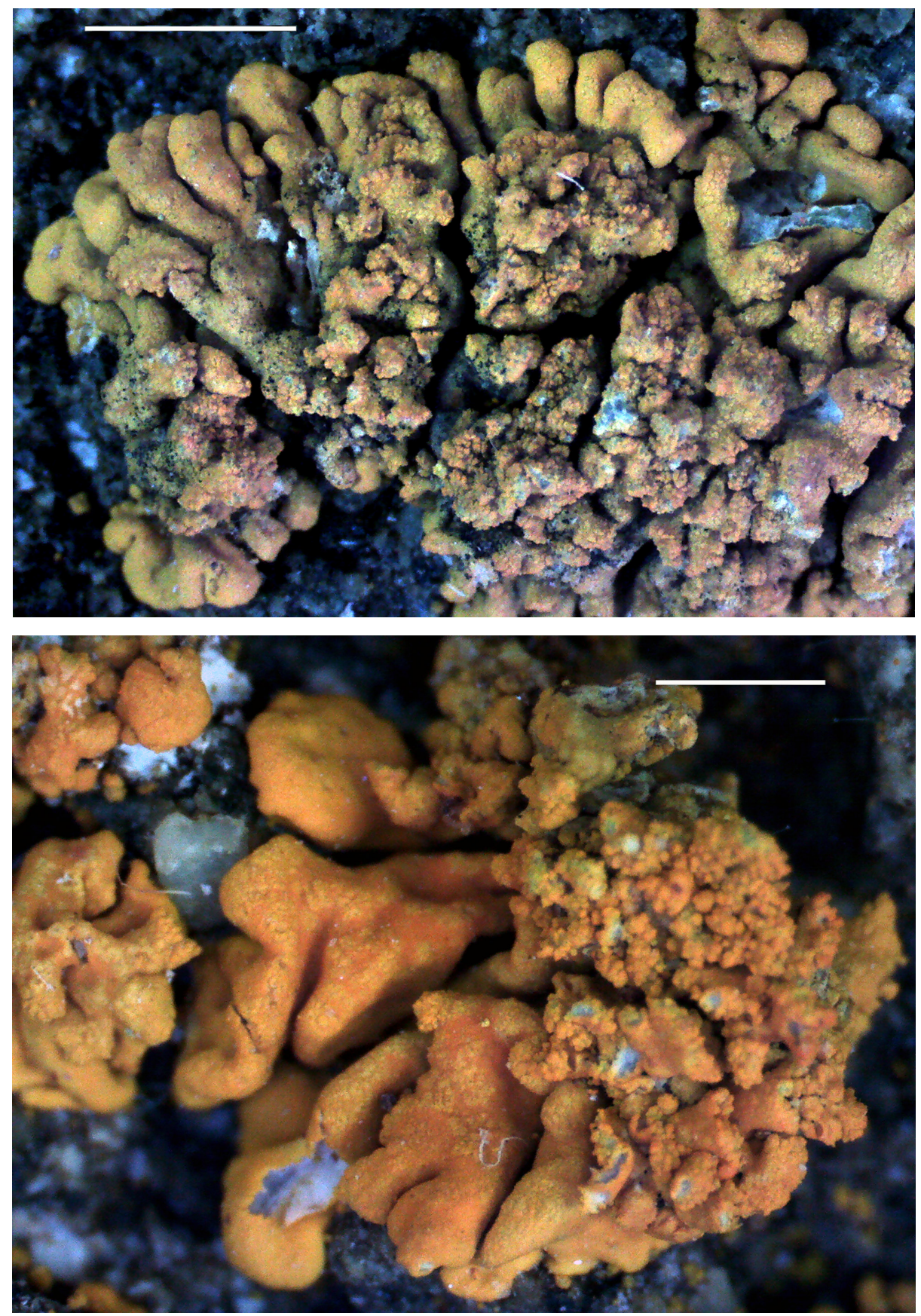

Fig. 10. Massjukiella rusavskioides (holotype), general habit (top) and enlarged marginal portion (bottom). Scale $2 \mathrm{~mm}$ (top) and $1 \mathrm{~mm}$ (bottom) (photo: Kondratyuk, S. Y.) 

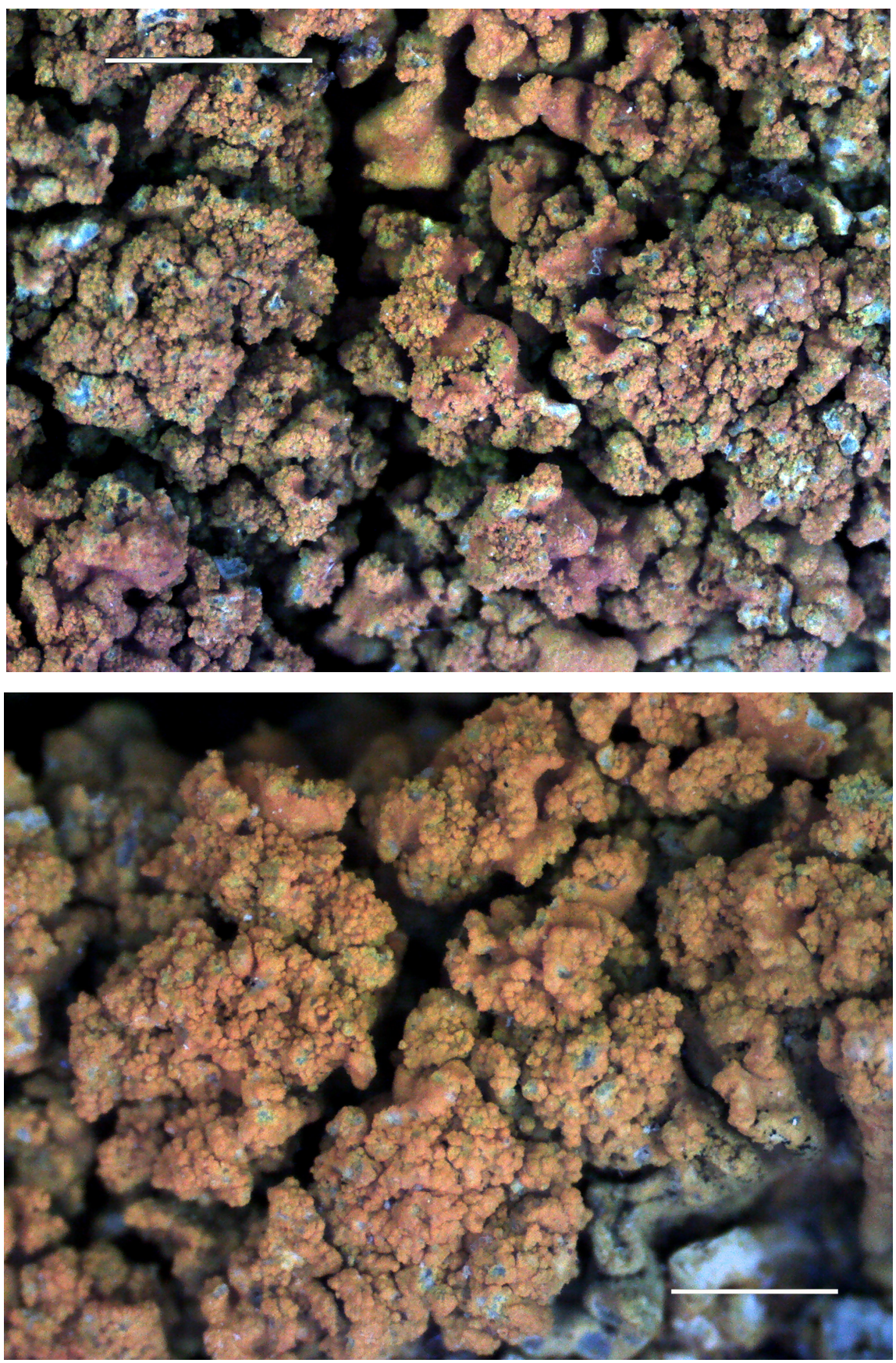

Fig. 11. Massjukiella rusavskioides (holotype), enlarged central sorediate portion of thallus. Scale $2 \mathrm{~mm}$ (top) and $1 \mathrm{~mm}$ (bottom) (photo: Kondratyuk, S. Y.) 
Taxonomic notes: Massjukiella rusavskioides is similar to the Middle Asian species Calogaya mogoltanica (S. Y. Kondr. et Kudratov) S. Y. Kondr. et al. in having very thick thalline lobes with undulating upper surface forming entire mass without distinct lobe edges, but differs in having smaller thallus $(1-3 \mathrm{~cm}$ vs. $2.5-4 \mathrm{~cm}$ across), in having shorter (1.5-2 $\mathrm{mm}$ vs. $5-7 \mathrm{~mm}$ long) and narrower (0.4-0.6 mm vs. 1-2 $\mathrm{mm}$ wide) thalline lobes, and in having soredia and consoredia, as well as in the lack of regular rosette-like thalli, in the lack of papillae and verrucae in the centre of thallus (Kondratyuk and Kudratov 2003, Kondratyuk et al. 2004). Massjukiella rusavskioides is similar to Calogaya decipiens (Ach.) Arup, Frödén et Søchting, a widely distributed species in the Northern Hemisphere, but differs in having shorter lobes (1.5-2 mm vs. 2-3 $(-5) \mathrm{mm}$ long), in having much thicker thallus, as well as in having very highly arising thalline lobes, which are narrower in the centre and much wider towards the tips, as well as in the lack of differentiation on main lobes and secondary lobules, in the lack of well-developed lip-like or head-like soralia on the tips of the secondary lobules and in the lack of yellowish or whitish pruina on thallus (Kondratyuk et al. 2004). After having especially soredious central part of thallus Massjukiella rusavskioides is similar to Xanthomendoza mendozae (Räsänen) S. Y. Kondr. et Kärnefelt, a widely distributed species in South and North America, but differs in having well-developed lobate peripheral zone of thallus, in having different thallus anatomy (vs. paraplectenchymatous upper cortical layer, thick medullary plectenchyma and prosoplectenchymatous lower cortex), in having much smaller soredia, as well as in the lack of rhizines (Kondratyuk and Kärnefelt 1997). Massjukiella rusavskioides is similar to the European Rusavskia hafellneri S. Y. Kondr. et Kärnefelt, another sorediate species for which so far fertile collections are unknown (Kondratyuk and Kärnefelt 2003). Unfortunately, molecular data on $R$. hafellneri are hitherto missing, so this hypothesis can be checked later. Since voucher specimens SK A28, SK A29, SK A30 and SK B24 of Massjukiella rusavskioides are positioned in the same branch with Polycauliona stellata (Wetmore et Kärnefelt) Arup, Frödén et Søchting, P. tenax (L. Lindblom) Frödén, Arup et Søchting, and P. tenuiloba (L. Lindblom) Frödén, Arup et Søchting (KC179568), as well as Polycauliona impolita and P. pollinarioides as after separated by the nrITS, the nrLSU phylogeny, and $12 \mathrm{~S}$ mSSU phylogeny as the combined phylogeny of the Xanthorioideae based on three gene sequences, five new combinations for the genus Massjukiella for species mentioned above are proposed below. It should be emphasised that our own data on the former Xanthoria tenax (see Kondratyuk et al. 2013a), and data of Arup et al. (2013) as a member of the Wetmoreana clade and as a member of the Polycauliona s. lat. are very contradictory. So, we have to draw conclusion that material of 'Xanthoria' tenax is probably heterogeneous, including two or more taxa, and real position of 
'Xanthoria' tenax is to be revised on the basis of analysis of type specimen or freshly collected specimen from the type locality. Probably the combination of 'Xanthoria' tenax to Wetmoreana is based on another, maybe still undescribed species and it should be repeatedly revised.

Neobrownliella salyangensis S. Y. Kondr. et J.-S. Hur, spec. nova (Fig. 12)

MycoBank No.: MB 836738

Similar to Neobrownliella montisfracti, but differs in having well-developed yellow thallus and dull orange-yellow apothecia, in having smaller areoles, in having wider paraphyses tips, in having wider ascospore septum.

Type: Republic of Korea: Gyeongnam Prov., Tongyeong City, Salyang Island. Lat.: $34^{\circ} 50.555^{\prime}$ N; Long.: $128^{\circ} 12.179^{\prime}$ E; Alt.: ca 25 m a.s.l. Coll.: Wang, X. Y., Joshi, Y., Han, J. H. (110011), 20.04.2011 (KoLRI 012954 sub Lecidella enteroleucella - holotype).

Thallus (1-)3-5 mm diam./across, very small, crustose, areolate; areoles dull yellow, very thin, almost immersed into substrate at first, then to 0.3-0.5 $\mathrm{mm}$ diam./across, in the centre completely covered by apothecia.

Apothecia $0.2-0.45 \mathrm{~mm}$ diam., in section to $0.15 \mathrm{~mm}$ thick, very small, immersed into thalline areoles, from cryptolecanorine to zeorine, from 1 to $4(-5)$ per areole; from regularly rounded to somewhat irregular; disc dull orange-yellow, sometimes own margin/true exciple to $40 \mu \mathrm{m}$ wide, more yellowish than disc, but sometimes darker than yellow thallus observed. In section true exciple to $60(-70) \mu \mathrm{m}$ thick in the uppermost and to 20-30 $\mu \mathrm{m}$ thick in lower portion, paraplectenchymatous, cell lumina to $4-7(-10) \mu \mathrm{m}$ across, to $10 \mu \mathrm{m}$ thick or indistinct in basal; hymenium 60-70 $\mu \mathrm{m}$ high; paraphyses do not reach the uppermost portion of hymenium (rather thick gelatinous layer above paraphyses tips observed, better seen in K), distinctly swollen towards the tips to $4 \mu \mathrm{m}$ diam.; subhymenium to 30-35 $\mu \mathrm{m}$ thick, hyaline, without oil droplets; asci 8-spored, often with ascospores variegated in size within the same ascus; ascospores narrowly fusiform or rather widely ellipsoid, with more or less attenuated ends or with rounded ends, $8-12 \times(5-) 5.5-6(-7) \mu \mathrm{m}$ in water $(\mathrm{n}=20)$ and $(6-) 7-12(-13) \times(4.5-) 5-7 \mu \mathrm{m}$ in $\mathrm{K}(\mathrm{n}=33)$; ascospore septum to $3-4 \mu \mathrm{m}$ thick in water and (2-)2.5-5.5(-6) $\mu \mathrm{m}$ wide in $\mathrm{K}$.

Chemistry: Thallus and apothecia $\mathrm{K}+$ purple.

Etymology: It is named after the type locality, i.e. Salyang Island, South Korea, Eastern Asia. 

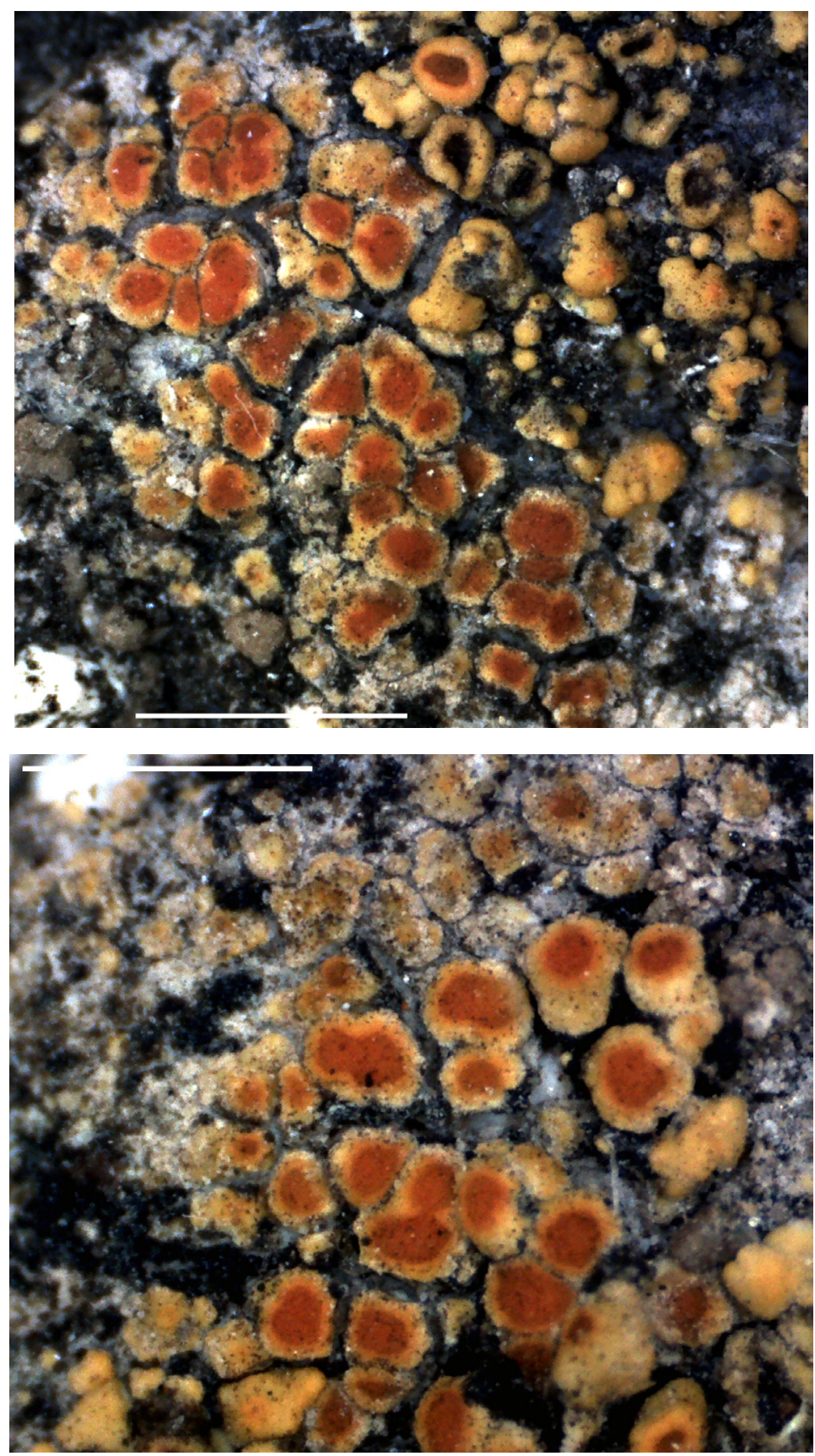

Fig. 12. Neobrownliella salyangensis (110011, holotype) growing side by side with Huriella salyangiana (top). Scale $1 \mathrm{~mm}$ (photo: Kondratyuk, S. Y.) 
Distribution and ecology: It is so far known from two islands of South Korean archipelago, Eastern Asia. It grows on siliceous rock, associated with Lecidella enteroleucella.

Taxonomic notes: Neobrownliella salyangensis is similar to the Australian inland lichen N. montisfracti (S. Y. Kondr., Elix et Kärnefelt) S. Y. Kondr., Elix, Kärnefelt et A. Thell, but differs in having well-developed yellow thallus (vs. dull pink to grey with rose tinge or indistinct) and dull orange-yellow apothecia (vs. bright red or pink red), in having smaller areoles $(0.3-0.5 \mathrm{~mm}$ vs. $0.3-0.7 \mathrm{~mm}$ or $0.4-1.0 \mathrm{~mm}$ across in peripheral zone), in having wider paraphyses tips (to $4 \mu \mathrm{m}$ vs. $2-3 \mu \mathrm{m}$ wide), in having wider ascospore septum (3-4 $\mu \mathrm{m}$ vs. $2.5-3.5 \mu \mathrm{m}$ wide), while ascospores are almost the same $(8-12 \times$

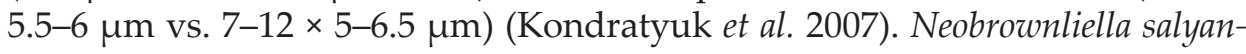
gensis (as well as N. montisfracti) is similar to three other pink, epilithic inland species Filsoniana australiana (S. Y. Kondr., Kärnefelt et Filson) S. Y. Kondr., Kärnefelt, Elix, A. Thell et Hur, Caloplaca aliciae S. Y. Kondr., Kärnefelt et Elix, and Caloplaca astonii S. Y. Kondr. et Kärnefelt*, but distinctly differs from latter species by its distinctly crustose thallus, which becomes very thin towards the margins and by the immersed dull orange-yellow apothecia, as well as by lack of well-developed hypothallus. Morphologically some specimens of Neobrownliella salyangensis are very similar to the Australasian Filsoniana scarlatina (Zahlbr.) S. Y. Kondr., Kärnefelt, Elix, A. Thell et J.-S. Hur and anatomical studies may be required to distinguish them. However, apothecia F. scarlatina are never immersed like they are in Neobrownliella salyangensis. Furthermore, $N$. salyangensis can be distinguished by having very closely appressed, plane to rather large, convex areoles, as well as by the reddish brown to orange brown coloured thalli, as well as by its distribution (Kondratyuk et al. 2012). It should be emphasised that after ITS phylogeny there is one more specimen of Neobrownliella salyangensis from Dokdo Island, South Korea (voucher SK L16, i.e. 170891 KoLRI) confirmed by recent collection in 2017. However, this collection is pending better herbarium specimens and data on other genes, too.

Other specimen examined: Republic of Korea, Jeju-do, Seogwipo-si, Seongsan-eup, Goseong-ri, Seopjicoji, on rock, growing together with Huriella pohangensis and Endocarpon sp. Lat.: $33^{\circ} 19^{\prime} 21.0^{\prime \prime}$ N; Long.: $126^{\circ} 50^{\prime} 49.03^{\prime \prime}$ E; Alt.: $69 \mathrm{~m}$ a.s.l. Coll.: Joshi, Y., So, J. E. (140477), 19.06.2014 (KoLRI 022878 sub Huriella).

\footnotetext{
* Possibly the latter species, i.e. C. aliciae and C. astonii, are also members of the genus Neobrownliella, but this hypothesis is waiting for confirmation by molecular data.
} 


\section{Pyrenodesmia vernadskiensis S. Y. Kondr., T. O. Kondratiuk et I. Yu. Parnikoza, spec. nova} (Figs 13-18)

MycoBank No.: MB 836739

Similar to Huea grisea, but differs in having exclusively microfruticose thallus consisting of very narrow, richly branched thalline filaments and forming dense and compact tufts, or richly fertile portions only with hypothallus developed, as well as in the lack of crustose thallus and in the lack of well-developed cortical, algal and medullary layers of thallus.

Type: Western coast of Antarctic Peninsula. Argentine Islands, Winter Island, base of old flagstick, S $64^{\circ} 15^{\prime} 16.9^{\prime \prime}, \mathrm{W} 65^{\circ} 15^{\prime} 4.2^{\prime \prime}$ [ = S 65.25116, $\mathrm{W} 64.25469^{\circ}$ ], on siliceous rock surface, overgrowing mosses and rock surface and bryophyte remnants, growing together with Lecanora polytropa aggr., as well as Lepraria spp. Parnikoza, I. Y. (IP7), 02.03.2020 (KW-L sub Pyrenodesmia vernadskiensis - holotype); the same locality, on bryophyte remnants, growing together with Lepraria, Lecanora, and Polyblastia spp. Parnikoza, I. Y. (IP1), 02.03.2020 (BP sub Pyrenodesmia vernadskiensis - isotype); the same locality, on bryophyte remnants, growing together with Lecanora polytropa, damaged by Cercidospora sp. Parnikoza, I. Y. (IP2), 02.03.2020 (LD sub Pyrenodesmia vernadskiensis - isotype).

Thallus microfruticose or rarely crustose where mostly hypothallus well developed at initial stage and very thin scattered and distant areoles soon forming cylindrical elongated isidia-like outgrowths; rather small, (1.7-)2-3 $(-5)[-13] \mathrm{cm}$ across/diam., can be aggregated in larger groups (to 13 or more $\mathrm{cm}$ across), forming from $0.5 \mathrm{~mm}$ to $1.5-2(-3) \mathrm{mm}$ thick, semiconvex or rather convex hemispherical cushions, very dark grey or brown grey in exposed conditions, while whitish grey or light grey to greenish grey in shaded portions; thalline filaments very delicate, very crumble, consisting of very thin ca (30-)50-80 $\mu \mathrm{m}$ diam., mostly vertical, ascending, terete, richly or moderately branched isidia-like lobules, whitish grey to dark brown grey, especially tips of lobules darker coloured (dark brown to dark brown grey), while in the lower portion much lighter, i.e. light grey or whitish grey to dirty white; thalline lobes/filaments cylindrical to $0.5-1.5(-2) \mathrm{mm} \mathrm{long}^{*}$ and to (40-)50-80 $\mu \mathrm{m}$ diam. in section, thickness of lobe/filaments weakly variegated to almost the same throughout; secondary lobes the same wide; total width of single thalline fragment with all secondary lobules to $1.0-1.5 \mathrm{~mm}$ wide, but mostly densely aggregated and forming dense cushions, especially in their outermost

\footnotetext{
* Length of filaments/lobes sometimes hardly distinct as they form very dense aggregations within the upper part of thallus, ca 50-90(-120) $\mu \mathrm{m}$ thick, where they are packed very densely, filaments poorly branched and mainly parallelly elongated. However, tree-like richly ramified filaments/lobes to $1.5-2 \mathrm{~mm}$ long solutely attached to the substrate are observed, too (Fig. 15a, b).
} 



Fig. 13. Holotype (Wordie House) locality of Pyrenodesmia vernadskiensis (top) and paratype (Galindez Island) locality of Pyrenodesmia vernadskiensis (bottom) (photo: Parnikoza, I. Yu., 02.03.2020) 

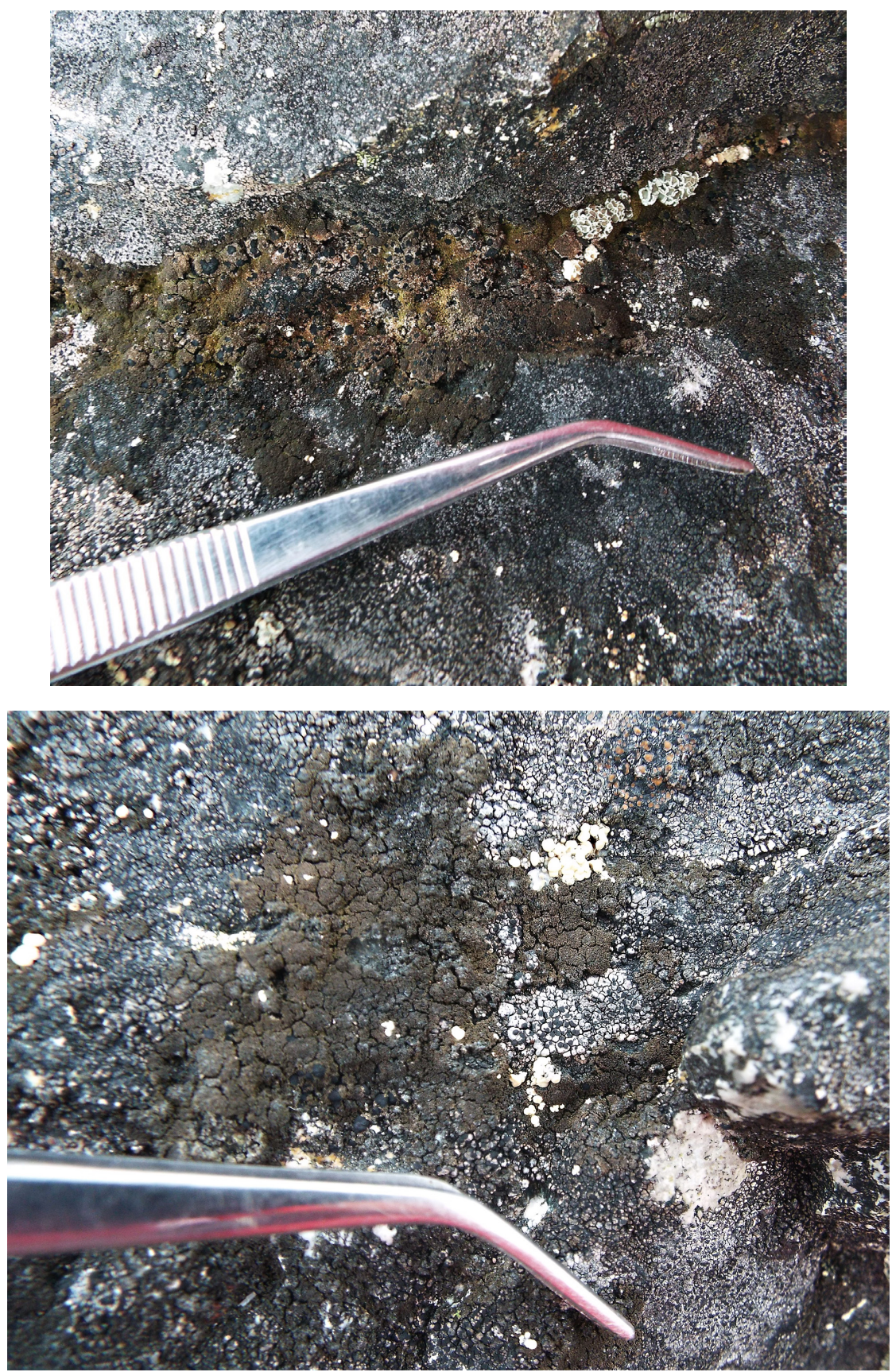

Fig. 14. Pyrenodesmia vernadskiensis (holotype). General habit of fragment growing with Lecanora (top) and general habit of fragment growing with Lecidea (bottom) (photo: Parnikoza, I. Yu., in field, 02.03.2020) 
portions, rarely in lax aggregations; algal cells/aggregations better presented in the uppermost portions, while in lower portion they seem to be very irregular. Hypothallus is well developed at initial stage, sometimes with numerous apothecia, while not observed when microfruticose thalline tufts are formed.

Apothecia to $0.5-0.8 \mathrm{~mm}$ diam., $0.3 \mathrm{~mm}$ thick in section; lecideine, mostly with distinct own margin, black and concolorous with disc, ca 50-60 $\mu \mathrm{m}$ wide, somewhat waved, distinctly uplifted above disc level, disc more or less even or somewhat subconvex, matt black; lecideine or biatorine in section, true exciple becoming very thin, to 20-30 $\mu \mathrm{m}$ thick in the uppermost lateral portions, and to $50-70(-100) \mu \mathrm{m}$ thick in basal portion, brownish black; hymenium to (50-)55-65 $\mu \mathrm{m}$ high, rather low, uppermost portion bluish or bluish green, while lower portion hyaline; subhymenium 50-150(-170) $\mu \mathrm{m}$ thick, somewhat yellowish to brownish yellow, sometimes as 50-70 $\mu \mathrm{m}$ thick, while dark brown or blackish stipe to $100 \mu \mathrm{m}$ thick observed; epihymenium to $6 \mu \mathrm{m}$ thick, dull brownish-bluish to blackish in the uppermost portion, sometimes with fragments of gel; paraphyses with the uppermost portion to $18 \mu \mathrm{m}$ long dark brown, while lower portion hyaline/transparent; uppermost cells to $4-5(-7)$ $\mu \mathrm{m}$ diam. (in water and to $4-5 \mu \mathrm{m}$ diam. in $\mathrm{K}$ ), somewhat with cups; asci 50-60 × 12.5-15 $\mu \mathrm{m}$, often with (1-)2-4 bipolar and not developed (abortive single) ascospores together; ascospores bipolar very rarely seen per section of apothecium while young/undeveloped abortive simple ascospores are very common; bipolar ascospores widely ellipsoid, ends more or less rounded, sometimes almost to spherical, 11-14 × (6.5-)7.5-9.5 $\mu \mathrm{m}$ in water and (10-) $11-15(-16) \times 7.5-9(-11) \mu \mathrm{m}$ in $\mathrm{K}$ and with much thicker to $1.0-1.5 \mu \mathrm{m}$ thick ascospore wall in $\mathrm{K}$; ascospore septum (3.5-)4-6(-6.5) $\mu \mathrm{m}$ wide in water and 4-7.5(-8) $\mu \mathrm{m}$ wide in $\mathrm{K}$.

Chemistry: All elements of apothecium $\mathrm{K}-$ or internal portion of true exciple becoming slightly reddish brown; epihymenium $\mathrm{K}+$ becoming more intense blue greenish or bluish green.

Etymology: It is named after the type locality, i.e. V. I. Vernadsky Ukrainian Antarctic Station, which is situated on Galindez Island of Argentine Islands, the Maritime Antarctic.

Distribution and ecology: It is so far known from several distant localities, i.e. Winter and Galindez Islands of Argentine Islands, the Maritime Antarctic, Southern Hemisphere. It grows on rock surface or on remnants of bryophytes or dusty places especially along rock cracks, rarely directly on bare rock surface; often on vertical or somewhat inclined surfaces together with bryophytes and Usnea antarctica, as well as species of the genera Lecanora, Lepraria, Ochrolechia, Candelariella, Usnea, Umbilicaria and often overgrowing thalli of members of the genera Lecanora, Lepraria and Protoparmelia. 

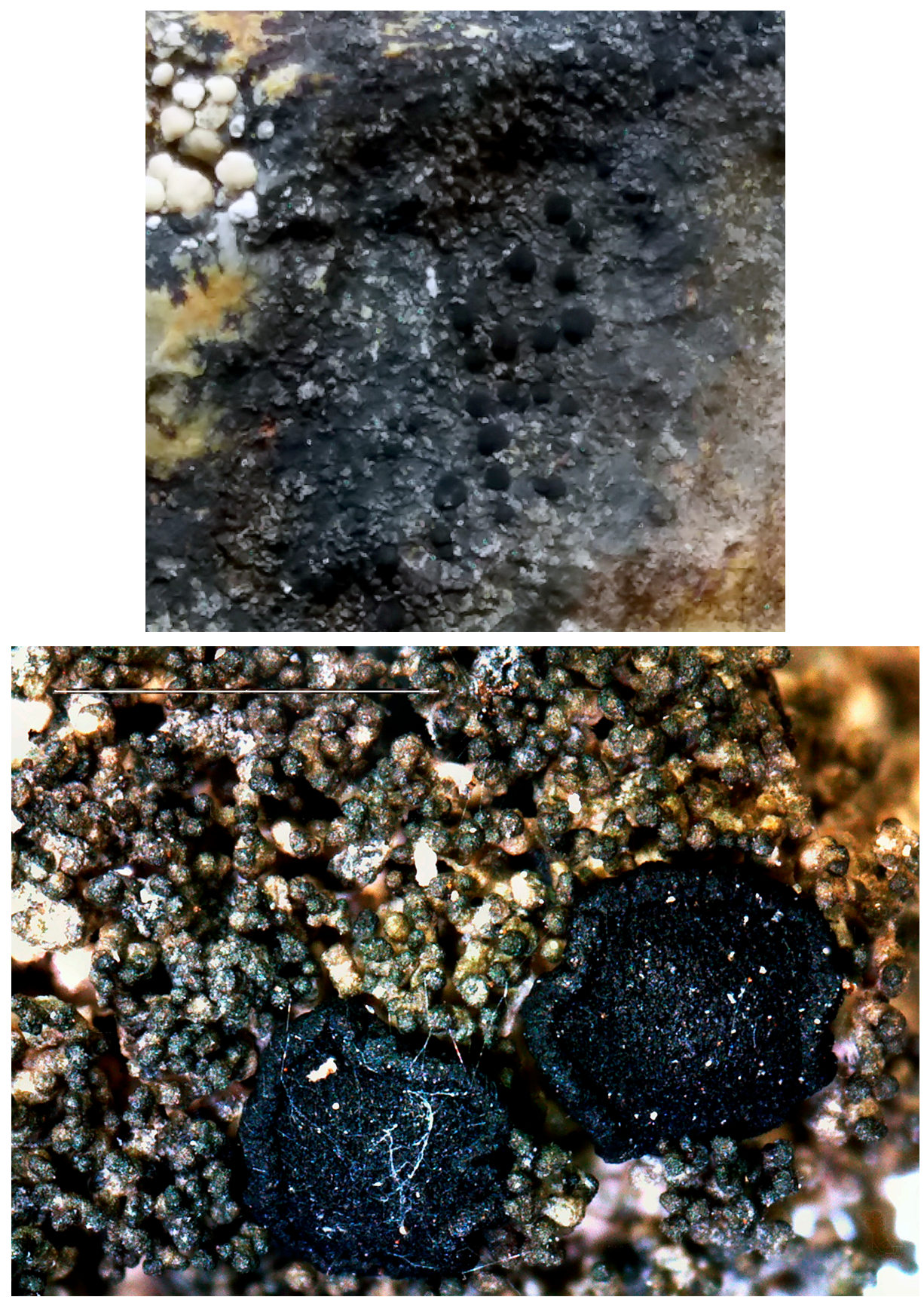

Fig. 15. Pyrenodesmia vernadskiensis (holotype). General habit of fragment growing on rock (top) and enlarged portion of thallus with lecideine apothecia. Scale $1 \mathrm{~mm}$ (bottom) (photo: Kondratyuk, S. Y.) 

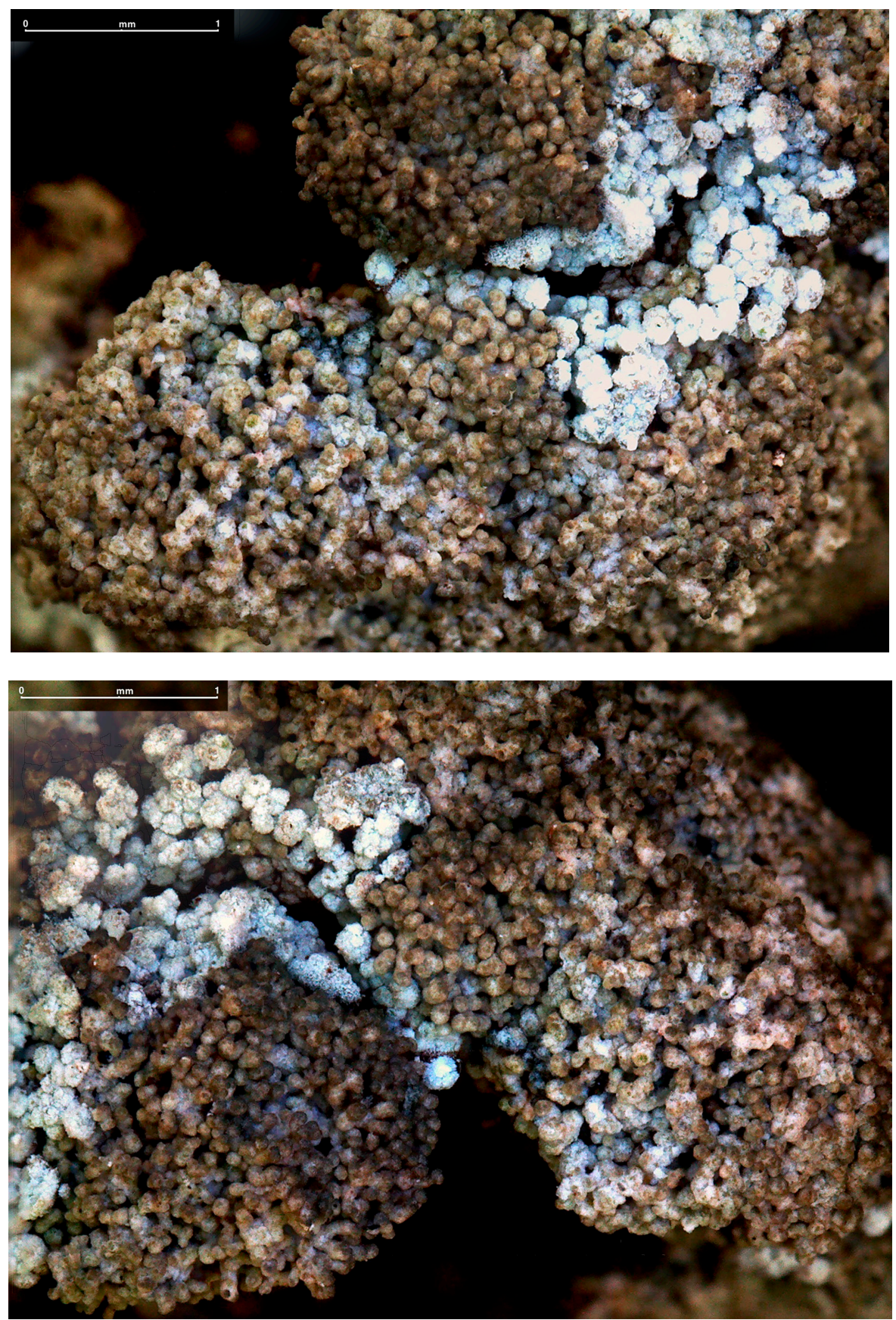

Fig. 16. Pyrenodesmia vernadskiensis (holotype), enlarged thallus without apothecia, growing together with Lepraria sp. Scale $1 \mathrm{~mm}$ (photo: Kondratyuk, S. Y.) 
Taxonomic notes: Pyrenodesmia vernadskiensis is a rather indistinct crustose lichen, which is mostly presented on very small fragments on rock surface, on bryophyte remnants and sometimes hardly seen among other crustose lichens of the genera Lecanora, Lepraria, Lecidea, Rhizocarpon, etc. This lichen is rather small and it is difficult to recognise in field conditions, often similar to species of the genera Coppinsidea and Polyblastia overgrowing bryophyte tufts. In holotype locality it is found to be rather abundant. Richly fertile specimens were especially investigated in field as well as in laboratory conditions in 2020 on matter of variation of thallus. It is found that the range of thallus variation is rather wide from well-developed black hypothallus and only very thin initial scattered areoles, which soon produce finger-like, elongated, irregularly orientated outgrowths, while these specimens are richly fertile, on bare rock surface to very thick microfruticose tufts to $1-2 \mathrm{~cm}$ thick above dust or bryophyte remnants or among other lichen thalli mostly along cracks on vertical or inclined surface of siliceous rocks. However, it should be mentioned that the stage with well-developed corticate thallus, which is diagnostic for Huea grisea, is still missing for Pyrenodesmia vernadskiensis. P. vernadskiensis is similar to Huea grisea (Vainio) I. M. Lamb (syn. H. coralligera (Hue) C. W. Dodge et G. E. Baker), but differs in having exclusively microfruticose thallus consisting of very narrow, $40-70 \mu \mathrm{m}$ diam., richly branched thalline lobes and forming dense and compact tufts by the uppermost portions of thalline lobes, or in having well-developed black hypothallus with numerous apothecia, as well as in the lack of crustose thallus and in the lack of well-developed cortical, algal and medullary layers of thallus. Unfortunately, measurements on isidia of Huea coralligera are still missing in original descriptions of Hue and Vainio. It should be mentioned that maybe Pyrenodesmia vernadskiensis was previously in parts recorded from Galindez Island by Dodge (1973) as a rather common species on this island under the name of Huea coralligera. All Antarctic specimens previously identified as Pertusaria grisea, Huea grisea and $H$. coralligera are in urgent need of revision if there are probably some more specimens of the Pyrenodesmia vernadskiensis among them. In general, it should be emphasised that the taxonomic status of the newly described species Pyrenodesmia vernadskiensis is still questionable, because no modern description for Huea grisea is available, and there is still no molecular data on this species available. Main diagnostic characters of Huea grisea were mentioned in the original descriptions of Pertusaria grisea by Vainio (1903) and Lecidea coralligera by Hue (1915b) and almost more than 100 years ago. Huea coralligera and $H$. grisea may belong to the Pyrenodesmia clade of the Caloplacoideae, too. However, molecular data on this species are still to be obtained before making official combinations for these taxa. Originally when we have had very small fragments of thalli collected in 2018 it was included with some hesitation in 

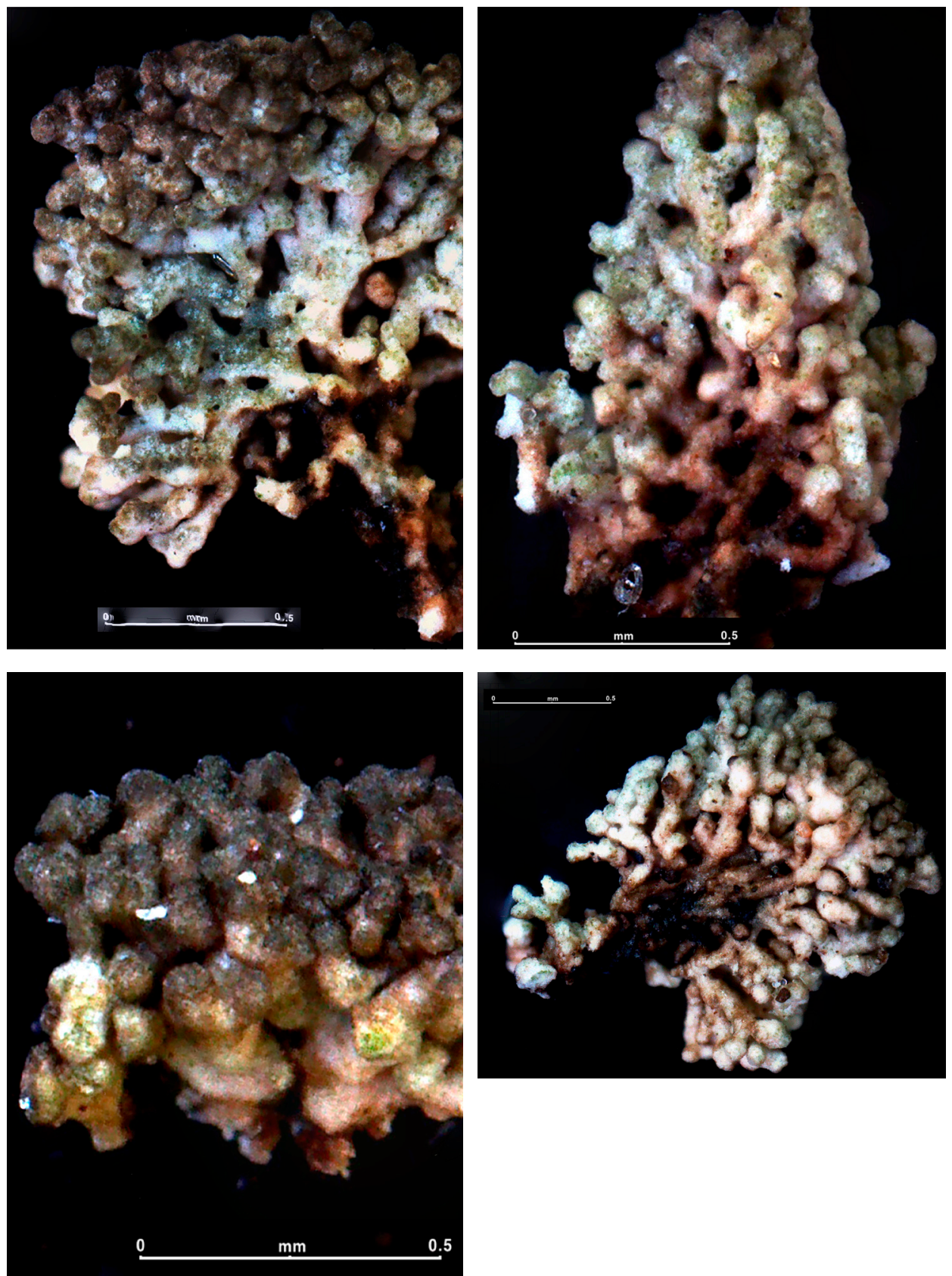

Fig. 17. Pyrenodesmia vernadskiensis (holotype), enlarged thalline filaments. Scales: $0.5 \mathrm{~mm}$ (photo: Kondratyuk, S. Y.) 
Huea coralligera. However, after investigations in the field conditions and getting a richly fertile collection in 2020, as well as after getting molecular data on this species it was confirmed that in the wide range of variation of thallus of Pyrenodesmia vernadskiensis (from richly fertile thallus with well-developed hypothallus at initial stages to bulky microfruticose tufts) the thallus of this species does not include the stage with thick continuous thallus with welldeveloped cortical layer, as it was documented by Vainio and Hue for Huea grisea and $H$. coralligera. However, it should be emphasised that the revision of rich and freshly collected material of Huea grisea with modern methods and molecular study is in urgent need to clarify the status of the Antarctic members of the genus Pyrenodesmia. Genus Pyrenodesmia A. Massal. was proposed in the middle of the 19th century, but it was considered as a synonym of the genus Caloplaca in the premolecular era (Kärnefelt 1989). However, after threegene phylogeny Pyrenodesmia is now accepted as a separate genus of the subfamily Caloplacoideae (Arup et al. 2013, Kondratyuk et al. 2014a, 2015b, 2017a, $2020 a$, etc.). It was a rather different opinion on the status of 'Caloplaca' xerica and 'Caloplaca' teicholyta groups, as well as some more species groups, but it is recently shown that they are still nested within the same Pyrenodesmia clade (Kondratyuk et al. 2020b). Pyrenodesmia vernadskiensis is included in the genus Pyrenodesmia on the basis of molecular phylogeny based on the nrITS sequences, for the first time obtained for the Winter and Galindez specimens within this study. However, we would expect that the further molecular data (i.e. data on $28 \mathrm{~S}$ nrLSU and $12 \mathrm{~S} \mathrm{mtSSU}$, as well as the other genes) will confirm a somewhat isolated position of this Antarctic species from other Pyrenodesmia spp. similarly to the genera Thamnolecania (Vail.) Gyeln. of the Ramalinaceae, Tassiloa S. Y. Kondr. et al. of the Teloschistaceae and others which are characterised by having microfruticose thallus typical for Antarctic material. So, Pyrenodesmia vernadskiensis is similar to the Chilean lichen species Tassiloa digitaurea (Sogaard, Søchting et Sancho) S. Y. Kondr. et al., growing on rock, detritus and other lichens on exposed outcrops in shrub vegetation and grassland, in having fruticose thallus composed of mostly vertical, isidia-like lobes, but differs in having dark brown greyish to light grey or whitish grey thalline filaments (vs. dull yellow-orange to vivid orange), in having black lecideine (vs. zeorine to lecanorine, with yellow-orange thalline margin and dull brownish orange disc), in having bluish epihymenium, $\mathrm{K}$ - (vs. yellowish orange, $\mathrm{K}+$ purple), in having lower hymenium (55-65 $\mu \mathrm{m}$ vs. 60-100 $\mu \mathrm{m}$ high), in having shorter and wider ascospores (11-14 × (6.5-)7.5-9.5 $\mu \mathrm{m}$ vs. (12.5-)13-16(-18) $\times$ $(5-) 6-7.5(-8) \mu \mathrm{m}$, as well as wider ascospore septum $(3.5-) 4-6(-6.5) \mu \mathrm{m}$ vs. (1-)1.5-2.5(-3.5) $\mu \mathrm{m}$ wide), as well as in the lack of anthraquinones (Kondratyuk et al. 2015a, Lumbsch et al. 2011). Pyrenodesmia vernadskiensis is similar to Thamnolecania species, of which 7 species were so far recorded from the Southern Hemisphere (see Kondratyuk et al. 2014d, 2019a, b), but differs in 

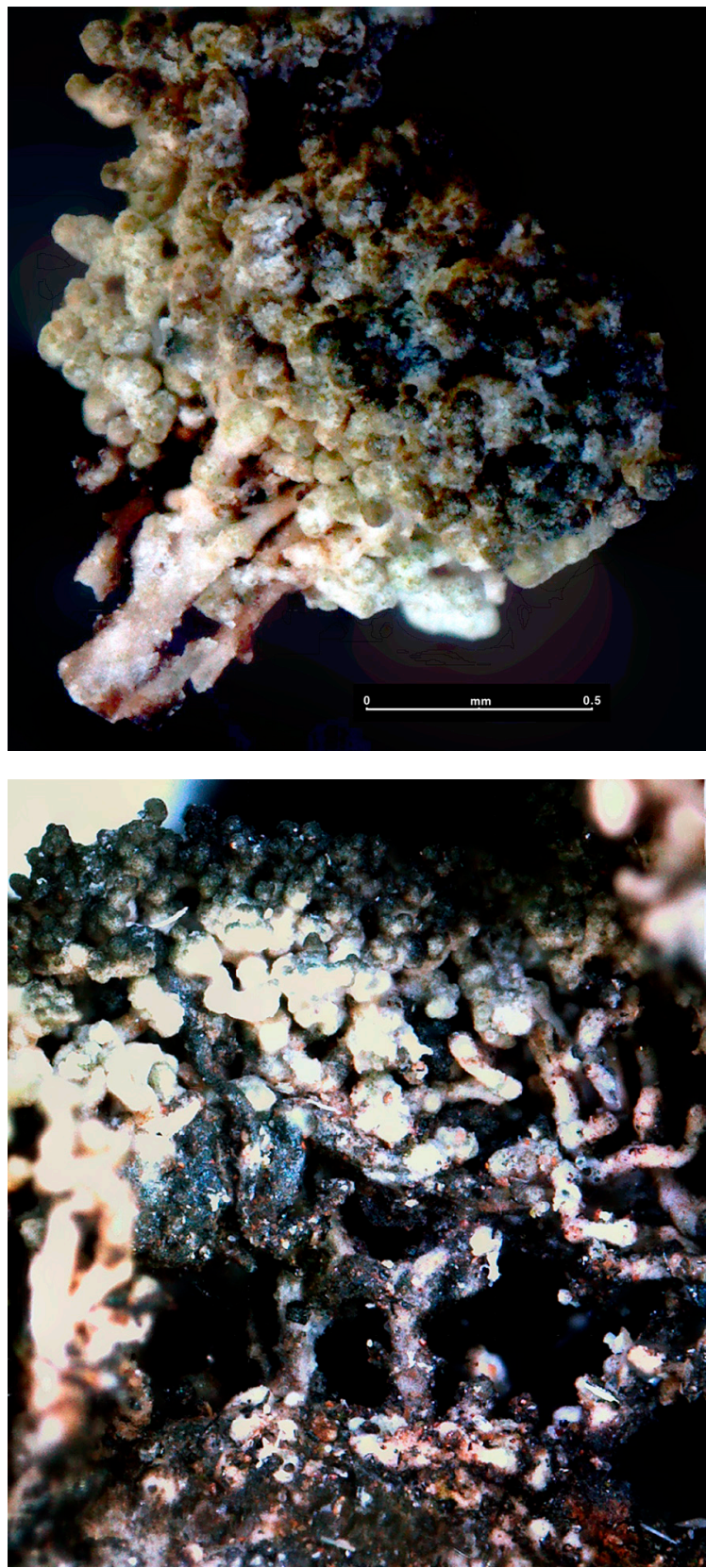

Fig. 18. Pyrenodesmia vernadskiensis (holotype), enlarged thalline filaments. Scale $0.5 \mathrm{~mm}$ (photo: Kondratyuk, S. Y.) having lecideine black (vs. lecanorine with thalline margin concolorous with thallus) apothecia, and in having bipolar ascospores (vs. ascospores 1-septate). Thus, as far as all Antarctic lichens with microfruticose thallus are positioned within separate monophyletic branches, i.e. Thamnolecania (Vail.) Gyeln. in the Lecania s. 1. clade of the Ramalinaceae, Tassiloa in the Teloschistoideae of the Teloschistaceae, maybe Pyrenodesmia vernadskiensis will be segregated as a unique separate branch too in future. However, the first molecular data so far available show that it is still positioned within the $P y$ renodesmia s. str. clade of the Caloplacoideae of the Teloschistaceae. However, we would like to emphasise that it is a temporary place in the Pyrenodesmia (Caloplacoideae) since we hitherto have data on its position in the Pyrenodesmia branch after the nrITS phylogeny only. However, after three-gene phylogeny it maybe positioned in a separate branch, like Tassiloa in Teloschistoideae and Thamnolecania in the Ramalinaceae having the same microfruticose type of thallus. Pyrenodesmia vernadskiensis is similar to Massalongia intricata Øvstedal (Massalongiaceae, 
Peltigerales), a minutely fruticose Antarctic endemic species, having thallus to 2-3 cm wide and $\mathrm{ca} 1 \mathrm{~cm}$ high cushions, composed of ascending, terete, $c a 0.2$ $\mathrm{mm}$ wide, ramified brown lobes, but differs in having green photobiont (vs. cyanobacteria), in having narrower thalline lobes (vs. $0.2 \mathrm{~mm}$ wide), which are only in the upper portion brown (vs. entirely brown), and in having bipolar (vs. 3-4-septate) ascospores. Pyrenodesmia vernadskiensis is similar to the members of the genera Buellia and Lecidea by having black lecideine apothecia, but differs in having blue green hymenium, and in having hyaline and bipolar ascospores (vs. ascospores brown and 1-septate or hyaline and simple consequently).

Other specimens examined: Western coast of Antarctic Peninsula. Argentine Islands, Winter Island, base of old flagstick, on siliceous rock surface, above bryophyte remnants, growing together with Umbilicaria sp. and Caloplaca (Rufoplaca) sp. S 64' $15^{\prime} 16.9^{\prime \prime}, \mathrm{W}^{\circ} 65^{\circ}$ $15^{\prime} 4.2^{\prime \prime}$ [ = S 65.25116 ${ }^{\circ}$, W 64.25469º . Coll.: Parnikoza, I. Y., 07.04.2018 (KW-L sub Umbilicaria sp., paratype, voucher KTA 864A). - Galindez Island, Govorucha dome slope, rock wall, on moss remnants or detritus or even on rock surface, growing together with Usnea antarctica and Umbilicaria sp., Candelariella sp. and Ochrolechia sp. S $64^{\circ} 14^{\prime} 42.1^{\prime \prime}, \mathrm{W} 65^{\circ} 14^{\prime}$ 53.4" [=S 65.248170 ${ }^{\circ}$, W 64.245029º]. Coll.: Parnikoza, I. Y., 08.04.2018 (KW-L, voucher KTA 868A, voucher for DNA SK M06); the same locality, growing together with Protoparmelia sp., Lecanora sp., and Lepraria sp. (KW-L, voucher KTA 866A, voucher for DNA SK M09); the same locality, Galindez Island, Woozle Hill, Govorucha dome slope, rock wall, as small fragments among thalli of Ochrolechia, growing together with Coppinsidea and Lecidea spp. Coll.: Parnikoza, I. Y. (IP5), 02.03.2020 (KW-L sub Coppinsidea sp.).

Rehmanniella poeltiana S. Y. Kondr. et J.-S. Hur, spec. nova (Fig. 19)

MycoBank No.: MB 836740

Similar to Caloplaca johnwhinrayi, but differs in epruinose brownish yelloworange apothecium disc, in having narrower ascospores and distinctly narrower ascospore septum, as well as in the lack of a whitish granular sorediate thallus, and lack of numerous oil cells in the paraphyses.

Type: Chile: Huasco Baja, La Gruta, on sandstone rock, growing together with Massjukiella candelaria, Buellia sp. [white thallus]. Lat.: $28^{\circ} 26^{\prime} 23.4^{\prime \prime}$ S; Long.: $71^{\circ} 11^{\prime} 17.6^{\prime \prime} \mathrm{W}$; Alt.: 12 m a.s.l. Coll.: Oh, S.-O., Hur, J.-S. (CL130445), 13.11.2013 (KoLRI 020581 - holotype, DNA voucher SK H63 and SK J66); the same locality, (CL130447), (KoLRI 020583 - isotype, DNA voucher SK H64).

Thallus to several $\mathrm{cm}$ across, but may form large portions, very indistinct, areolate, very weakly attached to the substrate (easily taken out from the substrate), (lichens are well distinct owing to dull brownish yellow discs of 
more or less aggregated apothecia); areoles $0.3-0.7 \mathrm{~mm}$ across, hardly distinct among apothecia; colour of upper surface very varying from dull greyish or whitish yellow or dull brownish yellow / dirty whitish yellow to dull / dirty yellow often covered by dust particles to dark grey and blackish, in some places more or less with scarce whitish pruina (similar to Caloplaca johnwhinrayi) and somewhat pinkish shade of thalline areoles pink-yellowish whitish (contrasting to apothecium discs). Hypothallus not observed.

Apothecia $0.3-1.0 \mathrm{~mm}$ diam., and to $0.4-0.5 \mathrm{~mm}$ thick in section, mainly regularly rounded at first, then becoming more or less pressed, when aggregated, lecanorine or zeorine; thalline margin rather distinct because brighter than thallus and disc, bright yellow or bright yellow orange to somewhat pinkish yellow whitish in places, where whitish pruina observed, ca $0.1 \mathrm{~mm}$ wide, more or less persistent, entire; thalline exciple with time seen mainly at sides, and differs from true exciple in having whitish incrustations or being whitish to dull whitish yellow; true exciple distinct as whitish circle (seen at $120 \times$ ) or indistinct at all in young apothecia, and becoming more prominent, to $40-50 \mu \mathrm{m}$ wide, bright yellow in the mature and overmature stages; more or less elevated above level of both disc and thalline margin is the brightest portion of apothecium; disc more or less flat, dull brownish yellow-orange (without reddish tinge); in section zeorine, but algal line in horizontal line below true exciple (similar to Xanthocarpia crenulata-type); thalline exciple to $100 \mu \mathrm{m}$ thick, well developed only at sides, cortical layer (15-)20-50(-120) $\mu \mathrm{m}$ thick, of very lax hyphae or with necral layer; algal zone with clusters elongated vertically, 50-100 $\mu \mathrm{m}$ diam./wide; true exciple to $35-40 \mu \mathrm{m}$ thick in the upper lateral portions, $20-25 \mu \mathrm{m}$ thick in lower lateral portion, to 12-15 $\mu \mathrm{m}$ thick or not seen in basal portion, of textura intricata; hymenium 60-70 $\mu \mathrm{m}$ high; epihymenium to $20 \mu \mathrm{m}$ thick, dark brown to orange; subhymenium 100-125 $\mu \mathrm{m}$, without oil; ascospores narrowly fusiform distinctly widened at the septum, 11-13(-14) $\times(3-) 3.5-4.5(-5) \mu \mathrm{m}$; ascospore septum narrow, 2-2.5(-3) $\mu \mathrm{m}$ wide.

Chemistry: Outermost portion of true exciple, epihymenium K+ purple.

Distribution and ecology: It is known so far only from type collection in Chile, South American continent. It grows on rocks together with Massjukiella candelaria, Buellia sp.

Etymology: It is named after the well-known Austrian lichenologist Josef Poelt in recognition of his contribution to the taxonomy of the Teloschistaceae especially.

Taxonomic notes: Rehmanniella poeltiana is characterised by very indistinct areolate thallus with very varying surface from dull greyish or whitish yellow to dark grey or blackish in places with whitish pruina and somewhat pinkish tinge of thalline areoles, lecanorine or zeorine apothecia with bright 

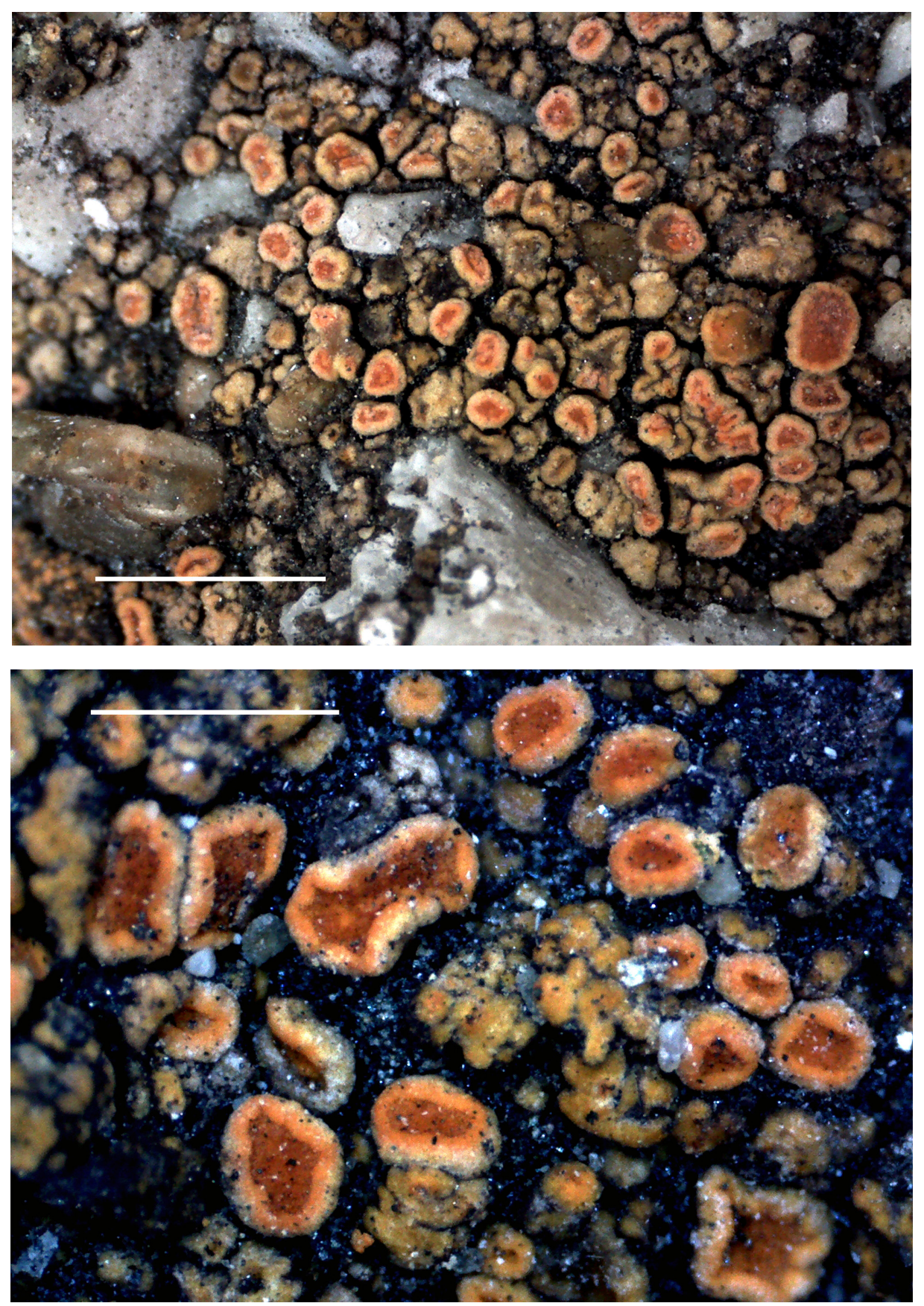

Fig. 19. Rehmanniella poeltiana, general habit (CL130447, isotype) (top), and (CL130445, holotype) (bottom). Scale $1 \mathrm{~mm}$ (photo: Kondratyuk, S. Y.) 
yellow or yellow-orange to somewhat pinkish yellow whitish to dull whitish yellow in places, with whitish pruina thalline margin with time seen only at sides, with whitish to bright yellow circle of true exciple (if developed) and flat dull brownish yellow-orange disc (without reddish tinge). Rehmanniella poeltiana is similar to the Australian lichen Caloplaca johnwhinrayi S. Y. Kondr. et Kärnefelt known from scattered localities in Western Australia, South Australia, Victoria and Tasmania, where it grows on basic coastal rocks, which is similar to the widespread epiphytic Athallia cerinelloides (Erichsen) Arup, Frödén et Søchting, but differs in having epruinose brownish yellow-orange apothecium disc (vs. pink with whitish pruina), in having narrower ascospores $(11-13(-14) \times(3-) 3.5-4.5(-5) \mu \mathrm{m}$ vs. $(11-) 12-14(-17) \times 5.5-7(-8) \mu \mathrm{m})$ and distinctly narrower ascospore septum $(2-2.5(-3) \mu \mathrm{m}$ vs. (5-)6-7(-8) $\mu \mathrm{m}$ wide), as well as in the lack of a whitish granular sorediate thallus, and lack of numerous oil cells in the paraphyses (Kondratyuk et al. 2009b).

Rehmanniella poeltiana is similar to the Australasian Sirenophila maccarthyi (S. Y. Kondr., Kärnefelt et Elix) Arup, Frödén et Søchting currently known from Australia and New Zealand growing on bark and dead wood of trees and shrubs, but differs in having not so aggregated apothecia, in having narrower ascospores $(11-13(-14) \times(3-) 3.5-4.5(-5) \mu \mathrm{m}$ vs. $(8-) 10-14(-15) \times 7-8(-9) \mu \mathrm{m})$ in having narrower ascospore septum $(2-2.5(-3) \mu \mathrm{m}$ vs. $5-7(-8) \mu \mathrm{m}$ wide), as well as in the lack of oil in paraphyses (see Kondratyuk et al. 2009b). Rehmanniella poeltiana is similar to the widespread Northern Hemisphere species Athallia cerinelloides (Erichsen) Arup, Frödén et Søchting, but differs in being saxicolous and in having narrower ascospores (11-13(-14) $\times(3-) 3.5-4.5(-5)$ $\mu \mathrm{m}$ vs. $9-13 \times 5-7 \mu \mathrm{m})$, and in having narrower septum $(2-2.5(-3) \mu \mathrm{m}$ vs. $3-4$ $\mu \mathrm{m}$ wide) and by distribution in the Southern Hemisphere (Kondratyuk et al. 2004). Rehmanniella poeltiana is similar to Flavoplaca kantvilasii (S. Y. Kondr. et Kärnefelt) Arup, Frödén et Søchting, a widely distributed Australian species growing on natural calcicolous rocks and granite outcrops, from coastal to subalpine and dry inland localities as well as on artificial materials too, but differs in having thin areolate thallus (vs. thick and convex areoles forming rosettes), in the lack of reddish colour of apothecia, in having shorter and narrower ascospores $(11-13(-14) \times(3-) 3.5-4.5(-5) \mu \mathrm{m}$ vs. $(6-) 8-17(-21) \times(4.5-)$ $5-7(-8) \mu \mathrm{m})$, and narrower ascospore septum $(2-2.5(-3) \mu \mathrm{m}$ vs. $(2-) 3-6(-8) \mu \mathrm{m}$ thick) (cf. Kondratyuk et al. 2007). After molecular phylogeny of the Teloschistoideae the genus Rehmanniella includes three more taxa known from the Northern and Southern Hemispheres, additionally to the type species of the genus Rehmanniella wirthii described from Africa (Kondratyuk et al. 2017a). After nrITS phylogeny the SE European species Caloplaca syvashica Khodos., Vondrák et Šoun, as well as the Australian lichen Caloplaca subgyalectoides S. 
Y. Kondr. et Kärnefelt* both belong to the Rehmanniella branch.** This is why two new combinations, i.e. Rehmanniella subgyalectoides and R. syvashica are proposed here in this paper [see below]. Two sets of data were submitted for Australian Caloplaca yarraensis S. Y. Kondr. et Kärnefelt, recent name Cerothallia yarraensis (S. Y. Kondr. et Kärnefelt) S. Y. Kondr. et al. After molecular data submitted for Cerothallia yarraensis by Arup et al. (2013) and Kondratyuk et al. (2014c) this species is positioned in the Xanthorioideae in the Cerothallia branch, based on nrITS and on combined (three-gene phylogeny) data. At the same time data submitted by Vondrák and colleagues (Vondrák et al. 2012) for C. yarraensis are positioned in the Teloschistoideae and in fact these data are quite different from real C. yarraensis. Vondrák's data are based on the study of specimens collected by us in Australia and distributed in exsiccate set in various herbaria. This species was described by Kondratyuk et al. (2009b), and herbarium specimens which were used as voucher specimens by Vondrák were collected in field conditions in Australia by us, and they were prepared and distributed as exsiccate set by us, too. On the basis of our knowledge of this collection we have the following suggestion. Data of Vondrák and colleagues (Vondrák et al. 2012), i.e. nrITS sequences with GenBank accession numbers JF826399 and JF826398 for Cerothallia yarraensis (as well as NR_119962 for Cerothallia yarraensis too) may belong to Caloplaca subgyalectoides S. Y. Kondr. et Kärnefelt, which grows side by side with Cerothallia yarraensis in the Australian collection (Kondratyuk et al. 2013b). Caloplaca subgyalectoides was described from the same set, which was prepared for distribution. These two taxa often grow together and they were distributed in the same set. This is why we may suggest that Vondrák's data belong to Caloplaca subgyalectoides, and this species is proposed for new combination to the genus Rehmanniella. Rehmanniella leucoxantha (Müll. Arg.) S. Y. Kondr. is proposed here, too, based exclusively on $12 \mathrm{~S}$ mtSSU phylogeny of the Teloschistaceae. It should be confirmed with data on nrITS and nrLSU sequences in the future, too.

Other specimen examined: Chile: La Higuera, Caleta De Hornos, on seashells, growing together with Massjukiella candelaria, Athallia cf. holocarpa and Buellia sp. Lat.: $29^{\circ} 37^{\prime}$ 21.4" S; Long.: 71 17' 28.4" W; Alt.: 25 m a.s.l. Coll.: Oh, S.-O., Hur, J.-S. (CL130383), 12.11.2013 (KoLRI 020517). It is included here with some hesitation.

\footnotetext{
* Rehmanniella subgyalectoides is proposed here very preliminarily for the following reason.

** There is one more species of this genus hitherto known to us from South America, Peru. Formal description of this new species of the genus Rehmanniella from South America will be published in a separate publication.
} 
Rufoplaca aesanensis S. Y. Kondr. et J.-S. Hur, spec. nova (Fig. 20)

MycoBank No.: MB 836741

Similar to Rufoplaca oxfordensis, but differs in having smaller apothecia becoming convex and Biatora-like in overmature state, in having shorter ascospores, and in having wider septum.

Type: Republic of Korea, Kangwon-do, Jeongseon-gun, Jeongseon-eup, Aesan-ri, Jeongseon church, on limestone, growing together with Psora sp., Psorotichia sp., and Collema sp., where Rufoplaca aesanensis damaged by Intralichen christiansenii (D. Hawksw.) D. Hawksw. et M. S. Cole. Lat.: $37^{\circ} 22^{\prime}$ 17.3" N; Long.: $128^{\circ} 40^{\prime} 25.2^{\prime \prime}$ E; Alt.: 319 m a.s.l. Coll.: Lee, B. G. (152792-2) (or 152792.2), 06.09.2015 (KoLRI 038293 - holotype).

Thallus crustose, indistinctly areolate, dull dark grey or brownish grey to $2 \mathrm{~cm}$ across with extremely small and indistinct, dull yellow apothecia. Areoles $0.15-0.3 \mathrm{~mm}$ across (seen at $120 \times$ ) seen at edge of thallus, in the centre more or less continuous, cracks to $20-40 \mu \mathrm{m}$ wide, rock surface not seen, dull dark grey or dull brownish grey. Thallus to (80-)100-120(-130) $\mu$ m thick in section, cortical layer to 10-15 $\mu \mathrm{m}$ thick, with outermost layer to 10-13 $\mu \mathrm{m}$ thick, slightly greyish or brownish, cells $3-4 \mu \mathrm{m}$ diam., mostly of 1-2 layers of cells, and lower portion with much larger cells, to 8-11(-15) $\mu \mathrm{m}$ across, or vertically elongated or rounded, algal cells (10-)15-19 $\mu \mathrm{m}$. Algal zone to (50-)80-100 $\mu \mathrm{m}$ thick, where algae are positioned among paraplectenchymatous tissue; almost entire layer of crystals to $7-10 \mu \mathrm{m}$ across is present below thallus. Prothallus absent.

Apothecia (0.1-)0.15-0.3(-0.4) mm diam., very small, dull yellow at first immersed, then becoming sessile, lecanorine (seem to be biatorine), at first plane and later becoming subconvex or very convex, disc and own margin concolorous, dull yellow-orange, but when becoming convex becoming Lecanora- or Biatora-like, dull brown and emarginate. In section apothecia 0.15$0.18 \mathrm{~mm}$ thick, lecanorine or zeorine, thalline exciple to $40(-70) \mu \mathrm{m}$ thick, algal cells 15-20 $\mu \mathrm{m}$ diam.; true exciple 30-40(-50) $\mu \mathrm{m}$ thick in the uppermost lateral portion and 10-15 $\mu \mathrm{m}$ thick in lower lateral and basal portion, paraplectenchymatous, cells rounded to 5-6 $\mu \mathrm{m}$ across; hymenium (50-)60-70(-80) $\mu \mathrm{m}$ high; paraphysis tips rounded to $4-6 \mu \mathrm{m}$ diam., slightly brownish in water, colourless in K; subhymenium 40-50 $\mu \mathrm{m}$ thick, hyaline, without oil, paraplectenchymatous sensu Wetmore; asci 8-spored, usually numerous and with adult ascospores of various size within the same ascus; ascospores (8-)10-11 $(-13) \times(4-) 5-6 \mu \mathrm{m}$ in water, 10-12 ×5-6(-6.5) $\mu \mathrm{m}$ in K; ascospore septum 3-5 $\mu \mathrm{m}$ wide in water and (3-)4.5-6(-6.5) $\mu \mathrm{m}$ wide in $\mathrm{K}$. 

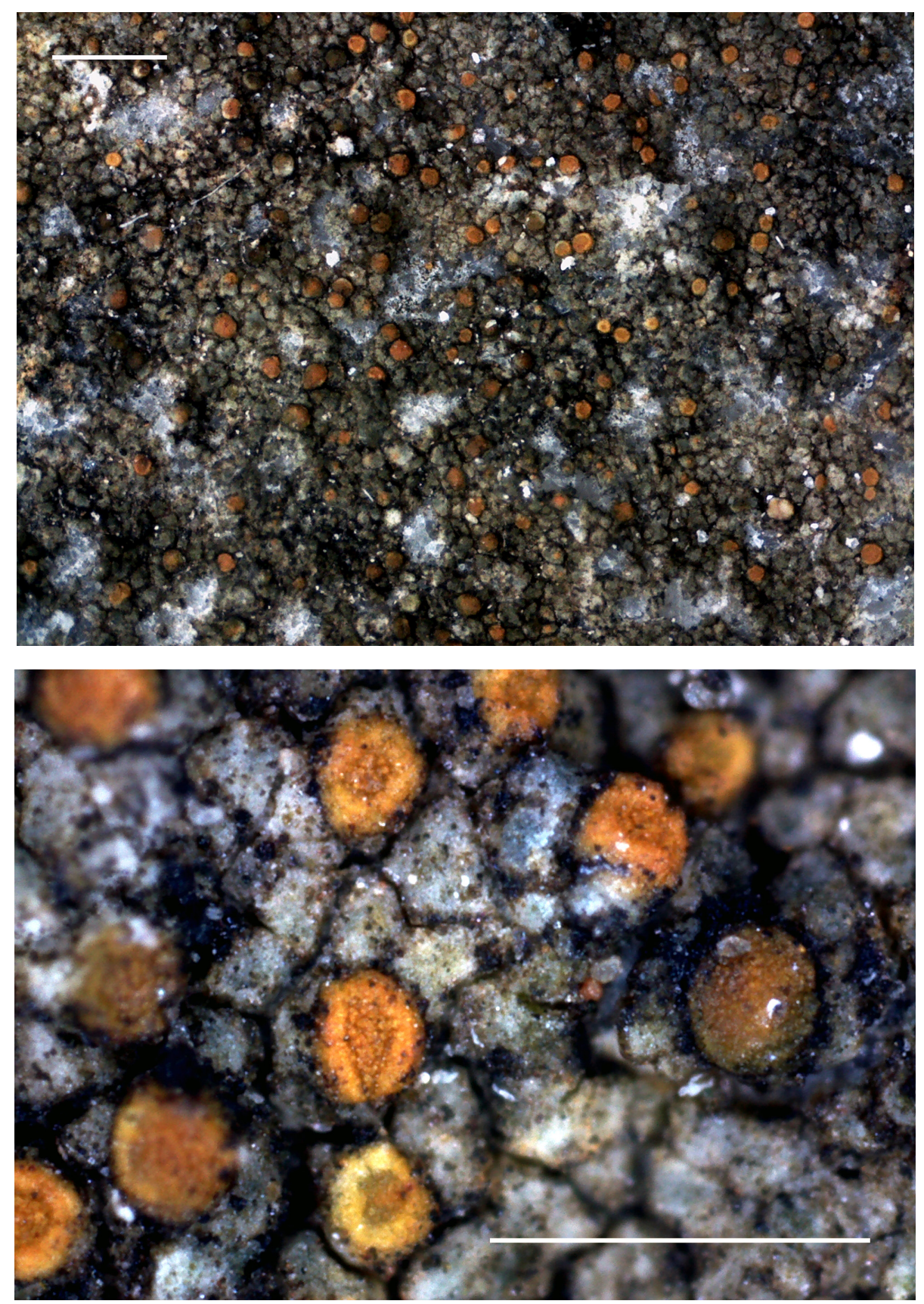

Fig. 20. Rufoplaca aesanensis (151792_2, holotype), general habit. Scale 1 mm (photo: Kondratyuk, S. Y.) 
Chemistry: Thallus $\mathrm{K}-$, thalline cortical layer $\mathrm{K}-$, epihymenium $\mathrm{K}+$ purple or violetish purple and uppermost portion of true exciple in lateral portion $\mathrm{K}+$ violet.

Etymology: It is named after type locality, Aesan locality of South Korea, Eastern Asia.

Distribution and ecology: It is so far known only from scattered localities in South Korea, Eastern Asia. It grows on limestone together with various crustose lichens, i.e. Psora sp., Psorotichia sp., and Collema sp., where Rufoplaca aesanensis damaged by Intralichen christiansenii (D. Hawksw.) D. Hawksw. et M. S. Cole.

Taxonomic notes: Rufoplaca aesanensis is similar to R. oxfordensis (Fink) Arup, Søchting et Frödén, but differs in having smaller apothecia becoming convex and Biatora-like in overmature state $(0.15-0.3 \mathrm{~mm}$ vs. $0.3-0.7 \mathrm{~mm}$ diam.), in having shorter ascospores ((8-)10-11(-13) $\times(4-) 5-6 \mu \mathrm{m}$ vs. (11-)12$15(-16) \times(4-) 5-7) \mu \mathrm{m})$, and in having wider septum ( $3-5 \mu \mathrm{m}$ vs. $2-3 \mu \mathrm{m}$ wide) (cf. Kondratyuk et al. 2004). Rufoplaca aesanensis is similar to Caloplaca atroflava (Turner) Mong., but differs in having lecanorine and smaller apothecia becoming convex and Biatora-like in overmature state $(0.15-0.3 \mathrm{~mm}$ vs. biatorine, $0.3-0.6 \mathrm{~mm}$ diam.), in having better developed thalline exciple, in having much wider apical cells of paraphyses (4-6 $\mu \mathrm{m}$ vs. to $3 \mu \mathrm{m})$, and in having shorter and narrower ascospores $((8-) 10-11(-13) \times(4-) 5-6 \mu \mathrm{m}$ vs. (9-)11-13 $(-17) \times(5.5-) 7-9(-10)) \mu \mathrm{m})($ cf. Kondratyuk et al. 2004).

Other specimen examined: Republic of Korea, Chungcheongbuk-do, Danyang-gun, Danyang-eup, Nodong-ri, Danyangnodong-gil, on limestone. Lat.: $36^{\circ} 58^{\prime} 46.9^{\prime \prime} \mathrm{N}$; Long.: $128^{\circ} 22^{\prime}$ 26.2" E; Alt.: 137 m a.s.l. Coll.: Woo, J. J. (152820), 05.09.2015 (KoLRI 037129 sub Caloplaca sp.).

Squamulea coreana S. Y. Kondr. et J.-S. Hur, spec. nova (Figs 21-22)

MycoBank No.: MB 836742

Similar to Squamulea squamosa, S. subsoluta and S. parviloba, but differs in having complex squamules consisting of densely aggregated or overlapping smaller single areoles, in having narrower ascospores, and in having wider ascospore septum, as well as in having whitish hypothallus.

Type: Republic of Korea: Jeju-do, Jeju-si, Hangyeong-myeon, Sinchang-ri, around Singaemul Park nearby coast, on rock. Lat.: $33^{\circ} 20^{\prime} 31.91^{\prime \prime}$ N; Long.: $126^{\circ} 10^{\prime} 13.00^{\prime \prime}$ E; Alt.: $2 \mathrm{~m}$ a.s.l. Coll.: Kondratyuk, S. Y., Lőkös, L., Oh, S.-O., Jayalal, U., Joshi, S., Park, J.-S., Hur, J.-S. (121560), 05.07.2012 (KoLRI 016606 sub Squamulea - holotype); the same locality, (121587, 121842), KoLRI 016633, KoLRI 016733 - isotypes); the same locality, growing with Ramalina 
sp. damaged by lichenicolous fungus, Pyxine, and Buellia spp. (121551), (KoLRI 016597 sub Squamulea - isotype, voucher of Squamulea coreana for DNA extraction); the same locality, growing together with Anaptychia isidiata Tomin, Phaeophyscia sp., Buellia subhalonia, Buellia sp., Diploschistes sp., (121561), (KoLRI 016607 sub Squamulea - isotype, voucher of Squamulea coreana for DNA extraction); the same locality, growing together with Myriospora sp. and Verrucaria sp., (121584), (KoLRI 016630 sub Squamulea - isotype, voucher of Squamulea coreana for DNA extraction); the same locality, growing together with Mikhtomia multicolor (121575), (KoLRI 016621 sub Mikhtomia multicolor - isotype, voucher of Squamulea coreana for DNA extraction SK 652).

Thallus to $2-5 \mathrm{~cm}$ across, forming rounded or ellipsoid spots, areolate to squamulose, at first crustose and consisting of very small areoles, $0.2-0.3(-0.4)$ $\mathrm{mm}$ across, then squamulose; complex areoles and squamules (1-)1.2-2 $\mathrm{mm}$ across, rather uplifted above substrate level, more or less subconvex, upper surface bright brownish yellow or dull yellow, consisting of microlobules or small areoles $0.2-0.3(-0.5) \mathrm{mm}$ across overlapping one another; very small outgrowths or overgrowing portions (0.1-)0.2-0.3(-0.4) $\mathrm{mm}$ across, elongated or divided, ovoid, better seen at the margin, but sometimes and in the centre of thalline areoles; cracks between areoles to $0.2-0.4 \mathrm{~mm}$ wide, rock surface seen at large magnification; often microlobules at edges of squamules slightly lighter in colour to whitish, with short to $10 \mu \mathrm{m}$ long, scarce white hyphae, and give the impression of being thinner or with white hypothallus; thalline lobes / squamules in section (120-)180-230 $\mu \mathrm{m}$ thick and $0.3(-0.35) \mathrm{mm}$ wide in section; cortical layer of thallus rather thin, to (7-)20-25 $\mu \mathrm{m}$ thick, cell lumina to 4-9 $\mu \mathrm{m}$ diam./across, cells are rather thick walled; usually the whole cavity of thallus filled in by algal cells or algal zone 100-120 $\mu$ m thick often throughout paraplectenchymatous. Hypothallus whitish (or lower side or underside white).

Apothecia (0.2-)0.4-0.9(-1.5) $\mathrm{mm}$ diam., immersed at first in thalline portions, and seem to be biatorine, then more or less sessile and lecanorine or zeorine, while very often they seem to be biatorine; often aggregated 2-4(-6) per group, at $120 \times$ zeorine, thalline margin dull brownish yellow or greenish yellow, variegated, $0.04-0.1 \mathrm{~mm}$ wide disappearing in places; sometimes covered by overgrowing microlobules to $0.5 \mathrm{~mm}$ across; disc plane dull brownish orange to dark brown orange; own margin if different to $40-80 \mu \mathrm{m}$ wide, usually slightly lighter than disc, as dull yellow orange circle around disc, somewhat pinkish brownish orange often very indistinct and almost concolorous with disc (seen at 120×); thalline margin to $0.1-0.15 \mathrm{~mm}$ wide, dull yellow or dull brownish yellow, sometimes with microlobules; sometimes crenulate, or seen only at basis; apothecium, to $0.3-0.35 \mathrm{~mm}$ thick in section, zeorine in section; thalline exciple to 50-100(-200) $\mu \mathrm{m}$ thick, cortical layer to 20-30 $\mu \mathrm{m}$ thick in basal portion/underside of apothecium, cell lumina (5-)9-12(-15) $\mu \mathrm{m}$ across; algal cells to (8-)15-20 $\mu \mathrm{m}$; true exciple $70-80 \mu \mathrm{m}$ thick in the upper- 

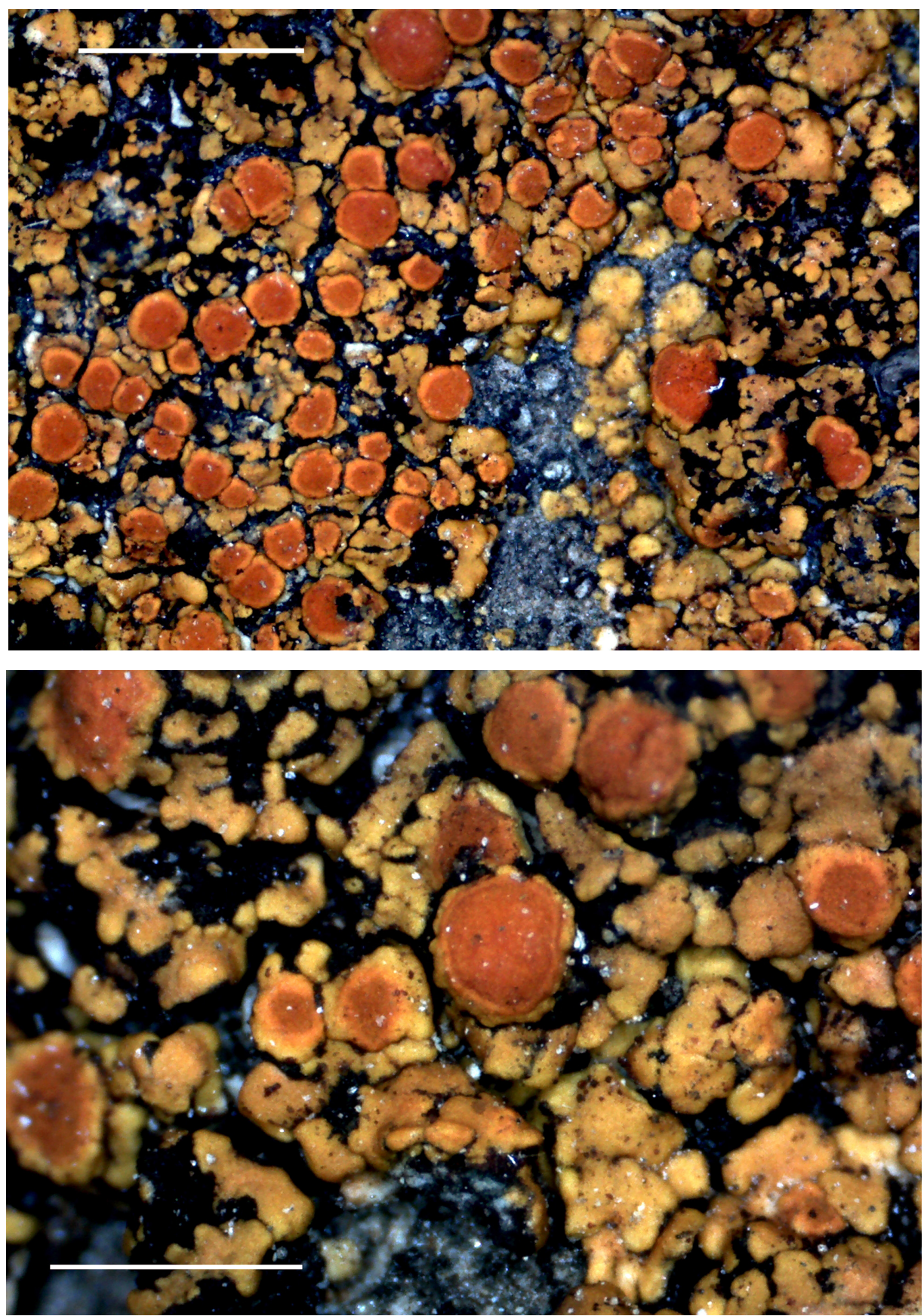

Fig. 21. Squamulea coreana (121560, holotype), general habit (top), enlarged portion of thallus with apothecia (bottom). Scale $2 \mathrm{~mm}$ (top) and $1 \mathrm{~mm}$ (bottom) (photo: Kondratyuk, S. Y.) 

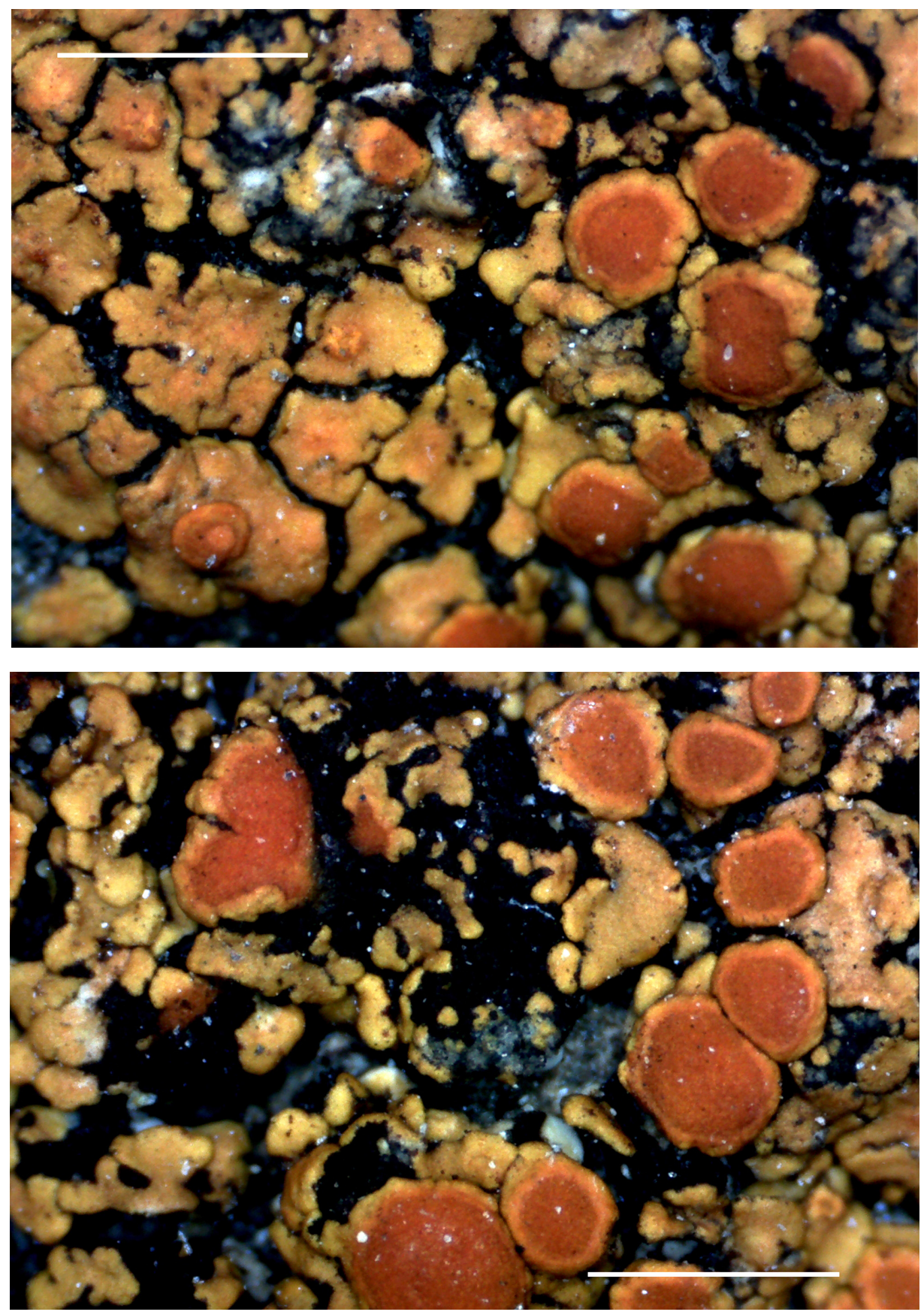

Fig. 22. Squamulea coreana (121560, holotype), enlarged portion of thallus with apothecia. Scale $1 \mathrm{~mm}$ (photo: Kondratyuk, S. Y.) 
most lateral portion, 20-30 $\mu \mathrm{m}$ thick in lower lateral portion, paraplectenchymatous with cell lumina, $7-9(-10) \mu \mathrm{m}$ across or to $13 \times 8 \mu \mathrm{m}$, sometimes cells are rather thick walled; to (50-)70-80 $\mu \mathrm{m}$ thick in basal portion, paraplectenchymatous, cells with lumina 1.5-3 $\mu \mathrm{m}$ across; hymenium (60-)70-80 $\mu \mathrm{m}$ high; paraphysis tips to (2.5-)4-5 $\mu \mathrm{m}$ diam. in K; subhymenium (40-)50100(-120) $\mu \mathrm{m}$ thick, without oil droplets, probably paraplectenchymatous sensu Wetmore; ascospores with more or less rounded ends and widened at the septum, in K becoming almost spherical, (8-)9-13(-14) × (3.5-)5-6(-7) $\mu \mathrm{m}$ in water $(\mathrm{n}=58)$ and $(8-) 10-13(-15) \times(4-) 5-8(-10) \mu \mathrm{m}$ in $\mathrm{K}(\mathrm{n}=72)$, ascospore septum (2-)3-5(-6) $\mu \mathrm{m}$ wide in water and (2-)4-6(-6.5) $\mu \mathrm{m}$ wide in K. Conidiomata rounded to $150-170 \mu \mathrm{m}$ diam., immersed, mainly indistinct. Conidia bacilliform, (2.5-)3-3.5(-4) × 0.9-1 $\mu \mathrm{m}$.

Etymology: It is named after the country where it was collected, i.e. South Korea, Eastern Asia.

Distribution and ecology: It is so far known from scattered localities in mainland and on islands of archipelago of South Korea, Eastern Asia. It grows on siliceous rocks in coastal zone and in mainland.

Taxonomic notes: Species is characterised by having somewhat dissected or microfragments or microscopic outgrowths on the upper surface, not even, and in having small areoles within the same thallus at first distant, then aggregated to areolate with small horizontally orientated scales or lobules, very varying within one thallus and from thallus to thallus, while in section thalline squamule consisting of very small areoles $c a 0.3(-0.35) \mathrm{mm}$ wide, as well as in having biatorine-like apothecia, which at higher magnification are zeorine, in having whitish hypothallus, as well as in having small 9-13 $\times 5-6 \mu \mathrm{m}$ and rather wide septum (3-5 $\mu \mathrm{m})$. Squamulea coreana is similar to $S$. squamosa (B. de Lesd.) Arup, Søchting et Frödén, S. subsoluta (Nyl.) Arup, Søchting et Frödén and S. parviloba (Wetmore) Arup, Søchting et Frödén, but differs in having complex squamules consisting of densely aggregated or overlapping smaller single areoles. Furthermore, it differs from S. squamosa and S. subsoluta in having somewhat narrower ascospores $((8-) 9-13(-14) \times(3.5-) 5-6(-7)$ $\mu \mathrm{m}$ vs. 9.5-14.0 × 5.5-7.0 $\mu \mathrm{m})$, and in having somewhat wider septum $((2-) 3-5$ vs. 3-4 $\mu \mathrm{m}$ wide), as well as in having whitish hypothallus (after Wetmore 2003). Squamulea coreana is similar to S. parviloba in having squamule with small overgrowing portions $(0.2-0.3(-0.4) \mathrm{mm}$ across), but differs in having much larger apothecia ((0.2-) $0.4-1.5 \mathrm{~mm}$ diam. vs. $0.2-0.5 \mathrm{~mm}$ diam.), in having squamulose (vs. areolate to subsquamulose) thallus, and in having much larger thalline squamules. Squamulea coreana is similar to $S$. squamosa after squamulose type of thallus and lecanorine apothecia, while based on molecular data (i.e. nrITS phylogeny) it is positioned in the Squamulea subsoluta subclade of the genus Squamulea. 
Other specimens examined: Republic of Korea: Gyeongsangbuk-do, Ulleung-do Island, Ulleung-gun, Ulleung-eup, Dodong-ri, Dodong Port. Lat.: 37²8' 59.9" N; Long.: $130^{\circ}$ 54' 40.7" E; Alt.: 20 m a.s.l. Coll.: Kondratyuk, S. Y., Lőkös, L. (162032), 11.07.2016 (KoLRI 040270 sub Squamulea, voucher of Squamulea coreana SK H42 for DNA extraction); Ulleungdo Island, Ulleung-gun, Seo-myeon, Taeha-ri, on siliceous rocks along tourist path. Lat.: $37^{\circ} 30^{\prime} 48.46^{\prime \prime}$ N; Long.: $130^{\circ} 48^{\prime}$ 0.05” E; Alt.: 85 m a.s.l. Coll.: Kondratyuk, S. Y., Lőkös, L. (170451), 02.06.2017 (KoLRI 044575 sub Squamulea). - Jeju-do, Mt Halla, on rock. Lat.: 33 22' 20.5" N; Long.: $126^{\circ}$ 52' 42.4" E; Alt.: 1 m a.s.l. Coll.: n.a. (061009), 17.10.2006 (KoLRI 005393 sub Squamulea, voucher of Squamulea coreana for DNA extraction); Jeju-do, Jeju-si, Hangyeong-myeon, Sinchang-ri, around Singaemul Park nearby coast, on rock. Lat.: $33^{\circ}$ 30' 31.3" N; Long.: $126^{\circ} 10^{\prime} 13.1^{\prime \prime}$ E; Alt.: 19 m a.s.l. Coll.: Kondratyuk, S. Y., Lőkös, L., Oh, S.-O., Jayalal, U., Joshi, S., Park, J.-S., Hur, J.-S. (121380), 05.07.2012 (KoLRI 016438 sub Squamulea); Jeju-do, Jeju-si, Hangyeong-myeon, Sinchang-ri, seashore road, on rock. Lat.: $33^{\circ} 20^{\prime}$ 31.6" N; Long.: $126^{\circ} 10^{\prime} 12.08^{\prime \prime}$ E; Alt.: 82 m a.s.l. Coll.: Joshi, Y., So, J.-E. (140170), 18.06.2014 (KoLRI 022538 sub Squamulea); Jeju-do, Seogwipo-si, Namwon-eup, Wimi-ri, on rock. Lat.: 3316' 13.3" N; Long.: $126^{\circ} 39^{\prime} 30.0^{\prime \prime}$ E; Alt.: 10 m a.s.l. Coll.: Kondratyuk, S. Y., Lőkös, L., Oh, S.-O., Jayalal, U., Joshi, S., Park, J.-S., Hur, J.-S. (091413), 29.05.2009 (KoLRI 011056 sub Squamulea, voucher of Squamulea coreana SK 687 for DNA extraction); the same locality, on rock, growing with Loekoesia austrocoreana, damaged by Polycoccum aff. innatum (Müll. Arg.) D. Hawksw. and Psorotichia sp., (091424), (KoLRI 011067 sub Loekoesia austrocoreana); Jejudo, Seogwipo-si, Seongsan-eup, Seopjikoji-ro, Seopjikoji, on rock, growing together with

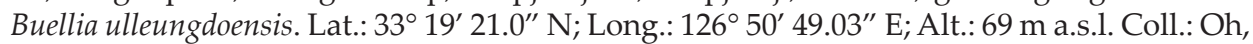
S.-O., Park, J. S., Hur, J.-S. (140525), 19.06.2014 (KoLRI 022920 sub Squamulea).

\section{New combinations}

Massjukiella impolita (Arup) S. Y. Kondr., comb. nova - MycoBank No.: MB 836743 - Basionym: Caloplaca impolita Arup, Bryologist 98(1): 101 (1995). $\equiv$ Polycauliona impolita (Arup) Arup, Frödén et Søchting, Nordic J. Bot. 31(1): 52 (2013).

Massjukiella pollinarioides (L. Lindblom et D. M. Wright) S. Y. Kondr., comb. nova - MycoBank No.: MB 836744 - Basionym: Xanthoria pollinarioides L. Lindblom et D. M. Wright, Lichen Flora of the Greater Sonoran Desert Region (Tempe) 2: 608 (2004). झ Polycauliona pollinarioides (L.) Lindblom et D. M. Wright) Frödén, Arup et Søchting, in Arup et al., Nordic J. Bot. 31(1): 53 (2013).

Massjukiella stellata (Wetmore et Kärnefelt) S. Y. Kondr., comb. nova - MycoBank No.: MB 836745 - Basionym: Caloplaca stellata Wetmore et Kärnefelt, Bryologist 101(2): 246 (1998). $\equiv$ Polycauliona stellata (Wetmore et Kärnefelt) Arup, Frödén et Søchting, Nordic J. Bot. 31(1): 53 (2013).

Massjukiella tenax (L. Lindblom) S. Y. Kondr., comb. nova - MycoBank No.: MB 836746 - Basionym: Xanthoria tenax L. Lindblom, J. Hattori bot. Lab. 83: 158 (1997). 三 Polycauliona tenax (L. Lindblom) Frödén, Arup et Søchting, in Arup et al., Nordic J. Bot. 31(1): 53 (2013).

Massjukiella tenuiloba (L. Lindblom) S. Y. Kondr., comb. nova - MycoBank No.: MB 836747 - Basionym: Xanthoria tenuiloba L. Lindblom, Mycotaxon 80: 376 (2001). झ Polycauliona tenuiloba (L. Lindblom) Frödén, Arup et Søchting, in Arup et al., Nordic J. Bot. 31(1): 53 (2013). 
Pyrenodesmia albopruinosa (Arnold) S. Y. Kondr., comb. nova-MycoBank No.: MB 836748 - Basionym: Biatorina albopruinosa Arnold, Flora, Regensburg 42: 152 (1859). इCaloplaca albopruinosa (Arnold) H. Olivier, Mém. Soc. natn. Sci. nat. Cherbourg 37: 147 (1909).

Pyrenodesmia ceracea (J. R. Laundon) S. Y. Kondr., comb. nova-MycoBank No.: MB 836749 - Basionym: Caloplaca ceracea J. R. Laundon, Lichenologist 24(1): 4 (1992).

Pyrenodesmia cretensis (Zahlbr.) S. Y. Kondr., comb. nova - MycoBank No.: MB 836750 - Basionym: Blastenia cretensis Zahlbr., Sber. Akad. Wiss. Wien, Math.-naturw. Kl., Abt. 1, 115: 519 (1906). $\equiv$ Caloplaca cretensis (Zahlbr.) Wunder, in Vězda, Lich. Selecti Exs. (Průhonice) 40, no. 996 (1971).

Pyrenodesmia erythrocarpa (Pers.) S. Y. Kondr., comb. nova - MycoBank No.: MB 836751 - Basionym: Patellaria erythrocarpa Pers., Ann. Wetter. Gesellsch. Ges. Naturk. 2: 12 (1811) [1810]. झ Caloplaca erythrocarpa (Pers.) Zwackh [as 'erythrocarpia'], Flora, Regensburg 45: 487 (1862).

Pyrenodesmia haematites (Chaub. ex St. Amans) S. Y. Kondr., comb. nova - MycoBank No.: MB 836752 - Basionym: Lecanora haematites Chaub. ex St.-Amans, Fl. agen.: 492 (1821). $\equiv$ Caloplaca haematites (Chaub. ex St.-Amans) Zwackh, Flora, Regensburg 45: 487 (1862).

Pyrenodesmia percrocata (Arnold) S. Y. Kondr., comb. nova - MycoBank No.: MB 836753 - Basionym: Blastenia percrocata Arnold, Verh. zool.-bot. Ges. Wien 37: 120 (1887). ” Caloplaca percrocata (Arnold) J. Steiner, in Halácsy, Denkschr. Kaiserl. Akad. Wiss., Math.naturw. K1. 61: 523 (1894).

Pyrenodesmia soralifera (Vondrák et Hrouzek) S. Y. Kondr., comb. nova-MycoBank No.: MB 836754 - Basionym: Caloplaca soralifera Vondrák et Hrouzek, Graphis Scripta 18(1): 8 (2006).

Pyrenodesmia transcaspica (Nyl.) S. Y. Kondr., comb. nova - MycoBank No.: MB 836755 - Basionym: Lecanora transcaspica Nyl., in Brotherus, Öfvers. Finska Vetensk.-Soc. Förh. 40: 9 (1897). = Caloplaca transcaspica (Nyl.) Zahlbr., Cat. Lich. Univ. 7: 189 (1931).

Pyrenodesmia viridirufa (Ach.) S. Y. Kondr., comb. nova - MycoBank No.: MB 836756 - Basionym: Lecidea viridirufa Ach., Lich. univ.: 204 (1810). झ Caloplaca viridirufa (Ach.) Zahlbr., Cat. Lich. Univ. 7: 198 (1931). = Parmelia aractina Fr., Syst. orb. veg. (Lundae) 1: 284 (1825). $\equiv$ Caloplaca aractina (Fr.) Häyrén, Landveg. Flor. Meeresfels. Tvärminne: 152 (1914). = Caloplaca ferruginea var. fuscoatra Decuillé, Bull. Soc. Étud. Sci. d'Angers 22: 223 (1893) [1892].

Pyrenodesmia xerica (Poelt et Vězda) S. Y. Kondr., comb. nova - MycoBank No.: MB 836757 - Basionym: Caloplaca xerica Poelt et Vězda, Mitt. bot. StSamml., Münch. 12: 1 (1975).

Rehmanniella leucoxantha (Müll. Arg.) S. Y. Kondr., comb. nova-MycoBank No.: MB 836758 - Basionym: Amphiloma leucoxanthum Müll. Arg., Flora, Regensburg 71: 139 (1888) = Caloplaca syvashica (Müll. Arg.) Zahlbr., Cat. Lich. Univ. 7: 242 (1931).

Rehmanniella syvashica (Khodos., Vondrák et Šoun) S. Y. Kondr., comb. nova - MycoBank No.: MB 836759 - Basionym: Caloplaca syvashica Khodos., Vondrák et Šoun, in Vondrák et al., Lichenologist 44(1): 85 (2011) [2012].

Rehmanniella subgyalectoides (S. Y. Kondr. et Kärnefelt) S. Y. Kondr., comb. nova MycoBank No.: MB 836760 - Basionym: Caloplaca subgyalectoides S. Y. Kondr. et Kärnefelt, in Kondratyuk et al., Folia Crypt. Estonica 50: 46 (2013). 


\section{Rare species \\ (! = new for South America; ${ }^{*}=$ new for Republic of Korea)}

Agonimia blumii S. Y. Kondr. - Republic of Korea, Gyeongsangbuk-do, Ulleung-do Island, Ulleung-gun, Ulleung-eup, between Naesujeon and Seokpo waterfall, on siliceous rock, growing together with Lepraria sp. Lat.: $37^{\circ} 31^{\prime} 29.41^{\prime \prime} \mathrm{N}$; Long.: $130^{\circ} 54^{\prime} 13.08^{\prime \prime}$ E; Alt.: 395 m a.s.l. Coll.: Kondratyuk, S. Y., Lőkös, L. (170370), 31.05.2017 (KoLRI 044494 sub Agonimia). - New localities for the recently described species (Kondratyuk 2015).

Athallia aff. pyracea (Ach.) Arup, Frödén et Søchting - Republic of Korea, Gyeongsangbuk-do, Uljin-gun, Jukbyeon-myeon, Jukbyeon-ri, Jukbyeon10-gil, roadside trees along street Jukbyeonjungang-ro, on bark of Cerasus sp., and Metasequoia glyptostroboides, growing together with Rinodina convexula, Hyperphyscia sp. Lat.: $37^{\circ} 03^{\prime} 27.19^{\prime \prime} \mathrm{N}$; Long.: $129^{\circ}$ 25’ 03.82" E; Alt.: 10 m a.s.l. Coll.: Kondratyuk, S. (SK-102), Lőkös, L. (151360), 11.07.2015 (KoLRI 034593 sub Athallia cf. pyracea). - The Korean specimen differs from Athallia pyracea (Ach.) Arup, Frödén et Søchting in having better developed thalline exciple, in having to 80 $\mu \mathrm{m}$ thick, lax algal zone, in having very large to $20-25(-28) \mu \mathrm{m}$ diam. algal cells, in having narrower ascospores $((11-) 12-14(-15) \times 5-6.5(-8) \mu \mathrm{m}(\mathrm{n}=26)$ in water and $(10-) 11-14(-15)$ $\times(4.5-) 5.5-7(-10) \mu \mathrm{m}$ in $\mathrm{K}(\mathrm{n}=38)$ vs. $11-14 \times 6-8 \mu \mathrm{m})$, and in having wider ascospore septum $(5-7 \mu \mathrm{m}$ wide in water, $5-8 \mu \mathrm{m}$ wide in $\mathrm{K}$, vs. 3-6 $\mu \mathrm{m})$. It is possibly another species of the Athallia pyracea aggr.

! Buelliella inops (Triebel et Rambold) Hafellner - Chile: Cuesta Bvenos ayres, on rock, on lichen thalli of Follmannia orthoclada and Teuvoahtiana rugulosa (in parts) damaged by Buelliella inops as well as Zwackhiomyces aff. berengerianus. Lat.: $29^{\circ} 35^{\prime} 11.7^{\prime \prime}$ S; Long.: 71' 14' 52.9" W; Alt.: 257 m a.s.l. Coll.: Oh, S.-O., Hur, J.-S. (CL130409), 13.11.2013 (KoLRI 020543 sub Follmannia orthoclada, DNA voucher of F. orthoclada SK H94, SK J76). - Chile: La Higuera, Caleta De Hornos, on rock, on thallus of F. orthoclada. Lat.: 29 37' 21.4" S; Long.: 71' 17' 28.4" W; Alt.: 25 m a.s.l. Coll.: Oh, S.-O., Hur, J.-S. (CL130381), 12.11.2013 (KoLRI 020515 sub F. orthoclada, voucher for DNA SK H95). - New to South America! Buelliella inops is for the first time recorded from Follmannia orthoclada and Teuvoahtiana rugulosa.

Caloplaca cf. kedrovopadensis S. Y. Kondr. et Hur - Republic of Korea, Gyeongsangbuk-do, Ulleung-do Island, Ulleung-gun, Seo-myeon, Taeha-ri, on siliceous rocks along tourist path. Lat.: $37^{\circ} 30^{\prime} 48.46^{\prime \prime}$ N; Long.: $130^{\circ} 48^{\prime}$ 0.05" E; Alt.: 85 m a.s.l. Coll.: Kondratyuk, S. Y., Lőkös, L. (170456), 02.06.2017 (KoLRI 044580 sub Caloplaca kedrovopadensis). New locality for the recently described species (Kondratyuk et al. 2014b).

*Caloplaca poliotera (Nyl.) J. Steiner (Fig. 23) - Republic of Korea, Gangwon-do, Samcheok-si, Geundeok-myeon, Gungchon-ri, Gungshon Seashore, on rock, growing together with Psorotichia gyelnikii. Lat.: $37^{\circ} 19^{\prime} 41.4^{\prime \prime}$ N; Long.: 129 16' 21.1" E; Alt.: 43 m a.s.l. Coll.: Park, J. S. (151839), 11.07.2015 (KoLRI 034842 sub Squamulea); Jeonam Prov., Jindo Co, seaside, on rock, growing together with Yoshimuria galbina. Lat.: $34^{\circ} 32.919^{\prime}$ N; Long.: $126^{\circ}$ 18.694' E; Alt.: 2 m a.s.l. Coll.: n.a. (110483), 03.06.2011 (KoLRI 013528 sub Yoshimuria galbina). - Since unfortunately no modern description of Caloplaca poliotera is available we provide a description based on Korean specimens. Thallus to $10 \mathrm{~cm}$ across or more, crustose, areolate, grey to light grey. Thalline areoles $(0.2-) 0.4-1.4(-1.5) \mathrm{mm}$ across, scattered in peripheral zone and densely aggregated towards the centre, cracks between areoles to $60 \mu \mathrm{m}$ wide, rock surface not seen (at 120×), more or less plane/flat, but sometimes becoming somewhat convex and overlapping each other. Hypothallus black, sometimes well developed, 0.3-1.3 $\mathrm{mm}$ wide in peripheral zone, often seen between scattered areoles too. Apothecia (0.2-)0.3$0.75 \mathrm{~mm}$ diam., more or less immersed at first, then sessile, biatorine or zeorine (at $120 \times$ 

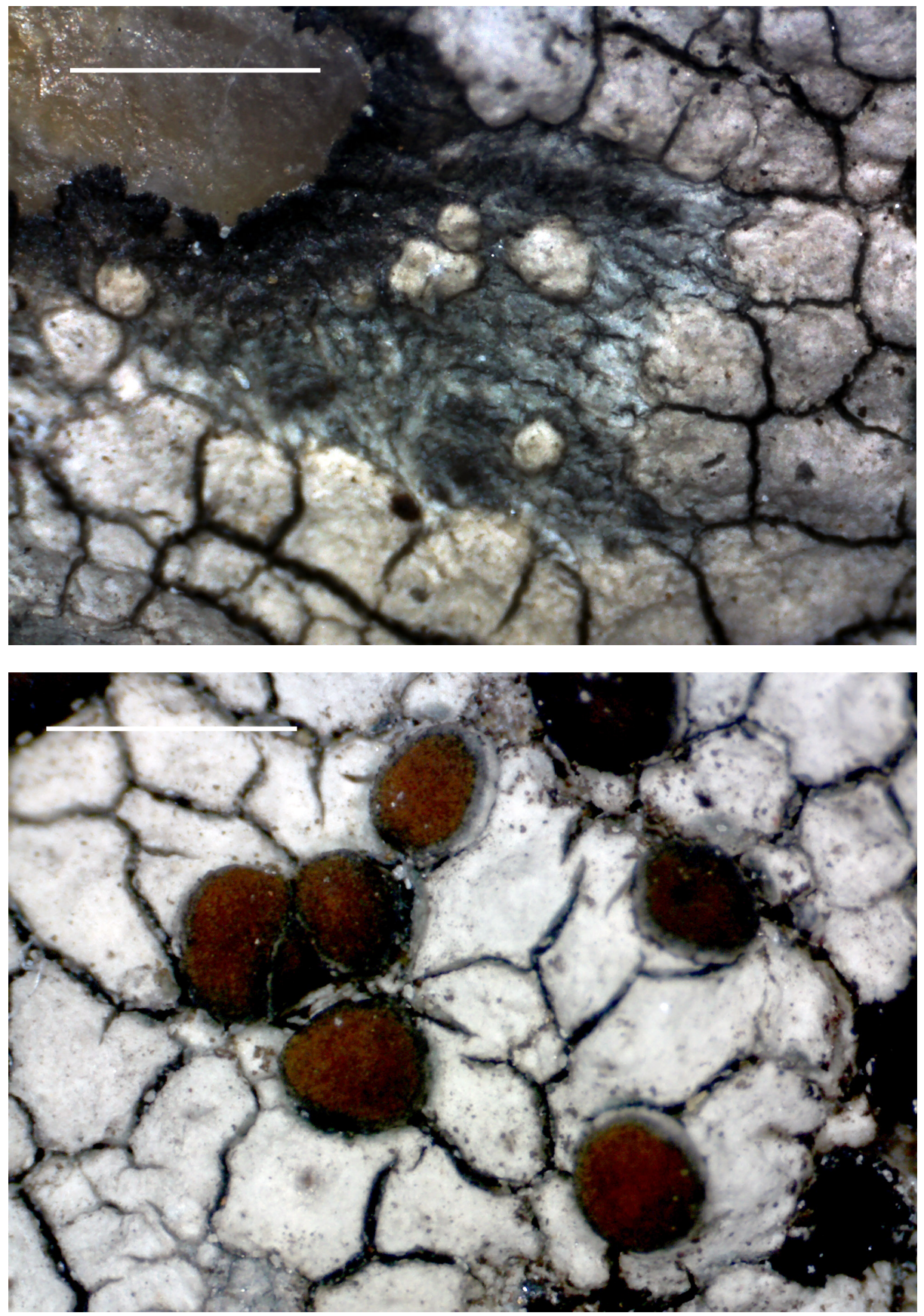

Fig. 23. Caloplaca poliotera (151839), enlarged portion with hypothallus and thalline areoles (top), enlarged portion with apothecia (bottom). Scale $1 \mathrm{~mm}$ (photo: Kondratyuk, S. Y.) 
magnification); disc dark brown, to blackish brown, flat, own margin blackish or greyish black, to 50-60 $\mu \mathrm{m}$ wide (seen at 120×); thalline margin seen at sides or thalline margin seen at basis of apothecia grey or dark grey. In section apothecium to $0.3-0.35 \mathrm{~mm}$ thick, zeorine, thalline margin to 80-90 $\mu \mathrm{m}$ thick, cortical layer 20-30 $\mu \mathrm{m}$ thick, paraplectenchymatous, greyish of crystals/air bubbles; true exciple to 90-100(-120) $\mu \mathrm{m}$ wide in the uppermost lateral portion, blackish brown, paraplectenchymatous, cell lumina to 5-6 $\mu \mathrm{m}$ across, to 30-40 $\mu \mathrm{m}$ thick in the lower lateral portion, and to (20-)30-50(-70) $\mu \mathrm{m}$ thick in basal portion, paraplectenchymatous or lax plectenchymatous; hymenium to $60 \mu \mathrm{m}$ high; epihymenium to $20 \mu \mathrm{m}$ thick, dark brown; paraphysis tips to 5-6 $\mu \mathrm{m}$ diam., uppermost cells to 5-6 $\mu \mathrm{m}$ diam. (in water or 5-6 $\mu \mathrm{m}$ diam. in K), dark brown; subhymenium to (70-)80-130 $\mu \mathrm{m}$ thick or more; asci to $45 \times 12 \mu \mathrm{m}, 8$-spored; ascospores rather small and narrow, (9-)10-12(-13) $\times(3-) 3.5-5(-6.5) \mu \mathrm{m}$ in water and (8-)9-13(-15) $\times 4-6(-7) \mu \mathrm{m}$ in $\mathrm{K}$, and ascospore septum $(2-) 3-4(-6) \mu \mathrm{m}$ wide in water, and to $(2.5-) 3-6(-7) \mu \mathrm{m}$ wide. Chemistry: Cortical layer $\mathrm{K}+$ weak yellow, while in section $\mathrm{K}+$ dull purple/pink, $\mathrm{C}+$ pink, $\mathrm{Pd}-$; medulla $\mathrm{C}+$ pink, $\mathrm{Pd}-$. Thalline exciple and outermost true exciple (black or dark brown portion) $\mathrm{K}-, \mathrm{KC}+$ pink and disappearing, while $\mathrm{K}+$ reaction of epihymenium not disappearing. Probably gyrophoric acid (in algal zone especially) present. The Korean specimens may belong to different species like Caloplaca poliotera, because in section thalline exciple of the Korean specimens (both cortical layer and algal zone), as well as upper most portion of true exciple C+ dirty pink, while epihymenium $\mathrm{C}-$. In the original description of $\mathrm{C}$. poliotera the epihymenium is $\mathrm{C}+$ purple and later disappearing reaction. - New to Republic of Korea!

Candelariella makarevichiae S. Y. Kondr., L. Lőkös et Hur - Republic of Korea, Jejudo, Jeju-si, Ecoforest, on bark (and siliceous rocks). Lat.: 33 $25^{\prime}$ 51.31" N; Long.: $126^{\circ} 35^{\prime}$ 56.23" E; Alt.: 594 m a.s.l. Coll.: Kondratyuk, S. Y., Kondratiuk, T. O., Yang, J.-H. (170171), 15.03.2017 (KoLRI 044295 sub Candelariella). - New locality for the recently described species (Kondratyuk et al. 2018). Candelariella subsquamulosa D. Liu et Hur described recently by Liu et al. (2019) is a new synonym of this species (see Kondratyuk et al. 2020c).

Halecania santessonii M. P. Andreev - Republic of Korea, Gyeongsangbuk-do, Ulleung-do Island, Ulleung-gun, Ulleung-eup, between Naesujeon and Seokpo waterfall, on siliceous rock, growing on thalli of Pertusaria sp. Lat.: $37^{\circ} 31^{\prime} 29.41^{\prime \prime} \mathrm{N}$; Long.: $130^{\circ} 54^{\prime}$ 13.08" E; Alt.: 395 m a.s.l. Coll.: Kondratyuk, S. Y., Lőkös, L. (170353), 31.05.2017 (KoLRI 044477 sub H. santessonii); the same locality, (170376), (KoLRI $044500 \mathrm{sub}$ H. santessonii). Additional record to several former Korean localities (Kondratyuk et al. 2016b, 2017b).

Huriella pohangensis S. Y. Kondr., L. Lőkös et Hur - Republic of Korea, Gyeongsangnam-do, Pohang, Nam-gu, Guryongpo-eup, Guryongpo-ri, on siliceous seashore rock, growing together with Flavoplaca sp. Lat.: $35^{\circ} 59^{\prime} 39.36^{\prime \prime} \mathrm{N}$; Long.: $129^{\circ} 33^{\prime}$ 59.91" E; Alt.: 5 m a.s.l. Coll.: Kondratyuk, S. Y., Lőkös, L. (170241), 29.05.2017 (KoLRI 044365 sub Flavoplaca); the same locality, (170242), (KoLRI 044366 sub Flavoplaca); Gyeongsangbuk-do, Ulleung-gun, Ulleung-eup, between Naesujeon and Seokpo waterfall, on rock, growing together with Jonaspis and Lecania. Lat.: $37^{\circ} 31^{\prime} 12.58^{\prime \prime}$ N; Long.: $130^{\circ} 54^{\prime} 12.71^{\prime \prime}$ E; Alt.: 340 m a.s.l. Coll.: Kondratyuk, S. Y., Lőkös, L. (161685), 09.07.2016 (KoLRI 039903 sub Huriella); Jeju-do, Jeju-si, Chuja-do, Chuja-myeon, Yecho-ri, Mt Dondae, on asbestos roof. Lat.: $33^{\circ}$ 56' 53.9” N; Long.: 126 19' 26.7” E; Alt.: 164 m a.s.l. Coll.: Kondratyuk, S. Y., Lőkös, L. (140801), 20.06.2014 (KoLRI 023281); the same place, on asbestos roof, growing together with Flavoplaca flavocitrina and Phaeophyscia sp. Lat.: 33 56'34.75" N; Long.: $126^{\circ} 19^{\prime} 17.46^{\prime \prime}$ E; Alt.: 35 m a.s.l. Coll.: Kondratyuk, S. Y., Lőkös, L. (140813), 20.06.2014 (KoLRI 023298 sub Huriella); Jeju-do, Seogwipo-si, Seongsan-eup, Goseong-ri, Seopjicoji, on rock. Lat.: $33^{\circ} 19^{\prime}$ 21.0" N; Long.: $126^{\circ}$ 50' 49.03" E; Alt.: 69 m a.s.l. Coll.: Joshi, Y., So, J.-E. (140465), 19.06.2014 (KoLRI 022866); the same locality, (140470), (KoLRI 022871); the same locality, growing 
with Neobrownliella salyangensis and Endocarpon sp. (140477), (KoLRI 022878 sub Huriella pohangensis); Jeollanam-do, Goheung-gun, Yeongnam-myeon, Ucheon-ri, Yongam village, Yongbawi seaside, on rock. Lat.: $34^{\circ} 35^{\prime} 40.93^{\prime \prime}$ N; Long.: $127^{\circ} 30^{\prime} 19.41^{\prime \prime}$ E; Alt.: $10 \mathrm{~m}$ a.s.1. Coll.: n.a. (100352), 19.02.2010 (KoLRI 011861). - New localities for the recently described species (Kondratyuk et al. 2018).

Huriella salyangiana S. Y. Kondr. et Hur (Fig. 24) - Republic of Korea: Gyeongnam Prov., Tongyeong City, Salyang Island. Lat.: $34^{\circ} 50.555^{\prime} \mathrm{N}$; Long.: $128^{\circ} 12.179^{\prime}$ E; Alt.: ca $25 \mathrm{~m}$ a.s.l. Coll.: Wang, X. Y., Joshi Y., Han J. H. (110011), 20.04.2011 (holotype: KoLRI 012954 sub Lecidella enteroleucella). - Illustrations of this species, not provided in original publication (Kondratyuk et al. 2018), are included here. As far in 2018 Neobrownliella salyangensis was studied in the same specimen (110011 KoLRI) differences of Huriella salyangiana and Neobrownliella salyangensis are provided here, too. The thallus of Huriella salyangiana differs from Neobrownliella salyangensis, which grows side by side with this species, in having much thicker, more or less convex thalline areoles, as well as in having sessile apothecia.

Lobothallia gangwondoana S. Y. Kondr., J. J. Woo et J.-S. Hur - Republic of Korea, Jeollanam-do, Sinan-gun, Bigeum-myeon, Mt Sunwang, Bigeum-do, on siliceous rock, growing together with Aspicilia cinerea aggr. Lat.: $34^{\circ} 44^{\prime} 13.7^{\prime \prime} \mathrm{N}$; Long.: $125^{\circ} 55^{\prime} 54.05^{\prime \prime} \mathrm{E}$ Alt.: 55 m a.s.l. Coll.: Oh, S.-O., Park, J.-S., Woo, J. J. (130141), 05.06.2013 (KoLRI 018481 sub Aspicilia). - New locality for the recently described species (Kondratyuk et al. 2020a).

Porpidia ulleungdoensis S. Y. Kondr., L. Lőkös et J. P. Halda - Republic of Korea, Gyeongsangbuk-do, Ulleung-do Island, Ulleung-gun, Ulleung-eup, between Naesujeon and Seokpo waterfall, on siliceous rock. Lat.: $37^{\circ} 31^{\prime} 23.14^{\prime \prime} \mathrm{N}$; Long.: $130^{\circ} 54^{\prime} 11.99^{\prime \prime}$ E; Alt.: 480 m a.s.l. Coll.: Kondratyuk, S. Y., Lőkös, L. (170384), 31.05.2017 (KoLRI 044508 sub Porpidia). - New locality for the recently described species (Kondratyuk et al. 2019a).

Psorotichia gyelnikii S. Y. Kondr., L. Lőkös et Hur - Republic of Korea, Gangwondo, Samcheok-si, Geundeok-myeon, Gungchon-ri, Gungshon seashore, on rock, growing together with Caloplaca poliotera. Lat.: $37^{\circ} 19^{\prime} 41.4^{\prime \prime}$ N; Long.: $129^{\circ} 16^{\prime} 21.1^{\prime \prime}$ E; Alt.: $43 \mathrm{~m}$ a.s.1. Coll.: Park, J. S. (151839), 11.07.2015 (KoLRI 034842 sub Caloplaca). - New locality for the recently described species (Kondratyuk et al. 2016b).

${ }^{*}$ Rinodina convexula H. Magn. - Republic of Korea, Gyeongsangbuk-do, Uljin-gun, Jukbyeon-myeon, Jukbyeon-ri, Jukbyeon10-gil, roadside trees along street Jukbyeonjungang-ro, on bark of Cerasus sp., and Metasequoia glyptostroboides, growing together with Athallia cf. pyracea, Hyperphyscia sp. Lat.: $37^{\circ} 03^{\prime} 27.19^{\prime \prime}$ N; Long.: $129^{\circ} 25^{\prime} 03.82^{\prime \prime}$ E; Alt.: 10 m a.s.l. Coll.: Kondratyuk, S. (SK-102), Lőkös, L. (151360), 11.07.2015 (KoLRI 034593 sub Athallia cf. pyracea). - New to Korea!

Rinodina aff. gennarii Bagl. - Republic of Korea, Gyeongsangbuk-do, Ulleung-do Island, Ulleung-gun, Seo-myeon, Taeha-ri, Forest Reserve, on siliceous rock, growing together with Caloplaca sp. Lat.: $37^{\circ} 29^{\prime} 44.69^{\prime \prime}$ N; Long.: $130^{\circ} 49^{\prime} 36.42^{\prime \prime}$ E; Alt.: 375 m a.s.l. Coll.: Kondratyuk, S. Y., Lőkös, L. (170254), 30.05.2017 (KoLRI 044378 sub Caloplaca); Gyeongsangbuk-do, Ulleung-do Island, Ulleung-gun, Ulleung-eup, between Naesujeon and Seokpo waterfall, on siliceous rock, growing together with Yoshimuria aff. spodoplaca. Lat.: $37^{\circ}$ 31' 29.41" N; Long.: 130 54' 13.08” E; Alt.: 395 m a.s.l. Coll.: Kondratyuk, S. Y., Lőkös, L. (170337), 31.05.2017 (KoLRI 044461 sub Yoshimuria aff. spodoplaca). - The Korean material differs from original description of $R$. gennarii in having longer and wider ascospores $((15-) 18-21(-23) \times(7.5-) 10-12 \mu \mathrm{m}$ vs. 13-16 × 7-10 $\mu \mathrm{m}$ after Sheard et al. (2017) or 11-16 × 6-9 $\mu \mathrm{m}$ after Wirth et al. (2013)). - New localities for this rare species in South Korea.

${ }^{*}$ Rinodina kozukensis (Vain.) Zahlbr. - Republic of Korea, Gyeongsangbuk-do, Ulleung-do Island, Ulleung-gun, Ulleung-eup, between Naesujeon and Seokpo waterfall, on siliceous rock. Lat.: $37^{\circ} 31^{\prime} 29.41^{\prime \prime}$ N; Long.: $130^{\circ} 54^{\prime} 13.08^{\prime \prime}$ E; Alt.: 395 m a.s.l. Coll.: 

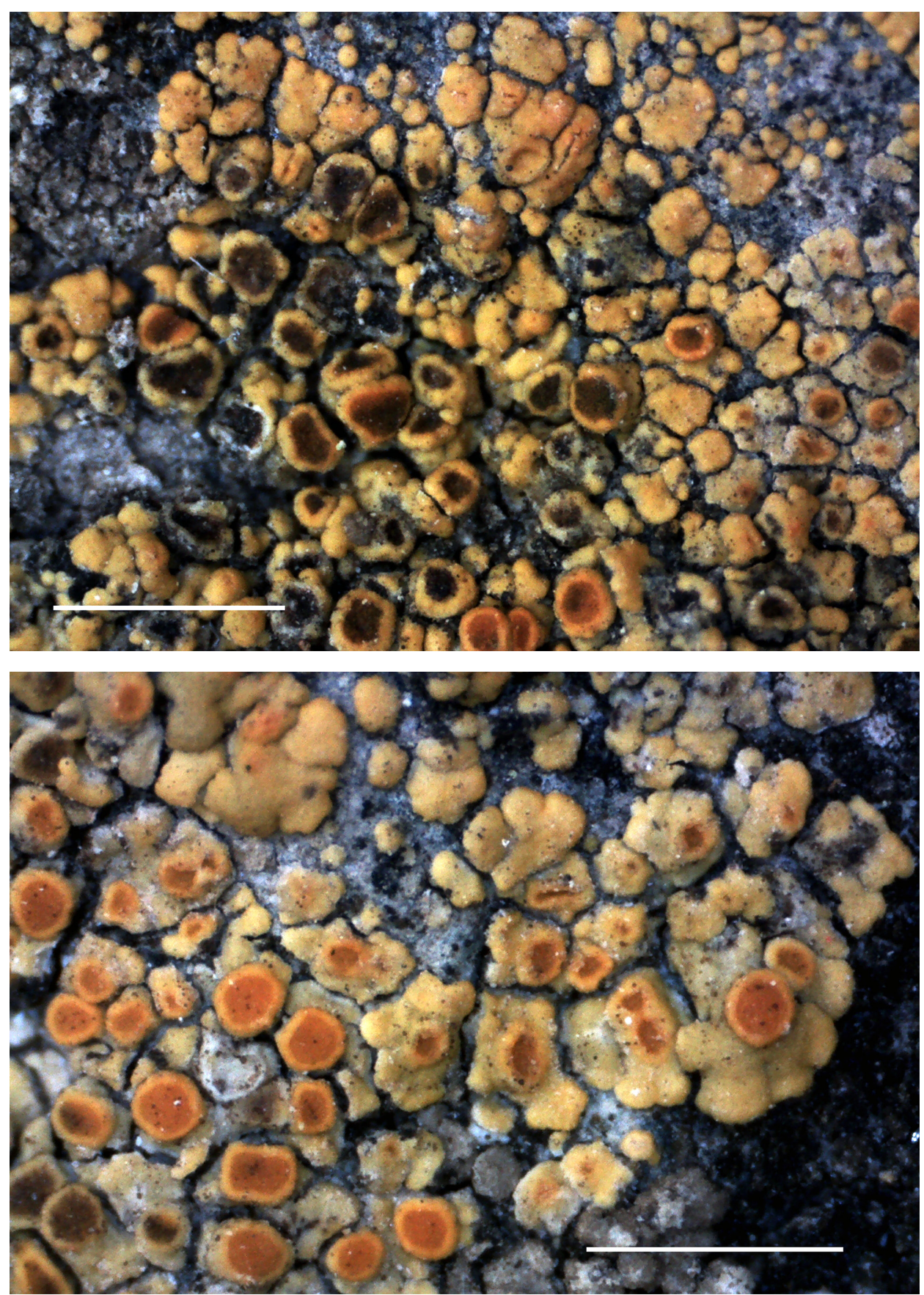

Fig. 24. Huriella salyangiana (110011, holotype), general habit. Scale 1 mm (photo: Kondratyuk, S. Y.) 
Kondratyuk, S. Y., Lőkös, L. (170359, 170360, 170361, 170362), 31.05 .2017 (KoLRI 044483, KoLRI 044484, KoLRI 044485, KoLRI 044486 sub Rinodina). - Thallus 1-3 cm across or in larger aggregations, very thin, areolate, cracked into areole-like portions, the edge of which somewhat exfoliated and uplifted above substrate level resulting in impressions that black hypothallus were present; areoles from very small $0.5 \mathrm{~mm}$ across and more distant and very distinct to (0.8-)1.0-2.0 mm across, irregularly in cracks between areoles to $0.1 \mathrm{~mm}$ wide, while $0.2-0.4 \mathrm{~mm}$ in peripheral zone; upper surface uneven, often with scarce/indistinct blastidia 60-80 $\mu \mathrm{m}$ diam./across, sometimes soredia-like in places, on upper surface of areoles or at their edges; sometimes they become isidious and dark brownish; thalline areole whitish grey to dull greyish; blastidia/soredia usually whitish grey. Hypothallus absent. Apothecia 0.3-0.5(-0.7) $\mathrm{mm}$ diam., to $0.25-0.3 \mathrm{~mm}$ thick in section, scattered, distant, regularly rounded, sometimes becoming subconvex or convex, lecanorine or biatorine if convex where thalline margin seen only at large magnification (at 120×) or disappearing, at first closely attached to the thallus, then somewhat uplifted, subconvex where thalline margin more or less closely attached to the thalline areoles, thalline margin permanent 0.08 $\mathrm{mm}$ wide concolorous with thallus dull grey; true exciple to $40-50 \mu \mathrm{m}$ wide seen between thalline margin and dark brown or shiny chestnut brown disc as lighter dull brown circle seen only at the highest magnification (120×); in section thalline exciple to 50-70 $\mu \mathrm{m}$ thick, cortical layer very narrow 5-7 $\mu \mathrm{m}$ thick, paraplectenchymatous, algal cells $8-15 \mu \mathrm{m}$ diam.; true exciple 30-50 $\mu \mathrm{m}$ thick in the uppermost lateral portion and 10-20 $\mu \mathrm{m}$ thick in lower lateral and basal portion or disappearing in basal portion; hymenium 50-70 $\mu \mathrm{m}$ high; epihymenium to $15 \mu \mathrm{m}$ thick, yellowish brown; paraphysis tips to 3-4.5 $\mu \mathrm{m}$ diam., sometimes with caps to $3 \mu \mathrm{m}$ diam., uppermost cells to 10-15 $\mu \mathrm{m}$ long especially brownish, richly branched, sometimes hook-shaped bent; subhymenium 100-130(-170) $\mu$ m thick, dull straw; ascospores 1(-3)-septate, elongated and narrow, (12-)16-24(-25) × (5.5-)8-11(-12) $\mu \mathrm{m}$. It should be mentioned that the Korean material differs from original description of Melanaspicilia kozukensis Vain. in having longer and somewhat narrower ascospores ((12-) 16-24(-25) × (5.5-)8-11(-12) um vs. 17-18 × 10-12 um of Melanaspicilia kozukensis Vain. according to Vainio 1921) and may illustrate that the Korean material belong to another species. Rinodina kozukensis is similar to Lecania coreana S. Y. Kondr., Lőkös et Hur and L. rinodinoides S. Y. Kondr., Lőkös et Hur in having disc brownish or dull brownish to bright and shiny chestnut brown. However, it differs in having dark ascospores. When apothecia of Rinodina kozukensis are shiny chestnut brown and convex, this lichen can be similar to Protoparmelia species (especially P. oleagina (Harm.) Coppins). However, it differs in having dull grey thallus and in having dark, 1-septate ascospores. After having blastidia (or isidia-like formation) Rinodina kozukensis is similar to the Korean endemic Caloplaca coreana S. Y. Kondr. et J.-S. Hur. However, it differs in having dull grey thallus and in having dark, 1-septate ascospores, as well as in the lack of anthraquinones. - New to Republic of Korea!

Rinodina moziana (Nyl.) Zahlbr. - Republic of Korea, Gyeongsangbuk-do, Ulleunggun, Ulleung-eup, Dodong-ri, Dodong Port, on rock, growing together with Rufoplaca kaernefeltiana, Squamulea coreana, damaged by lichenicolous fungus Bryostigma sp., Caloplaca subconcilians, Phaeophyscia sp., and Aspicilia contorta. Lat.: $37^{\circ} 28^{\prime} 59.9^{\prime \prime}$ N; Long.: $130^{\circ}$ 54' 40.7" E; Alt.: 20 m a.s.l., Coll.: Kondratyuk, S. Y., Lőkös, L. (162031), 11.07.2016 (KoLRI 040269 sub Rufoplaca). * It was reported from Republic of Korea by Sheard et al. (2017). New to Ulleung-do Island!

\footnotetext{
* Originally this specimen was identified as $R$. destituta (Nyl.) Zahlbr. before. However, now it is considered as a synonym of $R$. moziana.
} 
Rufoplaca kaernefeltiana S. Y. Kondr., Lőkös et Hur - Republic of Korea, Gyeongsangbuk-do, Ulleung-gun, Ulleung-eup, Dodong-ri, Dodong Port, Lat.: $37^{\circ} 28^{\prime}$ 59.9" N; Long.: $130^{\circ} 54^{\prime}$ 40.7" E; Alt.: $20 \mathrm{~m}$ a.s.l., on rock, growing together with Rinodina moziana, Caloplaca subconcilians, Squamulea sp., damaged by lichenicolous fungus Bryostigma sp., Phaeophyscia sp., and Aspicilia contorta, Coll.: Kondratyuk, S. Y., Lőkös, L. (162031), 11.07.2016 (KoLRI 040269 sub Rufoplaca). - New localities for the recently described species (Kondratyuk et al. 2017b).

! Zwackhiomyces aff. berengerianus (Arnold) Grube et Triebel - Chile: Cuesta Bvenos ayres, Lat.: $29^{\circ} 35^{\prime} 11.7^{\prime \prime}$ S; Long.: $71^{\circ} 14^{\prime} 52.9^{\prime \prime}$ W; Alt.: $257 \mathrm{~m}$ a.s.l., on rock, on lichen thalli of Follmannia orthoclada. Coll.: Oh, S.-O., Hur, J.-S. (CL130409), 13.11.2013 (KoLRI 020543 sub Follmannia orthoclada, DNA voucher of F. orthoclada SK H94, SK J76). - From Zwackhiomyces berengerianus, parasitic on Mycobilimbia in Europe (Sweden) and North America (Alaska), Chilean material differs in having exciple wall consisting of two distinct layers as well as in different host. - New to South America! Zwackhiomyces aff. berengerianus is for the first time recorded from Follmannia orthoclada.

\section{CONCLUSION}

The further data on new and noteworthy lichen-forming and lichenicolous fungi are in progress and will be published in the nearest future.

\section{$*$}

Acknowledgements - We are thankful to two anonymous reviewers for valuable comments on the manuscript, to Dr Edit Farkas (Vácrátót, Hungary) for her kind help with getting photos of the new taxa described above, and to Dr Konstanze Bensch (the MycoBank team, UK) for nomenclature comments. This work was supported by a grant from the Korean Forest Service Program through the Korea National Arboretum (KNA1-1-22, 17-2), the Korean National Research Foundation (NRF-2017M3A9B8069471, NRF-2018K1A3A1A13087249), the Korean Brain Pool Program (161S-4-3-1659) and the Ministry of Education and Science of Ukraine (M/172-2017, M53/2019 and M30/2020). The research was financially supported by the Ukrainian State Target Scientific and Technical Program for Antarctic Research.

\section{REFERENCES}

Arup, U. (2006): A new taxonomy of the Caloplaca citrina group in the Nordic countries, except Iceland. - Lichenologist 38(1): 1-20. https://doi.org/10.1017/s0024282905005402

Arup, U., Søchting, U. and Frödén, P. (2013): A new taxonomy of the family Teloschistaceae. - Nordic J. Bot. 31(1): 16-83. https://doi.org/10.1111/j.1756-1051.2013.00062.x

Arup, U., Ekman, S., Lindblom, L. and Mattsson, J.-E. (1993): High performance thin layer chromatography (HPTLC), an improved technique for screening lichen substances. Lichenologist 25(1): 61-71. https://doi.org/10.1017/s0024282993000076

Dodge, C. W. (1973): Lichen flora of the Antarctic continent and adjacent islands. - Phoenix Publishing Co., Canaan, New Hampshire, 389 pp.

Hue, A. (1915a): Lichenes novos vel melius cognitos exposuit. - Ann. Mycol. 13: 73-103. 
Hue, A. (1915b): Lichens. - In: Charcot, J. (ed.): Deuxième expédition antarctique francaise (1908-1910). Sciences naturelles: documents scientifiques. Masson, Paris, 202 pp.

Joshi, S., Kondratyuk, S. Y., Crişan, F., Jayalal. U., Oh, S.-O. and Hur, J.-S. (2013): New additions to lichen mycota of the Republic of Korea. - Mycobiology 41(4): 177-182. https:// doi.org/10.5941/myco.2013.41.4.177

Kärnefelt, I. (1989): Morphology and phylogeny in the Teloschistales. - Crypt. Botany 1: 147-203.

Kondratyuk, S. Y. (2015): Agonimia blumii sp. nov. (Verrucariales, lichen-forming Ascomycota), a new taxon from Eastern Asia. - Ukr. Bot. J. 72(3): 246-251. https://doi. org/10.15407/ukrbotj72.03.246

Kondratyuk, S. Y. and Kärnefelt, I. (1997): Josefpoeltia and Xanthomendoza, two new genera in the family Teloschistaceae (Ascomycotina). - Bibl. Lichenol. 68: 19-44.

Kondratyuk, S. Y. and Kärnefelt, I. (2003): Revision of three natural groups of xanthorioid lichens (Teloschistaceae, Ascomycota). - Ukr. Bot. Zh. 60(4): 427-437.

Kondratyuk, S. Y. and Kudratov, I. (2003): Three new Caloplacas from Tajikistan. - Ukr. Bot. Zh. 60(1): 67-70.

Kondratyuk, S. Y., Oxner, A. N. and Khodosovtsev, A. Y. (2004): Caloplaca. - In: Khodosovtsev, A. Y., Kondratyuk, S. Y., Makarova, I. I. and Oxner, A. N. (eds): Handbook of the lichens of Russia. 9. Fuscideaceae, Teloschistaceae. Nauka, Sankt-Petersburg, pp. 38-236.

Kondratyuk, S. Y., Kärnefelt, I., Elix, J. A. and Thell, A. (2007): New species of the genus Caloplaca in Australia. - Bibl. Lichenol. 95: 341-386.

Kondratyuk S. Y., Kärnefelt, I., Elix, J. A. and Thell, A. (2009a): New Caloplaca species from Australia. - Bibl. Lichenol. 99: 259-278.

Kondratyuk, S. Y., Kärnefelt, I., Elix, J. A. and Thell, A. (2009b): Contributions to the Teloschistaceae, with particular reference to the Southern Hemisphere. - Bibl. Lichenol. 100: 207-282.

Kondratyuk, S. Y., Elix, J. A., Kärnefelt, I. and Thell, A. (2012): An artificial key to Australian Caloplaca species (Teloschistaceae, Ascomycota). - Bibl. Lichenol. 108: 141-160.

Kondratyuk, S. Y., Jeong, M.-H., Yu, N.-H., Kärnefelt, I., Thell, A., Elix, J., Kim, J., Kondratiuk, A. S. and Hur, J.-S. (2013a): Four new genera of teloschistoid lichens (Teloschistaceae, Ascomycota) based on molecular phylogeny. - Acta Bot. Hung. 55(3-4): 251-274. https://doi.org/10.1556/ABot.55.2013.3-4.8

Kondratyuk, S. Y., Elix, J. A., Kärnefelt, I. and Thell, A. (2013b): Five new Caloplaca species (Teloschistaceae, Ascomycota) from Australia. - Folia Crypt. Estonica 50: 41-48. https://doi.org/10.12697/fce.2013.50.06

Kondratyuk, S. Y., Jeong, M.-H., Yu, N.-N., Kärnefelt, I., Thell, A., Elix, J. A., Kim, J., Kondratiuk, A. S. and Hur, J.-S. (2014a): A revised taxonomy for the subfamily Caloplacoideae (Teloschistaceae, Ascomycota), based on molecular phylogeny. - Acta Bot. Hung. 56(1-2): 93-123. https://doi.org/10.1556/ABot.56.2014.1-2.10

Kondratyuk, S. Y., Lőkös, L., Tschabanenko, S., Skirina, I., Galanina, I., Oh, S.-O. and Hur, J.-S. (2014b): Caloplaca kedrovopadensis sp. nova and some new lichens from the Primorsky region, Russia. - Acta Bot. Hung. 56(1-2): 125-140. https://doi.org/10.1556/ ABot.56.2014.1-2.11

Kondratyuk, S. Y., Kärnefelt, I., Thell, A., Elix, J. A., Kim, J., Jeong, M.-H., Yu, N.-N., Kondratiuk, A. S. and Hur, J.-S. (2014c): A revised taxonomy for the subfamily Xanthorioideae (Teloschistaceae, Ascomycota), based on molecular phylogeny. - Acta Bot. Hung. 56(1-2): 141-178. https://doi.org/10.1556/abot.56.2014.1-2.12 
Kondratyuk, S. Y., Lőkös, L., Kim, J., Kondratiuk, A. S., Jeong, M.-H., Zarei-Darki, B. and Hur, J.-S. (2014d): Oxnerella safavidiorum gen. et sp. nov. (Lecanoromycetidae, Ascomycota) from Iran (Asia) proved by phylogenetic analysis. - Acta Bot. Hung. 56(3-4): 377-396. https://doi.org/10.1556/abot.56.2014.3-4.13

Kondratyuk, S. Y., Kärnefelt, I., Thell, A., Elix, J. A., Kim, J., Kondratiuk, A. S. and Hur, J.-S. (2015a): Tassiloa, a new genus in the Teloschistaceae (lichenized Ascomycetes). - Graphis Scripta 27(1-2): 22-26.

Kondratyuk, S. Y., Lőkös, L., Kim, J. A., Kondratiuk, A. S., Jeong, M.-H. Jang, S. H., Oh, S.-O. and Hur, J.-S. (2015b): Three new monotypic genera of the caloplacoid lichens (Teloschistaceae, lichen-forming Ascomycetes). - Mycobiology 43(3): 195-202. https:// doi.org/10.5941/myco.2015.43.3.195

Kondratyuk, S. Y., Lőkös, L., Halda, J. P., Haji Moniri, M., Farkas, E., Park, J. S., Lee, B. G., Oh, S.-O. and Hur, J.-S. (2016a): New and noteworthy lichen forming and lichenicolous fungi 4. - Acta Bot. Hung. 58(1-2): 75-136. https://doi.org/10.1556/034.58.2016.1-2.4

Kondratyuk, S. Y., Lőkös, L., Halda, J. P., Upreti, D. K., Mishra, G. K., Haji Moniri, M., Farkas, E., Park, J. S., Lee, B. G., Liu, D., Woo, J.-J., Jayalal, R. G. U., Oh, S.-O. and Hur, J.-S. (2016b): New and noteworthy lichen-forming and lichenicolous fungi 5. - Acta Bot. Hung. 58(3-4): 319-396. https://doi.org/10.1556/abot.58.2016.3-4.7

Kondratyuk, S. Y., Lőkös, L., Park, J.-S., Jang, S.-H., Jeong, M.-H. and Hur, J.-S. (2016c): New Aspicilia species from South Korea proved by molecular phylogeny with a key to the Eastern Asian aspicilioid lichens. - Studia bot. hung. 47(2): 227-249. https://doi. org/10.17110/studbot.2016.47.2.227

Kondratyuk, S. Y., Lőkös, L., Farkas, E., Woo, J.-J. and Hur, J.-S. (2016d): Phaeophyscia esslingeri sp. nov. (Physciaceae, lichen-forming Ascomycota) - a new lichen species from Eastern Asia, with a world-wide key to the hairy species of the genus. - Studia bot. hung. 47(2): 251-262. https://doi.org/10.17110/StudBot.2016.47.2.251

Kondratyuk, S. Y., Lőkös, L., Kim, J. A., Kondratiuk, A. S., Jeong, M.-H., Jang, S. H., Oh, S.-O., Wang, X. Y. and Hur, J.-S. (2016e): Fauriea, a new genus of the lecanoroid caloplacoid lichens (Teloschistaceae, lichen-forming Ascomycetes). - Acta Bot. Hung. 58(3-4): 303-318. https://doi.org/10.1556/ABot.58.2016.3-4.6

Kondratyuk, S. Y., Lőkös, L., Kärnefelt, I., Thell, A., Elix, J. A., Oh, S.-O. and Hur, J.-S. (2016f): Three new Orientophila species (Teloschistaceae, Ascomycota) from Eastern Asia. - Graphis Scripta 28(1-2): 50-58.

Kondratyuk, S. Y., Lőkös, L., Upreti, D. K., Nayaka, S., Mishra, G. K., Ravera, S., Jeong, M.-H., Jang, S.-H., Park, J. S. and Hur, J.-S. (2017a): New monophyletic branches of the Teloschistaceae (lichen-forming Ascomycota) proved by three gene phylogeny. Acta Bot. Hung. 59(1-2): 71-136. https://doi.org/10.1556/034.59.2017.1-2.6

Kondratyuk, S. Y., Lőkös, L., Halda, J. P., Roux, C., Upreti, D. K., Schumm, F., Mishra, G. K., Nayaka, S., Farkas, E., Park, J. S., Lee, B. G., Liu, D., Woo, J.-J. and Hur, J.-S. (2017b): New and noteworthy lichen-forming and lichenicolous fungi 6. - Acta Bot. Hung. 59(1-2): 137-260. https://doi.org/10.1556/034.59.2017.1-2.7

Kondratyuk, S. Y., Lőkös, L., Halda, J. P., Farkas, E., Upreti, D. K., Thell, A., Woo, J.-J., Oh, S.-O. and Hur, J.-S. (2018): New and noteworthy lichen-forming and lichenicolous fungi 7. - Acta Bot. Hung. 60(1-2): 115-184. https://doi.org/10.1556/034.60.2018.1-2.8

Kondratyuk, S. Y., Lőkös, L., Halda, J. P., Farkas, E., Upreti, D. K., Thell, A., Woo, J.-J., Oh, S.-O. and Hur, J.-S. (2019a): New and noteworthy lichen-forming and lichenicolous fungi 8. - Acta Bot. Hung. 61(1-2): 101-135. https://doi.org/10.1556/034.61.2019.1-2.8 
Kondratyuk, S. Y., Lőkös, L., Farkas, E., Jang, S.-H., Liu, D., Halda, J., Persson, P.-E., Hansson, M., Kärnefelt, I., Thell, A. and Hur, J.-S. (2019b): Three new genera of the Ramalinaceae (lichen-forming Ascomycota) and the phenomenon of presence of 'extraneous mycobiont DNA' in lichen associations. - Acta Bot. Hung. 61(3-4): 275-323. https://doi.org/10.1556/034.61.2019.3-4.5

Kondratyuk, S. Y., Lőkös, L., Farkas, E., Jang, S.-H., Liu, D., Halda, J., Persson, P.-E., Hansson, M., Kärnefelt, I., Thell, A., Fačkovcová, Z., Yamamoto, Y. and Hur, J.-S. (2019c): New and noteworthy lichen-forming and lichenicolous fungi 9. - Acta Bot. Hung. 61(3-4): 325-367. https://doi.org/10.1556/034.61.2019.3-4.6

Kondratyuk, S. Y., Lőkös, L., Halda, J., Lee, B. G., Jang, S.-H., Woo, J.-J., Park, J. S., Oh, S.-O., Han, S.-K. and Hur, J.-S. (2019d): Arthonia dokdoensis and Rufoplaca toktoana, two new taxa from Dokdo Islands (South Korea). - Mycobiology 47(4): 355-367. https://doi. org/10.1080/12298093.2019.1688074

Kondratyuk, S. Y., Upreti, D. K., Mishra, G. K., Nayaka, S., Ingle, K. K., Orlov, O. O., Kondratiuk, A. S., Lőkös, L., Farkas, E., Woo, J.-J. and Hur, J.-S. (2020a): New and noteworthy lichen-forming and lichenicolous fungi 10. - Acta Bot. Hung. 62(1-2): 69-108. https://doi.org/10.1556/034.62.2020.1-2.6

Kondratyuk, S. Y., Lőkös, L., Farkas, E., Kärnefelt, I., Thell, A., Yamamoto, Y. and Hur, J.-S. (2020b): Three new genera of the Teloschistaceae proved by three gene phylogeny. Acta Bot. Hung. 62(1-2): 109-136. https://doi.org/10.1556/034.62.2020.1-2.7

Kondratyuk, S. Y., Lőkös, L., Jeong, M.-H., Oh, S.-O., Kondratiuk, A. S. and Hur, J.-S. (2020c): Contribution to molecular phylogeny of lichen-forming fungi 1 . The family Candelariaceae. - Acta Bot. Hung. 62(3-4): 293-307. https://doi.org/10.1556/034.62.2020.3-4.4

Lamb, I. M. (1963): Index Nominum Lichenum, inter annos 1932 et 1960 divulgatorum. - Ronald Press Co., New York, 809 pp.

Liu, D., Wang, L. S., Wang, X. Y. and Hur, J.-S. (2019):. Two new species of the genus Candelariella from China and Korea. - Mycobiology 47(1):40-49. https://doi.org/10.1080/1 2298093.2019.1583785

Lumbsch, H. T., Ahti, T., Altermann, S., Amo de Paz, G., Aptroot, A., Arup, U., Bárcenas Peña, A., Bawingan, P. A., Benatti, M. N., Betancourt, L., Björk, C. R., Boonpragob, K., Brand, M., Bungartz, F., Cáceres, M. E. S., Candan, M., Chaves, J. L., Clerc, P., Common, R., Coppins, B. J., Crespo, A., Dal-Forno, M., Divakar, P. K., Duya, M. V., Elix, J. A., Elvebakk, A., Fankhauser, J. D., Farkas, E., Itati-Ferraro, L., Fischer, E., Galloway, D. J., Gaya, E., Giralt, M., Goward, T., Grube, M., Hafellner, J., Hernández, J. E., Herrera Campos, M. A., Kalb, K., Kärnefelt, I., Kantvilas, G., Killmann, D., Kirika, P., Knudsen, K., Komposch, H., Kondratyuk, S. Y., Lawrey, J. D., Mangold, A., Marcelli, M. P., McCune, B., Messuti, M. I., Michlig, A., González, R. M., Moncada, B., Naikatini, A., Nelsen, M. P., Øvstedal, D. O., Palice, Z., Papong, K., Parnmen, S., Pérez-Ortega, S., Printzen, C., Rico, V. J., Rivas Plata, E., Robayo, J., Rosabal, D., Ruprecht, U., Salazar Allen, N., Sancho, L., Santos de Jesus, L., Santos Vieira, T., Schultz, M., Seaward, M. R. D., Sèrusiaux, E., Schmitt, I., Sipman, H. J. M., Sohrabi, M., Søchting, U., Søgaard, M. Z., Sparrius, L. B., Spielmann, A., Spribille, T., Sutjaritturakan, J., Thammathaworn, A., Thell, A., Thor, G., Thüs, H., Timdal, E., Truong, C., Türk, R., Umaña Tenorio, L., Upreti, D. K., van den Boom, P., Vivas Rebuelta, M., Wedin, M., Will-Wolf, S., Wirth, V., Wirtz, N., Yahr, R., Yeshitela, K., Ziemmeck, F., Wheeler, T. and Lücking, R. (2011): One hundred new species of lichenized fungi: a signature of undiscovered global diversity. - Phytotaxa 18: 1-127. https://doi.org/10.11646/phytotaxa.18.1.1 
Orange, A., James, P. W. and White, F. J. (2010): Microchemical methods for the identification of lichens. - British Lichen Society, London, $101 \mathrm{pp}$.

Øvstedal, D. O. and Lewis Smith, R. I. (2001): Lichens of Antarctica and South Georgia: a guide to their identification and ecology. - Studies in Polar Research, Cambridge University Press, Cambridge, England, 411 pp.

Poelt, J. and Petutschnig, W. (1992): Xanthoria candelaria und ähnliche Arten in Europa. Herzogia 9: 103-114.

Redinger, K. (1938): Restitution und kritische Revision der Flechtengattungen Enterographa Fée und Sclerophyton Eschw. - Feddes Repert. 43: 49-77.

Santesson, R. (1994): Fungi Lichenicoli Exsiccati, Fasc. 7 \& 8 (Nos 151-200). - Thunbergia 6: $1-18$.

Sheard, J. W., Ezhkim, A. K., Galanina, I. R., Himelbrant, D., Kuznetsova, E., Shimizu, A., Stepanchikova, I., Thor, G., Tønsberg, T., Yakovchenko, L. S. and Spribille, T. (2017): The lichen genus Rinodina (Physciaceae, Caliciales) in north-eastern Asia. - Lichenologist 49(6): 617-672. https://doi.org/10.1017/s0024282917000536

Sparrius, L. B. (2004): A monograph of Enterographa and Sclerophyton. - Bibl. Lichenol. 89: $1-141$.

Steiner, J. (1910): Lichenes Persici coll. a cl. Consule Th. Strauss. - Ann. Mycol. 8: 212-245.

Vainio, E. A. (1903): Lichens. - In: de Gerlache de Gomery, A. (ed.): Expédition antarctique Belge. Résultats du voyage du S. Y. Belgica en 1897-1898-1899. Rapports scientifiques. Botanique. J. E. Buschmann, Anvers, 46 pp.

Vainio, E. (1921): Lichenes ab A. Yasuda in Japonia collecti. Continuatio I. - Bot. Mag., Tokyo 35: 45-79.

Vondrák, J., Khodosovtsev, A., Šoun, J. and Vondráková, O. (2012): Two new European species from the heterogeneous Caloplaca holocarpa group (Teloschistaceae). $-\mathrm{Li}$ chenologist 44(1): 73-89. https://doi.org/10.1017/s0024282911000636

Wetmore, C. M. (2003): The Caloplaca squamosa group in North and Central America. - Bryologist 106(1): 147-156. https://doi.org/10.1639/0007-2745(2003)106[0147:tcsgin]2.0.co;2

Wirth, V., Hauck, M. and Schultz, M. (2013): Die Flechten Deutschlands. - Verlag Eugen Ulmer, Stuttgart, 1144 pp.

Zahlbruckner, A. (1924): Die Flechten der Juan-Fernandez-Inseln. - In: Skottsberg, C. (ed.): The natural history of Juan Fernandez and Easter Island. II, pp. 315-498.

Open Access statement. This is an open-access article distributed under the terms of the Creative Commons Attribution-NonCommercial 4.0 International License (https://creativecommons.org/licenses/by-nc/4.0/), which permits unrestricted use, distribution, and reproduction in any medium for non-commercial purposes, provided the original author and source are credited, a link to the CC License is provided, and changes - if any - are indicated. 